\title{
THE HEPATICAE OF THE YAMAL PENINSULA, WEST SIBERIAN ARCTIC
}

\author{
ПЕЧЕНОЧНИКИ ПОЛУОСТРОВА ЯМАЛ, ЗАПАДНОСИБИРСКАЯ АРКТИКА
}

\author{
ALEXEY D. POTEMKIN ${ }^{1}$
}

А. Д. ПОТЕМКИН ${ }^{1}$

Abstract

Hepatic flora of Yamal Peninsula includes 121 species, 2 subspecies, 22 varieties and 11 forms. The conspect includes informatoion about species distribution within the peninsula, their habitat preferances, associated species, and for selected species also taxonomic comments. There is described Gymnocolea fascinifera Potemk sp. nov. and new combinations suggested for Cephaloziella divaricata var. polystratosa (Schust. \& Damsh.) Potemk. comb. nov. (Cephaloziella byssacea (A.Roth) Warnst. var. polystratosa Schust. \& Damsh. and also for two forms in Barbilophozia.

Резюме

Флора печеночников полуострова Ямал насчитывает 121 вид, 2 подвида, 22 разновидности и 11 форм. В прнводимом конспекте подробно указано распространение вндов на полуострове, описаны их местообитания, сопутствующие виды, a для некоторых - даны также таксономические заметки. Описан новый вид, Gymnocolea fascinifera Potemk. sp. nov. предложены новые хомбинации для Cephaloziella divaricata var. polystratosa (Schust. \& Damsh.) Potemk. comb. nov. (Cephaloziella byssacea (A.Roth) Warnst. var. polystratasa Schust. \& Damsh. и дия двух форм в роде Barbilophozia.

\section{INTRODUCTION}

\section{Historical BaCkground AND MATE- RIALS}

The report represents the first attempt to bring together in one place and reconsider all available information, published and unpublished, about the Hepaticae of the Yamal Peninsula. Until the last decade, our knowledge concerning this peculiar Arctic region was almost noneexistent. A few reports (Arnell 1918; Ladyzhenskaja 1971; Andrejeva 1981), contain mostly fragmentary data on about 30 species, and several geobotanical papers mention some common hepatics.

The most important contribution to the study of the Yamal flora has been made by Olga V. Rebristaya, the leader of the Yamal group of Polar Expedition of the V. L. Ko- marov Botanical Institute, St. Petersburg. Besides of study of vascular plants, she and her colleagues collected bryophytes and lichens everywhere they worked from 1973 to 1983 , and in 1990 and 1992. These materials form the basis for the reports of A. L. Zhukova and $O$. V. Rebristaya $(1986,1987)$ on the Hepaticae of Belyy Island and the Matyuiyaha (Matyuiyakha) River Region and for my studies of Yamal liverworts (Gribova \& Potemkin 1988; Potemkin 1988, 1989, 1990 a, b, c, d, e, 1992 a, b, 1993 a, b, Czernyadjeva \& Potemkin 1993, etc.). Moreover my own collections (July, Aug. 1988) and collections of L. I. Mel'tzer and A. P. Popov (Institute of Problem of Development of North, Tyumen) madë in 1987, 1989 and 1990 were used for the study. Totally about 15000 specimens of bryophytes and lichens were investigated for hepatics.

1 - Russia 197376 St.-Petersburg, Prof. Popova str., 2, Botanical Institute of Russian Acad. Sci. (Poccus 197376 Санкт-Петербург, проф. Попова, 2, Ботанический институт РАН). 
Table 1. Localities of Yamal, where Hepaticae have been collected

\begin{tabular}{|c|c|c|c|}
\hline $\mathrm{N}^{\mathrm{C}}$ & Locality and its abbreviation (in italics) & latitude & longitude \\
\hline 1 . & SE part of Belyy Island & $73^{\circ} 15^{\prime} \mathrm{N}$; & $71^{\circ} 30^{\prime} \mathrm{E}$ \\
\hline & Middle Khabeiyaha River & $72^{\circ} 25^{\prime} \mathrm{N}$; & $72^{\circ} 10^{\prime} \mathrm{E}$ \\
\hline & Upper Tambey River & $71^{\circ} 45^{\prime} \mathrm{N}$; & $70^{\circ} 30^{\prime} \mathrm{E}$ \\
\hline & Lower Tirvyyaha River & $71^{\bullet} 35^{\prime} \mathrm{N}$; & $71^{\circ} 30^{\prime} \mathrm{E}$ \\
\hline 5. & Basin of right tributary of Kharasavey River - Silyaha River & $71^{\circ} 10^{\prime} \mathrm{N}$; & $67^{\circ} 05^{\prime} \mathrm{E}$ \\
\hline & Middle Matyuiyaha River & $70^{\circ} 55^{\prime} \mathrm{N}$; & $70^{\circ} 20^{\prime} \mathrm{E}$ \\
\hline & Upper Tiutey River & $70^{\circ} 50^{\prime} \mathrm{N}$; & $69^{\circ} 45^{\prime} \mathrm{E}$ \\
\hline & Middle Venuieuo River & $70^{\circ} 40^{\prime} \mathrm{N}$; & $71^{\circ} 00^{\prime} \mathrm{E}$ \\
\hline 9. & Geological station Bovanenkovo & $70^{\circ} 20^{\prime} \mathrm{N}$; & $68^{\circ} 20^{\prime} \mathrm{E}$ \\
\hline 10 & Interfluve of Tomboiyaha and Syoyaha Rivers (Tomboitosyo) & $70^{\circ} 15^{\prime} \mathrm{N}$; & $69^{\circ} 40^{\prime} \mathrm{E}$ \\
\hline 11 & Neromayaha River Basin & $70^{\circ} 10^{\prime} \mathrm{N}$ & $69^{\circ} 10^{\prime} \mathrm{E}$ \\
\hline 12 & Middle Syoyaha River, norther of Mantyto Lake & $70^{\circ} 05^{\prime} \mathrm{N}$ & $72^{\circ} 10^{\prime} \mathrm{E}$ \\
\hline 13 & $15 \mathrm{~km}$ NW of Marre Sale Polar Station & $69^{\circ} 50^{\prime} \mathrm{N}$; & $67^{\circ} 10^{\prime} \mathrm{E}$ \\
\hline 14 & Saletayaha River Basin & $69^{\circ} 45^{\prime} \mathrm{N}$; & $68^{\circ} 40^{\prime} \mathrm{E}$ \\
\hline 15 & Lower Yuribeitoyaha River & $69^{\circ} 45^{\prime} \mathrm{N}$ & $72^{\circ} 25^{\prime} \mathrm{E}$ \\
\hline 16 & Middle Sebayaha River & $69^{\circ} 37^{\prime} \mathrm{N} ;$ & $69^{\circ} 27^{\prime} \mathrm{E}$ \\
\hline 17 & Lower Khakhayayaha River & $69^{\circ} 35^{\prime} \mathrm{N}$; & $67^{\circ} 35^{\prime} \mathrm{E}$ \\
\hline 18 & Middle Lyakkotosyo River & $69^{\circ} 30^{\prime} \mathrm{N}$; & $71^{\circ} 25^{\prime} \mathrm{E}$ \\
\hline 19 & Lower Khutyyaha River & $69^{\circ} 45^{\prime} \mathrm{N}$; & $70^{\circ} 30^{\prime} \mathrm{E}$ \\
\hline 20 & Middle Khevesyo River & $68^{\circ} 35^{\prime} \mathrm{N}$; & $73^{\circ} 20^{\prime} \mathrm{E}$ \\
\hline 21 & Middle Yuribey River & $68^{\circ} 25^{\prime} \mathrm{N} ;$ & $72^{\circ} 10^{\prime} \mathrm{E}$ \\
\hline 22 & Lower Laptayaha River (Mys Kamennyy) & $68^{\circ} 20^{\prime} \mathrm{N}$; & $73^{\circ} 15^{\prime} \mathrm{E}$ \\
\hline 23 & Erkutayaha River Basin, $10 \mathrm{~km}$ to $\mathrm{N}$ from Kharangyneto Lake & $68^{\circ} 15^{\prime} \mathrm{N}$; & $69^{\circ} 55^{\prime} \mathrm{E}$ \\
\hline 24 & Lower Eryaha River & $68^{\circ} 10^{\prime} \mathrm{N}$; & $72^{\circ} 50^{\prime} \mathrm{E}$ \\
\hline 25 & Upper Khadytayaha River & $67^{\circ} 35^{\prime} \mathrm{N}$; & $70^{\circ} 25^{\prime} \mathrm{E}$ \\
\hline
\end{tabular}

\section{Methodological Remarks}

Taking into account the great malleability of arctic liverworts and the importance of oil-bodies characteristics for their determination, I tried to identify them alive when it was possible. Only complex analysis of variability of morphological features, data on oilbodies and ecological conditions made it possible to form a notion about specific criteria of many species. Absence of data on oil-bodies of some taxa of Lophozia, Scapania, Riccardia, Chiloscyphus, etc. keeps some problems still insoluble. For the analysis of variability of Yamal hepatics see Potemkin (1990b).

3. Definttion of Yamal and PhysioGRAPHIC REMARKS

Yamal Peninsula is situated in the north-western part of the West-Siberian
Lowland and extends from $66^{\circ} 50^{\prime}$ to $73^{\circ}$ $30^{\prime} \mathrm{N}$ and from $66^{\circ} 45^{\prime}$ to $73^{\circ} 30^{\prime} \mathrm{E}$, occupying about $112000 \mathrm{~km}^{2}$ of territory (Sisko 1977).

Yamal is considered here in the narrow sense, i.e., its southern limit is the southern boundary of the peninsula (some authors also classify southern territories adjacent to the peninsula as Yamal). At the same time I classify here under Yamal its northernmost part, Belyy Island, which has the same genesis and is separated from the peninsula only by the shallow Strait of Malygin. Places were collections have been made are in Table 1 and Fig. 1.

Yamal is unique in respect of its physiographic peculiarities and as the youngest Arctic region (Rebristaya 1989). The lowland landscape, absence of rocky outcrops, predominantly oligotrophic, usually acid, rar- 


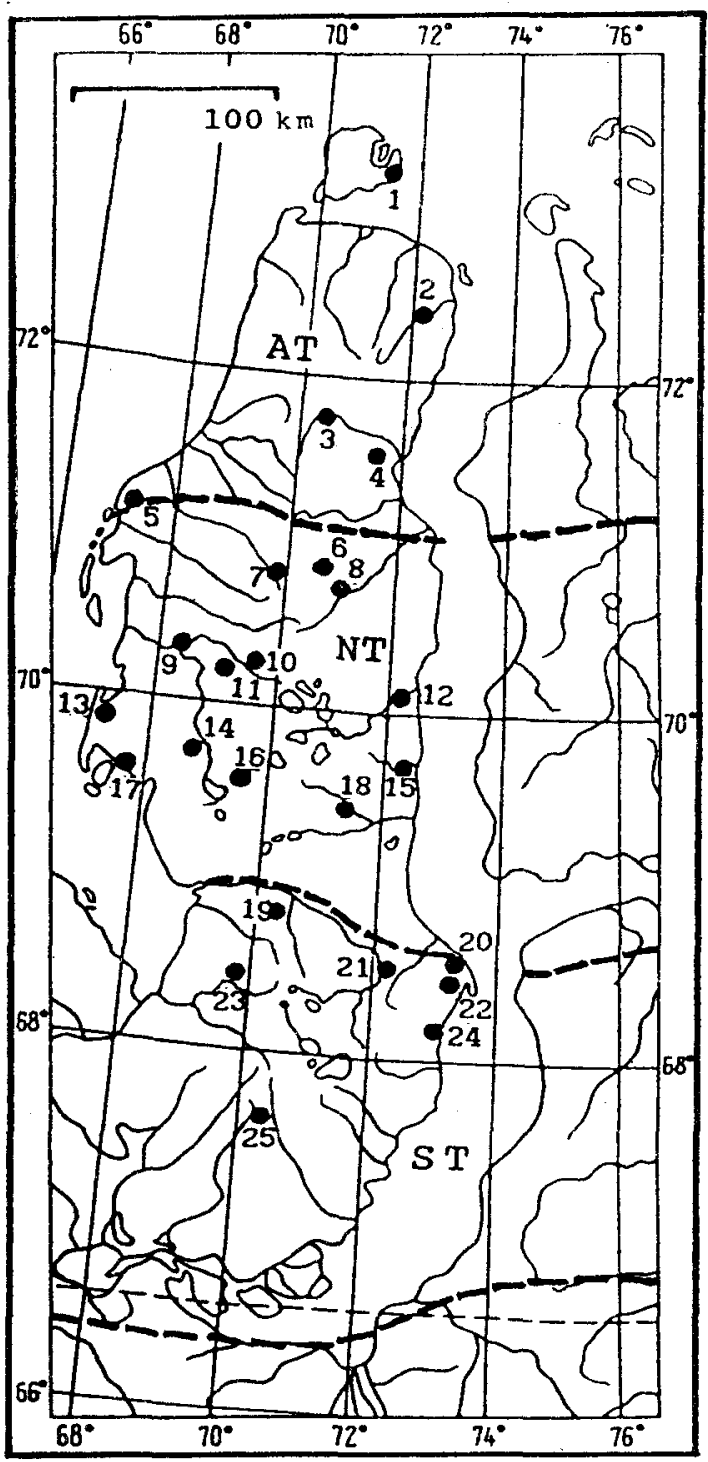

Fig. 1. Cited localities of hepatic collections (see Tab. 1). AT - Arctic tundra, NT - northern hypoarctic tundra, ST - southern hypoarctic tundra.

ely neutral soils together with the rigorous climate and young age of the region cause the poverty of the Yamal flora and the formation of rather monotonous tundra vegetation on the peninsula. According to Yurtsev \& al. (1978), the tundra zone of the Yamal Peninsula is divided into three subzones, the southern hypoarctic, northern hypoarctic, and arctic tundras (Fig. 1).

\section{AKNOWLEDGEMENTS}

I express my sincerest thanks to Drs. A. L. Zhukova and O. V. Rebristaya for drawing my attention to the need for investigation of Yamal hepatics and to Drs. O. V. Rebristaya, S. A. Gribova, I. V. Czernyadjeva, V. V. Golubkov and E. N. Andrejeva, who provided numerous collections of Yamal bryophytes and lichens for my use. I am indebted to Prof. R. M. Schuster for the gift of specimens of Lophozia rubrigemma and Barbilophozia hyperborea; to the Directors and Curators of the following Herbaria for the loan of material in their care: $S, F$, H, TRH, NICH; to Prof. S. K. Tcherepanov for nomenclatural assistance and to Dr. N. N. Zabinkova for the Latin translation of the description of Gymnocolea fascinifera. I am also very grateful to Mrs. O. V. Khitun, who organized my work in Yamal in 1988. Dr. B. M. Murray is cordially thanked for revising the English language and some valuable comments on the manuscript.

\section{SYSTEMATIC ACCOUNT}

The hepatic flora of the Yamal Peninsula is rather poor. 121 species with 2 subspecies, 22 varieties and 11 forms applied to 39 genera, 20 families and 3 orders, Jungermanniales, Metzgeriales and Marchantiales, are known for the peninsula. The list, which is based on detailed analysis of a huge number of collections should be rather complete. On the other hand, addition of mostly rare to Yamal, temperate, basiphillous and mountain species as well as taxa of such problematic groups as Lophozia, Scapania and Riccardia, which need an investigation based on living plants, is quite possible.

In the following conspect the sequence of taxa follows Konstantinova \& al. (1992). Synonyms are listed only (1) when the name of a taxon used here is little-known and (2) to emphasize the author's opinion on synonymy of certain taxa. For taxa which have been erroneously reported for Yamal under other names, these names are noted with reference to corresponding papers. Frequency of taxa is noted for each locality 
or, for taxa with similar frequency in all localities of a subzone, for each subzone. The following scale of frequency is used for localities where 300 or more specimens were collected: if a taxon was found in $1-2$ specimens - I; 3-6 - II; 7 -15 - III; in more than 15 specimens from similar habitats - IV; in more than 15 specimens from different habitats - V. For comparatively poorly investigated places, only the number of collected specimens is listed in Arabic numerals. Literature references are given only for reports not confirmed by specimens, or when there is no collection of a taxon except the published one. For names of subzones the following abbreviations are used: AT (Arctic tundra), NT (northern hypoarctic tundra) and ST (southern hypoarctic tundra).

Characteristic habitats and presence of sexual and asexual reproduction devices are noted for each taxon.

\section{ORDER METZGERIALES Chalaud CODONIACEAE Klinggr.}

FOSSOMBRONIA Raddi

Fossombronia alaskana Steere \& H. Inoue

ST: Khevesyo I, Er'yahe I.

On bare wet loamy soil, associated with Jungermannia polaris, J. obovata, Riccia sorocarpa subsp. arctica, Cephaloziella arctica, Blepharostoma, etc. With mature capsules. Westernmost report for Eurasia. Previously known from Alaska (Steere \& Inoue 1974), West Greenland (Mogensen \& Brassard 1978) and Chukotka (Afonina \& Duda 1983).

Yamal plants of Fossombronia alaskana differ somewhat from American ones (Steere \& Inoue 1.c.; Schuster 1992a). Stems thinner, (8)9-11(12) cells high; width/length leaf ratio more variable, from 1:0.65 - 0.90 to (in the rare mod. angustifolia) $1: 1.0-1.4$; median cells and spores larger, 30 $45(60) \times 28$ - 34(40) mkm and $34-42 \mathrm{mkm}$ respectively; greater variability of number of lamellae intersecting spore margin, (2326) 28 - 32(34); elaters occasionally thinner, 2-spiral (5)6 - $8.5 \mathrm{mkm}, 3$-spiral - 8.5 - 9 $\mathrm{mkm}$ in diam. The only seta has been found
On cross section it is only 5 - 6 cells in diam. A development of perianth lamellae is extremely variable. In Yamal plants lamellae are mostly slightly developed and occasionally impossible to find on the surface of perianths with mature capsules. When capsules and perianths are absent this species may be confused with Lophozia grandiretis, especially var. parviretis Schust. It differs however by the constant absence of gemmae, invariably deep purple rhizoids, position of gametangia, thinner cell walls and, as a consequence, more delicate texture.

\section{PELLIACEAE Klinggr.}

\section{Pelun Raddi}

Pellia neesiana (Gott.) Limpr.

ST: Khutyyaha III, Khevesyo III, Er'yaha II.

In bogs with flowing water, flood plain willow stands, and once on bare soil in spotty tundra. Male and female plants occur rather often.

\section{ALLISONIACEAE (Schust. ex Grolle) Schljak.}

\section{Calycularia Mitt.}

Calycularia laxa Lindb. et $\mathrm{H}$. Arnell

AT: Belyy I, Khabeiyaha III, Tambey III, Kharasavey II; NT: Matyuiyaha I, Neromaysha I, Manty to II, Khakhayayaha I; ST: Khutyyaha I, Khevesyo III, Er'yaha II.

On thinly turfed and bare, steep, often nival, slopes; in lichen tundras; on peat outcrops; on spots of bare soil in different types of tundra; occasionally in sedge-moss bogs. Male and female plants frequent but perianths and sporophytes develop rarely. Westernmost reports for Eurasia. The record on Belyy Island is the northernmost on the globe.

Sterile and female plants of Calycularia laxa are sometimes confused with Pellia. They differ from all species of Pellia by ventral scales, which are $2-4(5)$ cells wide at base and to 10 cells long. Among the regional species of Pellia only $P$. endiviifolia (Dicks.) Dum. develops rather long ventral slime hairs but they are uniseriate and shorter than ventral scales of Calycularia. Moreover $C$. laxa and $P$. endiviifolia are very different in ecological behaviour: the former is 
acidophilous, while the latter is basiphilous. Confusing of female plants of $C$. laxa with Pellia is sometimes possible, because of female scales are very thin, hair-like and inconspicuous, having similar with thallus pigmentation (see also Potemkin 1990a).

PALLAVICINIACEAE Migula

\section{MOERCKIA Gott.}

Moerckia blyttii (Moerck) Brockm.

ST: Khutyyaha I (Andrejeva 1981)(!).

In moss-lichen tundra, small groups of plants among lichens.

\section{BLASIACEAE Klinggr.}

\section{Blasia L.}

\section{Blasia pusilla $\mathrm{L}$.}

NT: Saletayaha 1, Khakhayayaha I; ST: Khytyyaha II, Khevesyo II, Er'yaha II.

On bare wet loamy soil on banks of brooklets, rivers and lakes. Reproduction mostly by scale-like gemmae, very rarely by discoid gemmae in "bottles".

Plants of exposed sites often develop purplish pigmentation and conspicuous white lines along the midrib and its branches which give them a very peculiar appearance. The white lines are caused, according to Macvicar (1926:77), by a deposit of calcium oxalate. At the base of robust plants there are numerous white lines going from the branches. Cross section of old parts of such plants looks septate, i.e. with thick parts with canals filled up by calcium oxalate and thin ones without them. The purplish pigmented phases often develop purplish scale-like gemmae. Secondary pigmentation, however, has not been reported before for the gemmae of Blasia. Schuster (1988: 235) stressed that even in purplish plants the gemmae are always bright green.

\section{ANEURACEAE Klinggr.}

ANEURA Dum.

\section{Aneura pinguis (L.) Dum. var. pinguis}

AT: Belyy 1, Khabelyaha I; NT: Matyulyaha I, Bovanenkovo 2, Neromayaha I, Khakhayayaha I; ST: Khutyyaha II, Khevesyo II, Er'yaha II.

On spots in different types of spotty moss tundras, on loamy slopes, occasionally in bogs. Male and female plants frequent, but plants with mature capsules rare.

Aneura pinguis var. denticulata Nees

ST: Khutyyaha \& Er'yaha (Andreeva 1981).

In homogenous sedge (Carex stans) bogs with flowing water.

\section{Riccardia S. Gray}

Since all specimens of Riccardia have been studied in a dead state, i.e. without any data on their oil-bodies, it is difficult or impossible to identify taxa of this genus correctly (Potemkin 1991). As a consequence, all species are listed under the sign "cf.".

Riccardia cf. chamaedrifolia (With.) Grolle ST: Khutyyaha I.

In sedge-Sphagnum tussock-pool bog, on tussock among Sphagnum. Plants monoicous, with immature calyptral perigynia.

In the Arctic this species is inseparable from the recently described Riccardia latifrons subsp. arctica Schust. \& Damsh. This arctic subspecies of $R$. latifrons is characterized by the same morphological variability and ecological behaviour and differs from $R$. chamaedrifolia only in the absence of oilbodies (Schuster 1987).

It is thus possible that the collections seen are $R$. latifrons subsp. arctica (which has not been reported for Eurasia before).

Riccardia cf. latifrons (Lindb.) Lindb.

NT: Tomboitosyo I, Khakhayayaha I; ST: Khutyyaha I, Khevesyo I.

In moss tundras and sedge-Sphagnum willow stand, at base of willow on mineral soil.

ORDER JUNGERMANNIALES Klinggr.

TRICHOCOLEACEAE Nakai

Subfam. TEMNOMOIDEAE Schust.

Pseudolepicolea Fulf. \& J. Tayl.

Pseudolepicolea fryei (H. Perss.) Grolle \& Ando

AT: Belyy II, Tambey II; NT: Matyulyaha II, Bovanenkovo I, Khakhayayaha I; ST: Er'yaha II, near Khadytayaha (Ladyzhenskaja 1971).

On Sphagnum tussocks in bogs, associated mostly with Blepharostoma trichophyllum var. brevirete.

The species is usually represented by mod. densifolia-colorata. Mod. parvifolia-laxifoliaviridis was found only once (Belyy). 
Subfam. BLEPHAROSTOMATOIDEAE Grolle

BlephaRostoma (Dum.) Dum.

Blepharostoma trichophyllum (L.) Dum. var. trichophyllum

NT: Neromayaha II, Khakhayayaha I.

In nival tundra (with perianths), on top of watershed among lichens, on willow trunk.

Blepharostoma trichophyllum var. brevirete Bryhn \& Kaal. (B. trichophyllum var. trichophyllum auct. non (L.) Dum. - Andrejeva 1981).

AT V; NT: Matyuiyaha IV, Tiutey 6, Venuieuo 2, Bovanenkovo 5 , Tomboitosyo $\mathrm{V}$, Neromayaha $\mathrm{V}$, Manty to $\mathrm{V}$. Marre Sale 11 , Yuribeitoyaha $V$, Sebayaha 3 , Khakhayayaha IV, Lyakkotosyo III; ST: Khutyyaha IV, Khevesyo V, Yuribey 4, Laptayaha V, Kharangyneto 2, Er'yaha III, Khadytayaha 2.

Most common in diverse wet tundras with comparatively rich soils. Rarely with perianth and mature capsules. Plants are usually monoicous, only exceptionally dioicous (in Lyakkotosyo male plants were found).

Plants of this variety vary considerably in size, density of leaves, width of cortical cells $(20-31(40) \mathrm{mkm})$, width/length ratio of leaf cells, shape and size of apical cells of leaf segments. On spots in spotty tundra the phenotypes with short leaf segments composed of isodiametric cells occur. Sporadically plants with 4-5 - lobed leaves and 4 - lobed underleaves were found. Individual leaf segments of such plants are branched. Despite great malleability, var. brevirete in Yamal is almost always distinguished from the typical variety by its not bulging septae, separating the cells of leaf segments.

\section{ANTHELIACEAE Schust.}

ANTHElia (Dum.) Dum.

Anthelia juratzkana (Limpr.) Trev. f. juratzkana

AT: Belyy IV, Khabeiyaha III, Tambey III, Kharasavey III; NT: Matyuiyaha III, Tiutey 1 . Tomboitosyo I, Neromayaha IV, Manty to I, Saletayaha 4, Yuribeitoyaha I, Khakhayayaha III, Lyakkotosyo I; ST: Khutyyaha III, Khevesyo V, Laptayaha IV, Er'yaha III, Khadytayaha 1 .

In wet spotty tundras, on nival slopes. Often with perianths and mature capsules.

Anthelia juratzkana f. elongata Joerg.

AT: Belyy I; NT: Neromayaha I

In spotty tundras on sandy soil, occasionally together with f. juratzkana.
JUNGERMANNIACEAE Reichenb.

Subfam. LOPHOZIOIDEAE Macv.

TETRALOPHOZia (Schust.) Schljak.

Tetralophozia setiformis (Ehrh.) Schljak.

AT: Belyy I, Khabeiyaha I, Tambey III; NT: Matyuiyaha II, Khakhayayaha I; ST: Laptayaha I.

In diverse tundras on sandy soil.

In Belyy and Matyuiyaha the plants of mod. parvifolia-densifolia-(subdensifolia)-viridis (subcolorata) were found. They have (2) 3 - lobed leaves with smaller median and especially ventral lobes and larger dorsal ones. In leaf form these plants resemble Chandonanthus birmensis Steph., differing from it in subtransverse leaf insertion, cell net, etc. They may be confused also with Barbilophozia quadriloba, which have, however, more symmetric, less deeply divided leaves and a rough cuticle.

BARBILOPHOZIA Loeske sensu lato

Subgen. ORTHOCAULIS (Buch) Buch

Barbilophozia quadriloba (Lindb.) Loeske f. quadriloba

AT: Belyy I, Khabeiyaha I, Tambey II, Kharasavey I; NT: Matyuiyaha I, Tomboitosyo I, Marre Sale 1 , Saletayaha 2, Yuribeitoyaha III, Lyakkotosyo I; ST: Laptayaha I, Er'yaha I.

In diverse tundras with comparatively rich soils.

Barbilophozia quadriloba f. glareosa (Joerg.) Potemk. [Bot. Zhurn. 75(12):1744, 1990]

AT: Belyy II, Tambey I, Kharasavey II; NT: Bovanenkovo I, Neromayaha II, Yurbeitoyaha II, Khakhayayaha I; ST: Khevesyo III.

In diverse tundras, probably in less favorable conditions than the type form.

Barbilophozia quadriloba f. cephalozielloides (Schust.) Potemk. [Novosti Sist. Nizsh. Rast. 28:150, 1992]

AT: Belyy I.

In herb-grass-willow-moss tundra, on bare soil, individual shoots in association with Scapania zemljae, Lophozia heterocolpos var. harpanthoides, Barbilophozia quadriloba f. glareosa, Odontoschisma macounii, Jungermannia polaris, Cephalozia pleniceps, Cephaloziella arctica, Blepharostoma trichophyllum var. brevirete, etc. 


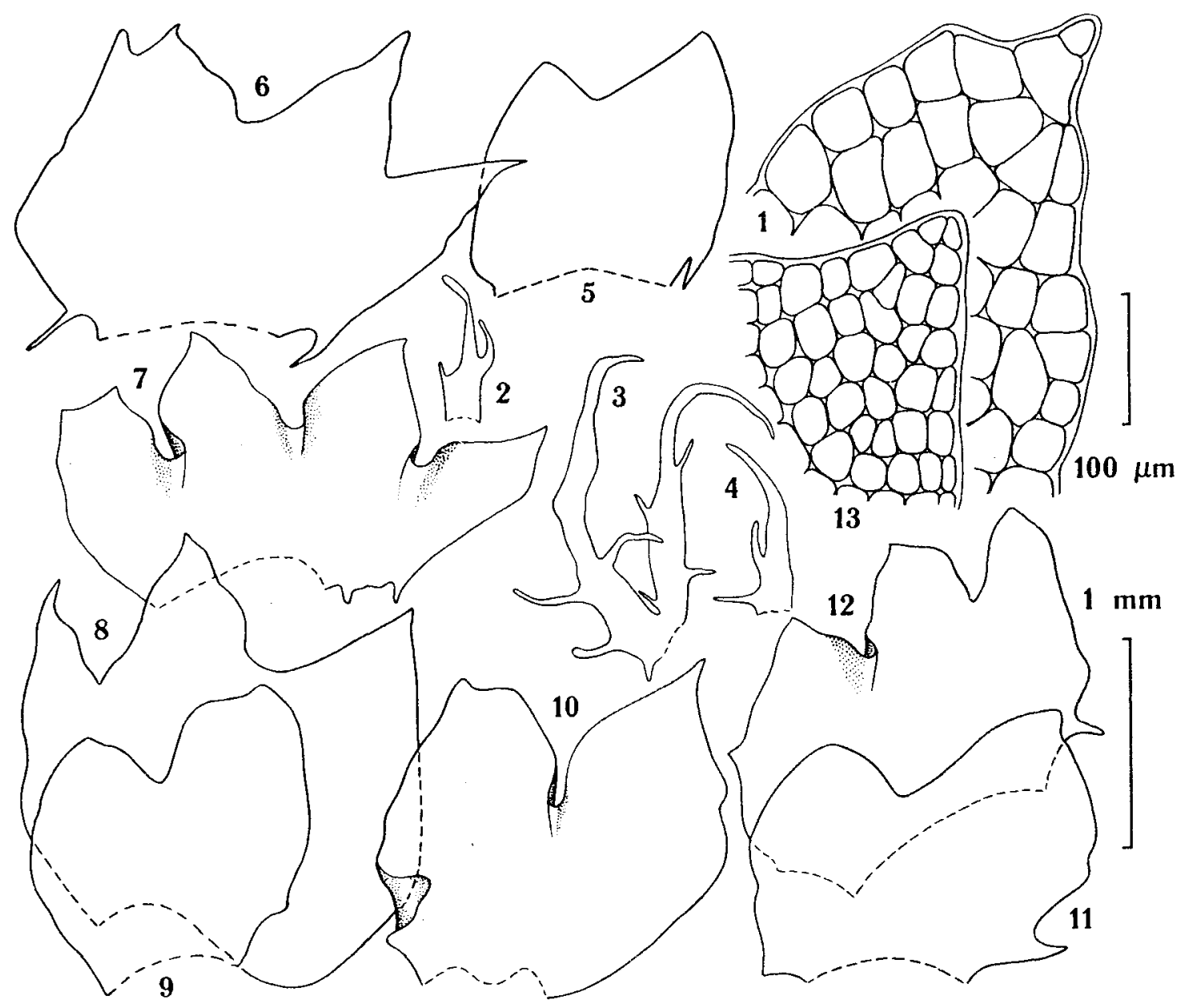

Fig. 2. Barbilophozia hyperborea (1-12) and B. quadriloba (13). 1, 13 - Apexes of lobes; 2-4 - Underleaves; 5-12 Leaves. Scale bars: $100 \mathrm{mkm}$ - for 1,$13 ; 1 \mathrm{~mm}$ - for 2-12. All from Khutyyaha (After Potemkin 1992a).

Barbilophozia hyperborea (Schust.) R. Stotl. \& B. Stotl. ex Potemk. [Novosti Sist. Nizsh. Rast. 28: 148, 1992] (Fig. 2).

AT: Kharsavey I; NT: Matyuiyaha I, Tiutey I, Neromayaha III, Saletayaha 2, Khakhayayaha II; ST: Khutyyaha I, Khevesyo I.

In dwarf shrub-(herb-) moss and sedgemoss tundras, on brook banks, mostly on weakly turfed soil. Once (Neromayaha) with perianths. For details and differentiation see Potemkin (1992a).

Barbilophozia kunzeana (Hueb.) K. Muell. f. kunzeana

AT: Belyy I, Khabeiyaha I, Tambey II, Kharasavey II; NT: Matyuiyaha $\mathrm{V}$, Tiutey 3 , Venuieuo $I$, Bovanenkovo 3. Tomboitosyo V, Neromayaha III, Marre Sale 2, Saletayaha 1 , Yuribeitoyaha II, Sebayaha 2, Khakhayayaha
II, Lyakkotosyo II; ST: Khutyyaha V, Khevesyo V, Yuribey 3, Laptayaha IV, Kharangyneto 5, Er'yaha IV, Khadytayaha 3 .

In diverse moss tundras, bogs, peat outcrops, occasionally in late snow areas. Very rarely with perianths and mature capsules, sometimes with gemmae. Gemmae predominantly rhombic, $10-17 \times 18-23$ (31) $\mathrm{mkm}$, varying in color from green and yellowish to brown, red brown and, occasionally, deep purple (found in plants of mod. parvifoliacolorata, Matyuiyaha). Leaf cells of gemmiferous shoots contain (6) 8 - 13(15) oil-bodies and of shoots, not developing gemmae, (3) 4 6 oil-bodies (found in plants from Khevesyo). Occasionally, gemmiparous leaves have a very rough, Barbilophozia quadriloba-like 
cuticle (as in plants from Mantyto).

The variability of the species was described in detail by Schuster (1969). Some phenotypes, however, have not been found before. Among them: 1) plants with flat, comparatively narrow, not folded, appressed to stem leaves with not reflexed sinus and small lanceolate underleaves; 2) plants similar to "f. plicata", differing in the absence or very weak development of amphigastria.

Barbilophozia kunzeana f. acuta (Schust.) Potemk. comb. nov. (Lophozia kunzeana f. acuta Schust. Hep. Anth. N. Am. 2:299, 1969)

NT: Neromayaha I.

In dwarf shrub moss-lichen tundra, in Polytrichum-lichen mat.

Barbilophoxia kunzeana f. rotundiloba (Schust.) Potemk. comb. nov. (Lophozia kunzeana var. rotundiloba Schust., in Schuster \& al., Natl. Mus. Canada Bull. 164:24, 1959)

AT: Kharasvey 1.

In moss-sedge bog, among Sphagnum.

Plants green, very large, 10 - $15 \mathrm{~mm}$ long and $1-1.5 \mathrm{~mm}$ wide, with oblique inserted, distinctly dorsally decurrent 2-3-lobed wide leaves $(2$ - lobed leaves $840-1340$ mkm wide and $730-1000$ mkm long; 3 lobed leaves $1060-1400 \mathrm{mkm}$ wide and 810 - $950 \mathrm{mkm}$ long), near ventral and occasionally dorsal base with $1-2$ teeth or short cilia; sinuses acute, gamma-like, with strongly reflexed margins, descending 0.37 0.50 to $0.57-0.62(0.64)$; lobes mostly more or less divergent, wide ovate, rotund, obtuse, rarely acute; underleaves very large, 500 $600(890) \mathrm{mkm}$ long, bifid almost to the base, often with 1 - 2 cilia on outer margins and, occasionally, 1 cilium per inner margin; underleaf sinus often reflexed; marginal leaf cells $14-20$ mkm, median - 20 25 (28) x $19-23 \mathrm{mkm}$; cuticle from faintly to distinctly striolate-papillose, occasionally with rather large flat papillae.

Yamal plants of $f$. rotundiloba differ from American ones in the more lax leaf position and predominantly bilobed very large underleaves with cilia on outer and inner margins. In the deeply bifid leaves, large bifid underleaves and sporadically coarsely papil- lose cuticle these plants resemble Barbilophozia quadriloba, differing in the wide ovate lobes with mostly obtuse apex, pure green color and larger size. On the other hand they may be confused with $B$. floerkei (F. Web. \& Mohr) Loeske, which has the same pigmentation, size, very large underleaves with cilia on inner margins of lobes and gibbous leaf sinuses. $B$. kunzeana f. rotundiloba is distinguished from this species in the predominantly bilobed leaves with considerably deeper sinuses and mostly obtuse lobes.

Barbilophozia kunzeana f. wenzelioides (Schust.) Potemk. [Novosti Sist. Nizsh. Rast. 29:167, 1993]

NT: Bovanenkovo 1.

In weakly polygonal dwarf shrub lichenmoss tundra, among Sphagnum. With gemmae.

Barbilophozia binsteadii (Kaal.) Loeske (Orthocaulis attenuatus auct. non (Mart.) Evans - Andrejeva 1981; Zhukova \& Rebristaya 1986)

AT IV - V; NT IV - V; ST V.

In diverse wet moss tundras and bogs, usually among Sphagnum, Dicranum, Aulacomnium, Polytrichum, considerably more rarely among lichens, sporadically individual shoots on bare soil. Occasionally with gemmae which, as a rule, develop on plants of mod. densifolia-colorata, only once on plants of mod. laxifolia-viridis. Male and perianth bearing plants occur rarely.

The species is very malleable ecologically and morphologically. Occasionally it resembles very much in some important diagnostic features Barbilophozia attenuata (Mart.) Loeske and $B$. atlantica. In such cases only complex analysis of all diagnostic criteria makes it possible to positively identify the species (cf. Schuster 1969).

In the course of investigation of the species in Yamal some paradoxical manifestations of its variability were found: 1) not only neighbour plants (Schuster 1969) but different leaves of the same shoot may have cell net of Barbilophozia attenuata- and $B$. binsteadiitypes, i.e. with marginal cells (13)14 - 
17(18) mkm and median 16-18 x 17-23 mkm with small concave-sided trigones or with marginal cells $19-21 \mathrm{mkm}$ and median - $18-20 \times 20-23$ mkm with large nodulose often confluent in lobes trigones; 2) leaves are not always with 3 narrow lobes, occasionally the plants with subtransverse inserted wide $3(4)$ - lobed $B$. atlantica-like leaves with shallow sinuses (to $0.35-0.25$ of the length) occur. They differ from $B$. atlantica in smaller cells with often confluent trigones in lobes and in the absence of underleaves.

In this species, as in some others (Anastrophyllum minutum, Barbilophozia hatcheri, Cephalozia bicuspidata, etc.), the plants affected by small nematodae ( $15-25$ $\mathrm{mkm}$ in diam. and $300-1000 \mathrm{mkm}$ long) were found. Their apical leaves become coarser, develop unusual for the species purplish, blackish fuscous, or blackish purple pigmentation and form the characteristic "head" covering the nematodae.

Barbilophozia atlantica (Kaal.) K. Muell.

NT: Tomboitcsyo 1; ST: Khutyyaha I.

In dwarf shrub-sedge tundra and Sphagnum willow stand in flood plain, asscciated with Lophozia ventricosa, $L$ incisa and Ptilidium ciliare.

The plants from Tomboitosyo are mostly quite typical. They are characterized by wide leaves (width/length ratio of 3-lobed leaves $1.42-1.67: 1$ ) divided in $0.25-0.45$ their length in (2) 3 wide obtuse to apiculate (with 1 - celied apiculus) lobes; large cells, marginal - $21-26 \mathrm{mkm}$, median - 25 $32(35) \times(21) 24-28 \mathrm{mkm}$, with weakly convex, never confluent trigones; underleaves near shoot apexes; sporadic occurrence of stalked slime papillae near the base of ventral leaf margin. Together with plants characterized above, several shoots with predominantly bilobed leaves were mentioned. The distinctive feature of the plants from Khutyyaha is an absence of amphigastria. In the other respects they are quite typical. All Yamal plants of Barbilophozia atlantica have gamma-like, somewhat reflexed sinuses, giving them a peculiar appearance.

\section{Subgen. BARBILOPHOZJA}

\section{Barbilophozia hatcheri (Evans) Loeske}

AT: Tambey III, Kharasavey III; NT: Matyuiyaha I, Tiutey I, Neromayaha I, Manty to If, Marre Sale 6, Sebayaha I, Khakhayayaha II, Lyakkotosyo II; ST: Khutyyaha II, Khevesyo I.

In diverse herb cormmunities on sandy and loamy sand soils situated mostly on steep, occasionally nival, slopes; in diverse lichen tundras on sandy soil. Almost always with gemmae.

Together with quite typical plants the plants of mod. parvifoita-colorata-eciliatagemmipara occur often. They have small size, to 2 - $4 \mathrm{~mm}$ long and $0.5 \mathrm{~mm}$ wide, deep brown pigmentation, (2) 3 - lobed or predominantly bilobed leaves with obtuse or briefly apiculate lobes and mostly without cilia near ventral leaf base (only on individual leaves solitary, short cilia composed of 2 - 4 cells can be found). The plants of this modification may be confused with small forms of Barbilophozia barbata. They differ from it, however, in considerably smaller size, sporadic occurrence of cilia near ventral leaf base, underleaf structure, and constant presence of gemmae.

Occasionally Barbilophozia hatcheri is associated with $B$. lycopodioides. In Lyakkotosyo transitional forms of the both species from mod. parvifolia-colorata to mod. megafoliaviridis were found in one specimen. In this case $B$. hatcheri differed from $B$. lycopodioides in constant presence of gemmae (even small plants of mod. parvifolia-colorata of $B$. lycopodioides with 2 - 3 -lobed leaves do not develop gemmae), shorter cilia and lobe apiculi composed of shorter cells and almost straight, not distinctly convex lobe sides. These observations confirm the taxonomic status of $B$. hatcheri as a species, not a variety of B. lycopodioides (cf. Schljakov 1980).

Barbilophozia rubescens (Schust. \& Damsh.) Karttunen \& Soederstroem ( $B$. hatcheri var. grandiretis Lammes)

AT: Tambey I, Kharasavey II; NT: Bovanenkovo $l$, Marre Sale I, Khakhayayaha II.

In moss tundras and herb communities on nival slopes, associated with Ptilidium ciliare, Barbilophozia hatcheri, B. lycopodioides and Tritomaria quinquedentata.

Once 
(Kharasavey) with few gemmae, 25 $36 \times 23-34 \mathrm{mkm}$, deep purple or reddish brown, mostly 2 - celled, 3 - 4 - angular to polygonal, with feebly projecting angles (cf. Schuster 1988).

Barbilophozia rubescens, for comparison with $B$. hatcheri and $B$. lycopodioides is characterized by robust size contrasting with usually small underleaves occurring only near shoot apicies; fewer cilia (1 - 3) sporadically developing near ventral leaf base and composed of not strongly elongated rectangular cells $(30-60 \times 14-20 \mathrm{mkm}$, width/length ratio $1: 1.5-3.0)$, larger cells with numerous oil-bodies (5)8 - 16(18) per cell, etc. (see also Schuster 1988).

\section{Barbilophozia lycopodioides (Wallr.) Loeske}

AT: Kharasavey I; NT: Matyuiyaha I, Marre Sale 3, Saletayaha 3, Khakhayayaha III, Lyakkotosyo I; ST: Khutyyaha 1, Yuribey 2.

In herb communities at the foot of steep slopes and wet herb-grass tundra, associated with Barbilophozia hatcheri, B. rubescens, Tritomaria quinquedentata, Ptilidium ciliare, and Lophozia heterocolpos. Almost always without gemmae, occasionally with perianths.

Barbilophozia barbata (Schmid. ex Schreb.) Loeske var. barbata

NT: Matyuiyaha I, Bovanenkovo 1, Neromayaha I, Marre Sale l, Lyakkotosyo I.

In moss willow stands and lichen-moss tundras.

Barbilophozia barbata var. amphigastriata K. Muell.

NT: Neromayaha I, Marre Sale 1.

In herb-willow-moss tundra and flood plain willow stand, with $B$. barbata var. barbata and Ptilidium ciliare.

The varietal status of var. amphigastriata is doubtful. Possibly it is only a modification of the polymorphous Barbilophozia barbata.

Lophozia (Dum.) Dum.

Subgen. PROTOLOPHOzia Schust.

Lophozia debiliformis Schust. \& Damsh.

NT: Khakhayayaha I, Sebayaha 1; ST: Er'yaha I.

In willow stands on slope, late snow area and bank of brook, usually on fine-grained soil with Tritomaria quinquedentata f. gra- cilis, Lophozia excisa, $L$ ventricosa s.l., Scapania curta var. grandiretis, Barbilophozia hyperborea, B. lycopodioides and Pleurocladula albescens, or in pure mats. In Khakhayayaha with gemmae.

\section{Subgen. LEIOCOLEA K. Muell.}

The species of Leiocolea are basiphilous and, consequently, very rare in Yamal occuring only in sites with comparatively rich soils. The only acid-tolerant species of the subgenus, Lophozia heterocolpos, is not uncommon on the peninsula.

\section{Lophozia rutheana (Limpr.) M.A. Howe}

NT: Bovanenkovo $l$.

In cotton grass-sedge-hypnum moss bog, among Calliergon sarmentosum, Scapania irrigua var. rufescens, Barbilophozia quadriloba f. glareosa, Tritomaria quinquedentata, etc.

Lophozia gillmanii (Aust.) Schust.

NT: Bovanenkovo 2; ST: Khutyyaha I.

In Equisetum and Sphagnum willow stands with Plagiochila asplenioides subsp. porelloides, Aneura pinguis, Lophozia heterocolpos var. arctica, Chiloscyphus fragilis, Mesoptychia, Blepharostoma, etc.

\section{Lophozia collaris (Nees) Dum.}

AT: Belyy I (Zhukova \& Rebristaya 1987); ST: Laptayaha 1 .

In spotty herb-willow Racomitrium - Gymnomitrion tundra and in tundra shortgrass meadow; individual plants and small tufts in association with Nardia geoscyphus, Cephalozia pleniceps, and Lophozia sp.

Lophozia heterocolpos (Thed. ex Hartm.) M.A. Howe var. heterocolpos

AT: Belyy (Arnell 1918), Khabeiyaha I, Kharasavey I; NT: Matyuiyaha I, Tiutey 2, Bovanenkovo 1 , Tomboitosyo I, Neromayaha II, Saletayaha 1, Yuribeitoyaha IV, Lyakkotosyo I; ST: Khevesyo I; Laptayaha II.

In diverse wet tundras, occasionally in late snow areas, once in fire place. Often with gemmae, once with perianths.

Lophozia heterocolpos var. arctica (S. Arn.) Schust. \& Damsh.

AT: Kharasavey I; NT: Neromayaha III; Yuribeitoyaha II, Khakhayayaha I, Lyakkotosyo I; ST: Khutyyaha I, Khevesyo I.

In Equisetum-herb, herb-dwarf shrub-moss and willow-sedge-moss tundras, at the foot of 
steep slopes, associated with Blepharostoma trichophyllum var. brevirete, Lophozia heterocolpos var. heterocolpos, L. excisa, Ptilidium ciliare, Tritomaria quinquedentata, T. scitula, Barbilophozia spp., Odontoschisma macounii, Scapania cuspiduligera, Preissia, etc. Sporadically with gemmae and perianths. The gemmae often develop on rather stout flagellae with reduced leaves, similar to those of var. heterocolpos. The perianth in var. arctica lacks a beak and is more or less plicate, at least with one plica in dorsal part when immature and smooth when mature (only one mature perianth has been seen). The mouth of the perianth varies from faintly crenulate to sparsely dentate and the teeth are composed of $1-3$ subisodiametric cells.

The degree of manifestation of the perianth beak in the type variety of the species varies greatly - from undetectable or rudimentary to rather long and narrow. A plicate perianth surface occurs in var. heterocolpos also (cf. Schuster 1974, Fig. 163: 8, 9). Consequently, the presence of beak and plicae considered as significant generic or infrageneric criteria (cf. Mueller 1951-1958; Inoue 1957, 1961; Schuster 1974; Schljakov 1980, etc.) has only a little infraspecific value.

This comparatively poorly known taxon is rather common, not only in Yamal but in the Asian Arctic as a whole. It differs from the type variety of the species by larger cells (marginal - $20-30(34) \times 23-35(40) \mathrm{mkm}$, median - $23-35 \times 24-42 \mathrm{mkm}$ ) and gemmae $(18-23 \times 24-38 \mathrm{mkm})$, a mostly smooth or faintly papillose cuticle, more numerous oil-bodies ((3) 4 - 11(16) per cell), Barbilophozia barbata-like leaves that are 2(3) - lobed, exceptionally 4 -lobed, often developing purplish pigmentation, etc.

Lophozia heterocolpos var. harpanthoides (Bryhn \& Kaal.) Schust.

\section{AT: Belyy II.}

In herb-willow-moss tundras with Blepharostoma trichophyllum var. brevirete, Tritomaria quinquedentata, Odontoschisma macounii, Scapania zemljae, Jungermannia polaris, Cephaloziella arctica, etc.

The investigated plants are mod. mesoderma-colorata of the variety with straight- sided, rarely weakly convex, never confluent trigones. Small-leaved phenotypes often develop purplish violet pigmentation in distal parts of leaves. One shoot with a ventral-intercalary branch originating from the underleaf axil was found also. Otherwise the material is quite typical. It has narrow and shallow sinuses with convex sides, usually rotund lobes, often bilobed amphigastria, and comparatively small, subisodiametric basal and median leaf cells (median ca. 20 - $31 \times 17$ $24 \mathrm{mkm}$ ).

Lophozia badensis (Gott. ex Rabenh.) Schiffn. ex Dalla Torre \& Sarnth.

AT: Kharasavey I; NT: Yuribeitoyaha I.

In hillock tundra on brooklet bank and in dwarf shrub spotty tundra on bare soil, associated with Jungermannia polaris, Arnellia fennica, Scapania gymnostomophila f. incurva, Tritomaria scitula, Lophozia heterocolpos, and Barbilophozia quadriloba f. glareosa.

In Kharasavey plants of mod. parvifoliamesoderma-colorata were found. The smallest plants of this modification have subtransversely oriented, more or less concave and fuscous leaves and resemble small species of Marsupella. In the sterile state they differ from Marsupella by stem anatomy and comparatively large cells.

\section{Subgen. SCHISTOCHILOPSIS Kitag.}

Lophozia grandiretis (Lindb. ex Kaal.) Schiffn.

ST: Khevesyo III, Laptayaha II, Er'yaha I.

On spots in spotty moss and lichen-moss tundras, bare loamy soil near temporary water course and peat outcrop, associated with Cephalozia pleniceps, Blepharostoma trichophyllum var. brevirete, Anthelia juratzkana, Nardia geoscyphus, Tritomaria heterophylla, T. quinquedentata, Aneura pinguis, Odontoschisma macounii, etc. Gemmae usually develop in small quantity. Male plants were found once. Antheridia vary from green to yellow and purplish. The stalks are $\mathbf{2}-$ or, at least partly, 3 - seriate.

The color varies from green to deep purple. Plasmolysis, resembling that of Lophozia opacifolia, occurs exceptionally in plants of mod. viridis. Such plants differ from $L$ 
opacifolia in their dirty green, not bluish green coloration, as well as the size of cells and gemmae.

\section{Lopozia incisa (Schrad,) Dum. s.sir.}

AT: Tambey $\mathrm{l}$, Khabelyaha $\mathrm{H}_{0}$ Kharasavey $\mathrm{II}$; NT: Matyuiyaha I, Bovanenkovo 1, Tomboitosyo 1, Neromayaha III, Manty Io Saletayaha 1 , Yuribeitoyahe I, Khakhayayaha II, Lyakkotosyo I; ST: Khutyyaha II, Khevesyo II, Laptayaha I, Er'yana I, Khadytayaha $I$.

In diverse wet moss lundras, bogs, peat outcrops, often arnong Sphagnum. Usually with gemmae. Male plants were found only once.

Among Sphagum the plants of mod. laxifolia-integrifolia, resembling Lophozia laxa (Lindb.) Grolle, sporadically occur. They differ from this species by opaque bluish green coloration, absence of purplish pigment, character of gemmae, etc. Moreover $L$. laxa is an amphi-cceanic species apparentiy unknown from continental regions of Eurasia (Konstantinova \& al., 1992).

When sterile differentiation of $L$ incisa from $L$ opacifolio is problematic on account of considerable overlapping of their variability (cf. Schuster 1969, 1988, etc.). Usually plants of $L$ incisa are smaller, with thinner stems, and narrower, seeper divided leaves, 2-3-stratose only near the base. Moreover, th incisa is associated with acidophilous speries, while Lo opacifolia occurs on enriched soils.

Lophozia incisa var, inemis K. Muell.

AT: Tirvyyaha $t$.

In wet willow-moss iundra among Sphagnum sp., Barbilophozia biristeadii, Ptilidium ciliare, Blepharostoma trichophyllum var. brevirete. In my opinion, the most characteristic feature of this rare varicisy, which is unknowr for the other taxa of the subgenus, is the prominen bulging trigones.

\section{Lophoais opacifolia Culm. ex Meyl.}

AT: Belvy Ii, Xhaireiyahn III, Tambey III, Kharasavey II; NT: Matyuigaha I, Bovanenkovo 1 , Tomboitosyo I, Neromaysha II, Manty io I, Yuribeitoyaha II, Khikhayayah II; ST: Khutyyahe I, Khevesyo III, Yuriboy 2 , Es'yaha I.

On spots of bare soils in diverse tundras, late snow areas at the foot of slopes and peat outcrops, and on brooklet banks. Usually with gemmae. Male plants and plants with perianths and mature capsules rare.

Some phenotypes of Lophozia opacifolia resemble L. hyperarctica Schust. They have very thick, fleshy and flattened, elliptical in cross section, blackish brown pigmented with age stems; predominantly bilobed, very wide, almost transversely inserted dorsally leaves, with shallow crescentic sinus and entire or faintly denticulate (on gemmiparous shoots) margins; and large gemmae, 20 $34(40) \times 20-31 \mathrm{mkm}$. They differ from $L$. hyperarctica in opaque, whitish green coloration; characteristically plasmolysed cell contents; absence of black pigmentation of cell walls in old parts of ventral sector of stem (brownish black coloration of old part of stem of $L$ opacifolia connected with destruction of the cell walls, not with black pigmentation); presence of diffuse mycorrhiza in ventral part of stem.

\section{Subgen. ISOFACHES (Buch) Schust.}

For a description of Lophozia alboviridis and $L$ decolorans in Yamal and differentiation of the species of the subgenus see Potemkin (1990c). I would like to note here only the most important distinctive criteria of the species of the subgenus in the key given below and to stress that sex distribution is not constant in arctic populations of Isopaches species: $L$ alboviridis in Yamal, as well as in Greenland (Schuster \& Damsholt 1974) is mostly dioicous but sporadically paroicous; $L$ decolorans in Yamal is paroicous, but in the other localities dioicous; in L. bicrenata male plants occur sporadically, while as a rule this species is paroicous.

\section{KEY TO SPECIES OF ISOPACHES}

1. Marginal leaf cells considerably smaller than median, $11-18(20) \mathrm{mkm}$; leaf lobes more or less unequal, ventral lobe longer and wider than dorsal, ending in sharp tips formed by (1) $2-3(4)$ superimposed celis with distinctly elongated apical cell; gemmae with strongly projected and very thick angles, mostly regulary stellate, $19-25(26) \times 16-$ 24 mkm..................................L. alboviridis

1. Marginal cells not distinctly different from median, larger than $20 \mathrm{mkm}$; leaf lobes usually almost equal, ending in obtuse to 
sharp apiculi formed by 1(2) superimposed subisodiametric cells; gemmae variable, from mostly irregularly polygonal to rectangular and triangular, with feebly to rather strongly projecting and thickened angles, as an exception - oval, 17 - 25 × 23 - 31 mkm (Lophozia bicrenata) or $17-30(34) \times 23-45(56)$ mkm ( $L$ decolorans)

2. Leaves usually densely imbricate, wide (width/length ratio usually considerably more than 1:1.2), trapezium-like, with mostly shallow wide crescentic sinus, $0.05-0.15$ of the leaf length (sterile plants resemble Prasanthus suecicus); male bracts with antical tooth; perianth mouth shortly ciliate, cilia 1 2(3) - celled; often with stolons. L. decolorans

2. Leaves not densely imbricate, their width not obviously exceeding their length (width/legth ratio ca. 1:0.9-1.2); sinus deeper, $0.2-0.3$ of the leaf length, mostly U-shaped, occasionally crescentic (plants essentially different from Prasanthus suecicus); male bracts usually without antical tooth; perianth mouth spinose-ciliate, cilia 2-4celled; stolons absent..................L. bicrenata

Working with this key, the following correlation should be taken into account: gemmae are more angulate and thick-angled but cilia of perianth mouth and apiculi of leaf lobes are shorter and leaves are denser in plants of exposed sites and just the opposite for plants of shade sites.

Lophozia bicrenata (Schmid. ex Hoffm.) Dum.

ST: Khutyyaha I.

On thinly turfed sandy soil in dwarf shrubherb moss tundra on steep slope, in association with $L$ alboviridis, Gymnomitrion corallioides, Lophozia excisa and Cephaloziella arctica. With perianths and gemmae.

\section{Lophozia alboviridis Schust.}

AT: Kharasavey I; NT: Matyuiyaha I, Neromayaha III, Manty to I, Saletayaha 2, Khakhayayaha II, Lyakkotosyo I; ST: Khutyyaha III, Khevesyo I, Laptayaha I, Er'yaha I.

On weakly turfed sandy and loamy sand soils, sometimes with the other species of the subgenus. Always with gemmae; male plants and plants with perianths occur rarely; seen once with mature capsules. Potemkin (1990c, fig. 1) provides illustrations of this species by material from Yamal.

\section{Lophozia decolorans (Limpr.) Steph.}

AT: Tambey II; NT: Lyakkotoeyo I; ST: Khutyyaha I.

On steep herb sandy slopes, associated with Barbilophozia hatcheri, Gymnomitrion corallioides, Lophozia excisa, L alboviridis, Scapania praetervisa, Anastrophyllum minutum, etc. With gemmae and perianths. Potemkin (1990c, fig. 2) provides illustrations of this species by material from Yamal.

\section{Subgen. LOPHOZIA}

Lophozia heteromorpha Schust. \& Damsh. (Fig. 3)

NT: Bovanenkovo 1, Neromayaha I; ST: Khevesyo I.

In spotty dwarf shrub formation with Betula nana, among Dicranum elongatum with Lophozia excisa var. infuscata, $L$ major, $L$ heterocolpos, Blepharostoma trichophyllum var. trichophyllum; in lichen-moss-dwarf shrub tundra, among Sphagnum with Barbilophozia kunzeana; at the foot of steep herb slope near margin of sedge bog with Pellia neesiana, Chiloscyphus fragilis, Scapania irrigua, Cephalozia pleniceps, and Jungermannia hyalina. With gemmae.

Lophozia heteromorpha is a polymorphous species with unclear limits of variability. The most important features, differentiating it from the other taxa of Lophozia, are: polymorphous leaf form; violetish pigmentation of mature gemmae; violet pigmentation of young leaf margins in distal parts, replaced by fuscous pigment with age; frequent presence of amphigastria; and weak dorsiventral differentiation of stem tissue. All these characters are not constant, however, and only a complex analysis of them all permits sure identification of the species (see also Potemkin 1990a).

Lophozia jurensis Meyl. ex K. Muell. ( $L$ latifolia Schust.; $L$ sudetica auct. non (Nees ex Hueb.) Grolle p.p. - Potemkin 1989; L pellucida var. minor auct. non Schust. Potemkin 1988, 1989)

AT: Belyy II, Tambey II, Kharasavey II; NT: Matyuiyaha II, Tiutey 2, Bovanenkovo 1, Neromayaha III, Yuribeitoyahe I, Khakhayayaha I, Lyakkotosyo II; ST: Khutyyaha I, Khevesyo II, Laptayaha II, Kharangyneto 4, Er'yaha I, Khadytayaha 3. 
A. D. POTEMKIN

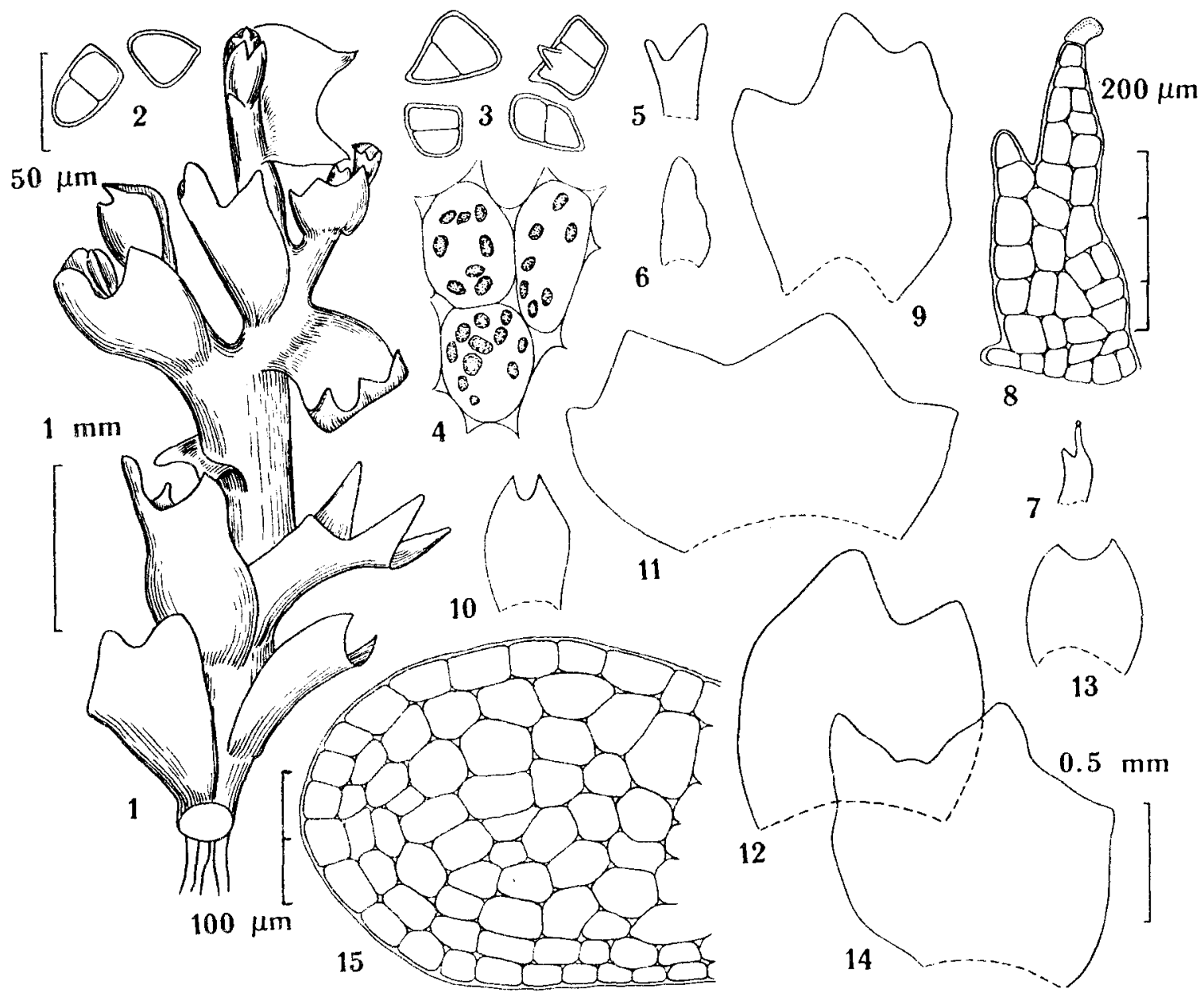

Fig. 3. Lophozia heteromorpha. 1 - Sterile shoot; 2, 3-Gemmae; 4 - Median cells with oil-bodies; 5-7 - Underleaves; 8 - Magnified underleaf from Fig. 7; 9-14 - Leaves; 15 - Cross section of stem. Scale bars: $1 \mathrm{~mm}$ - for $1 ; 0.5 \mathrm{~mm}$ - for 5 - 7, 9 - 14; $200 \mathrm{mkm}$ - for 8; $100 \mathrm{mkm}$ - for 15; $50 \mathrm{mkm}$ - for 2 - 4. All from Khevesyo (After Potemkin 1990a).

In diverse moss tundras. Often with perianths, rarely with gemmae and mature capsules.

Yamal plants are mostly paroicous. Individual monoicous shoots were found only in Yuribeitoyaha, Lyakkotosyo and Laptayaha. The species varies from mod. laxifolia-viridis to mod. densifolia-colorata. Secondary pigmentation is usually purplish red. Plants of mod. laxifolia-viridis often represent phenocopies of Lophozia pellucida var. minor (cf. Schuster 1969, Fig. 220:11). They differ from this species in: 1) almost constant absence of gemmae (if gemmae present, they are reddish brown or reddish, with faintly projecting angles (vs strongly angulate, colourless to yellow and yellowish brown gemmae of $L$ pellucida); 2) male bracts with antical teeth; 3) ecological behaviour - $L$ jurensis associated with acidophilous species while $L$ pellucida with basiphilous ones.

Lophozia excisa (Dicks.) Dum. (? L. uncinata Schljak. syn. nov.).

In Yamal three varieties of $L_{0}$ excisa, representing apparently more or less distinct entities of this genetically highly complicated species are distinguished. My approaches to their differentiation are given in the key.

Key TO YAMAL VARIETIES OF LOPHOZIA EXCISA

1. Perianth mouth crenulate or dentate, composed of more or less regulary projecting, oriented perpendicularly to margin, elon- 
gated, finger-like cells. Mature gemmae reddish brown to dull purplish. .2

1. Perianth mouth with smooth margin, composed of mostly tangentially oriented cells, and scattered 1-2(3)-celled firm teeth formed by mostly subisodiametric cells. Mature gemmae colourless to violetish .L excisa cf.var. succulenta

2. Perianth mouth crenulate; marginal cells, in lobes, $17-30 \mathrm{mkm}$ (tangentially measured) ............................ excisa var. excisa

2. Perianth mouth dentate, with free teeth $0.5-2(3-4)$ cells long; marginal cells, in lobes, (25) $30-40(42) \mathrm{mkm}$ (tangentially measured) .................... excisa.var. infuscata

Lophozia excisa var. excisa ( $L$. sudetica auct. non (Nees ex Hueb.) Grolle p.p. Potemkin 1989)

AT: Belyy II, Khabeyyaha III, Tambey III, Kharasavey II; NT: Matyiyaha I, Tiutey 1 , Bovanenkovo! Tomboitosyo II, Neromayaha IV, Manty to I, Marre Sale 1, Saletayaha 7. Yuribeitoyaha II, Khakhayayaha III, Lyakkotosyo III; ST: Khutyyaha III, Khevesyo III, Yuribey 1, Laptayaha II, Kharangyneto 1, Er'yaha II.

In diverse moss and spotty tundras, on herb slopes, late snow areas, peat outcrops, moss bogs, banks of water courses and lakes. Often with perianths and gemmae, sporadically with mature capsules.

An euritopic, extremely malleable taxon, varying from mod. laxifolia-viridis-egemmipara, occurring in wet sites among mosses, to mod. parvifolia-densifolia-colorata-gemmipara, which is characteristic for habitats on bare soil. The smallest plants of the last modification are only $0.8-0.9 \mathrm{~mm}$ long and $0.2-0.35 \mathrm{~mm}$ wide. They usually have a thick, fleshy stem and comparatively small leaves as well as comparatively small cells, (17) $22-30 \times(17) 20-25(28) \quad \mathrm{mkm}$, with small trigones. Their gemmae are 2 - celled, $21-31(36) \times 17-25(28) \mathrm{mkm}$, and from brown and brownish red to deep purple.

Yamal plants of Lophozia excisa var, excisa develop brown pigmentation more often than red or purplish. This may lead to confusing $L$ excisa and Lo major. Such forms of $L$. excise, however, have leaves not so strongly narrowed in upper part, as in $L_{s}$ major, with the maximal width between the middle and lower thirds or in the middle, not near the base, and almost triangular, not horn-like lobes (if the maximal width of leaves of $L$ major is in the middle, their ventral margin is very convex but the dorsal is almost straight, i.e. the leaves of this species are usually considerably more asymmetric than in $L_{\text {e excisal }}$.

Small gemmiparous plants of Lophozia excisa are confused also with $L$ sudetica. They differ from this species in their wide ventral merophytes, unmodified gemmiparous leaves, also often in larger cells as well as size, shape and coloration of gemmae, etc. Moreover $L$ excisa differs from all other regional species of the subgenus, excepting $L$. jurensis, in paroecia and, as a consequence, in often developing perianths.

Lophozia excisa var. infuscata Schust \& Damsh.

AT: Khabeiyaha I; NT: Neromayaha II, Lyakkotosyo I; Sr: Er'yaha I.

In willow stands on humused soil with Barbilophozia binsteadii, $B$. kunzeana, $B$. quadriloba, Anastrophyllum minutum, Cephalozia pleniceps, Tritomaria quinquedentata, Blepharostoma, etc.; in wet moss tundra among Aulacomnium palustre, with Tritomaria quinquedentata and Lophozia major. With gemmae, perianths and mature capsules.

The differentiation of this variety, recently described by Schuster and Damsholt (1974) and known before this report only from Greenland, is sometimes rather problematic. Its distinctive criteria, mentioned by the authors - larger cells (marginal in lobes - $(26$ 29) 30 - 38(40) mkm, median - $(32-35) 36$ $45(48) \times(36) 40-55(60) \mathrm{mkm})$ and gemmae, (28) $30-37 \times 33-38(48) \mathrm{mkm}$; more numerous oil-bodies, $(12-18) 20-36(40-$ 45) per cell; fuscous secondary pigmentation; dentate perianth mouth with free teeth 0.5 $2(3-4)$ cells long and terminal cells (where free) ca. $56-68(75-80) \times 16.5-22 \mathrm{mkm}-$ are mainly quantitative. Their variability overlaps with that of the type variety. The most reliable of these criteria, for separation of the Yamal plants of the variety, are character of perianth mouth and size of marginal cells of leaf lobes. 
Lophozia excisa cf, var. succulenta Schust. \& Damsh.

AT: Belyy II, Khabelyaha II, Tambey I, Kharasavey I; NT: Neromayaha I; ST: Khutyyaha I, Khevesyo I.

On bare fine-grained soil in late snow areas and diverse spotty tundras; mostly individual shoots among Prasanthus suecicus, Gymnomitrion corallioides, $G$. concinnatum, Nardia geoscyphus, Scapania scandica, Tritomaria quinquedentata f. gracilis, Lophozia ventricosa s.l., Cephalozia bicuspidata, Anthelia juratzkana, Cephaloziella arctica, Anastrophyllum minutum, Jungermannia sphaerocarpa var. nana, etc. Often with perianths, gemmae and mature capsules.

The variety was described from West Greenland by Schuster and Damsholt (1974) on the base of "sparing type material", which was unavailable for critical study. It is obvious that this material can not reflect the phenetic variability of the taxon completely. It gives me the basis to attribute to the cf. var. succulenta the Yamal plants that differ somewhat from the type until an investigation of the type is possible. Because of the tentative identification of these plants, their description and differences from the type are listed.

Plants minute to small, $1-10 \mathrm{~mm}$ long and (0.2)0.5-1.1 $\mathrm{mm}$ wide, resembling small compact soil forms of Lophozia excisa var. excisa. Stem more or less fleshy, thick, conspicuously mycorrhizal throughout much of the medulla. Leaves usually subrotund, broader than long, imbricate, subvertical, often 2(3) - stratose at base; sinus mostly crescentic, occasionally gibbous, ca. 1/5 $2 / 5$ of the leaf length; lobes acute; distal parts, especially margins, of young leaves bright red to deep purple and violet, of mature and old leaves - fuscous (brown pigment replaces red pigment with age), unpigmented parts of leaves and stem in dead material opalescent. Cells of leaves thin-walled, except for small to sporadically rather pronounced trigones; marginal cells in lobes, $17-28$ mkm (measured tangentially), median from $14-17 \times 17-23 \mathrm{mkm}$ to $20-25(28) \times 25-$ 30(35) mkm; oil-bodies small, $3-5(6) \mathrm{mkm}$, 4 - 12(14) per cell, according to Schuster and Damsholt (1.c.) occasionally $18-20$ per cell.
Gemmae green to violetish (only individual "overmatured" gemmae deep violet), 1 - 2 celled, usually thin-walled, almost oval to triangular and polygonal, with weakly projected angles, $20-23 \times 23-34 \mathrm{mkm}$.

Paroicous. Male bracts leaf-like, often with somewhat gibbous base, 1 - 2-androus, with or without distinct antical tooth. Female bracts $2-3$ - fid; lobes acute to apiculate (apiculus $1-3(5)$ cells long) often with strongly reflexed margins; sinuses rather deep, angulate, gibbous. Perianth 2 - 5(10) stratose at base, usually bistratose up to middle or higher, at mouth usually bleached, weakly lobulate, occasionally formed of rather thick-walled collenchymatous cells; the mouth margin smooth, composed of mostly tangentially oriented cells, with scattered 1 $2(3)$ - celled firm teeth formed by mostly subisodiametric, only as an exception by elongated cells. Capsule wall $3-4$ - stratose with epidermal layer usually considerably thicker than any of inner ones (the thicknesses ratio ca. $1.5-2.0: 1)$. Spores 16 18(20) mkm. Elaters 2 - spiral, (7)8 - 9(11) mkm thick.

In their description of this variety Schuster and Damsholt (l.c.) stressed that "the combination of denticulate, firm-celled perianth mouth, the polystratose perianth base, and edentate bases of male bracts isolate these plants from any other variety of $L$ excisa". In my opinion, the most important of these criteria is the character of perianth mouth the combination of scattered teeth and smooth margin, composed of tangentially elongated cells (a firm-celled peranth mouth is not constant for the Yamal plants of var. succulenta and it has been seen in var. infuscata also). The character of the perianth base as well as the leaf base (the authors note unistratose leaf base for the variety) is not a very reliable feature. According to my per-sonal observations a 2-3-stratose perianth base is not a rarity for the typical variety of the species. A bistratose leaf base and edentate male bracts occur exceptionally in var. excisa also. On the other hand, "sparing type material" cannot show the degree of constancy of these characters and the constancy of the absence of gemmae 
stressed in the description.

\section{Lophozia cf. longidens (Lindb.) Macoun}

AT: Khabelyaha II, Tambey I.

In lichen and lichen-moss tundras, individual plants among lichens with Anastrophyllum minutum, Tritomaria quinquedentata, Ptilidium ciliare, Gymnomitrion concinnatum, etc. With gemmae.

Because some species of Lophozia in certain conditions may develop phenocopies of $L$ longidens and collections of the species in Yamal are sparing and unsufficient for its sure identification it listed under the sign "cf.".

Lophozia cf. savicziae Schljak. ( $L$ wenzelii auct. non (Nees) Steph. - Zhukova \& Rebristaya 1986, 1987)

AT III; NT: Matyulyaha II, Bovanenkovo 8, Tomboitosyo II, Neromayaha IV, Mantyto II, Khakhayayaha II, Lyakkotosyo I; ST: Khutyyaha III, Khevesyo V, Laptayaha II, Kharangyneto 2, Khadytayaha 4.

In diverse wet moss, moss-lichen and lichen tundras, late snow areas, on spots in spotty tundras, steep slopes and in bog communities. Often with gemmae; male plants rare.

The most characteristic features of the species are concave, trapezium-like, rather rigid leaves, spread away from the stem from their bases, with a rather shallow, usually lunate sinus and mostly apiculate lobes; often deep purple ventral sector of stem as well as ventral leaf bases; polygonal to stellate gemmae with strongly thickened and projecting angles; usually large cells.

In original description of the species Schljakov (1973) noted two types of oil-bodies small, 2 - $4 \mathrm{mkm}$, homogenous, drop-like, 15 - 30 and more per cell, or, if they are larger, they are less numerous, granulate, with central droplet. Later (Schljakov 1980) he listed granulate oil-bodies without central droplet for the species also, interpreting the polymorphism of oil-bodies as a feature of its antiquity. Oil-bodies with central droplet, ca. (5) 8 - 18(20) to 15 - 30 per cell, $3-7 \mathrm{mkm}$ in diam., were found in most collections of the species studied in a living state (mainly from Bovanenkovo, Neromayaha, Khevesyo). In some specimens of the species from the same localities granulate oil-bodies without central droplet were found. The differentiation of (?) forms of the species with granulate oil-bodies and oil-bodies with central droplet from the other large-celled Lophozia, namely $L$ ventricosa var. grandiretis (Buch \& S. Arn.) Schust. \& Damsh., L. ventricosa var. rigida Schust. as well as $L$ wenzelii var. lapponica Buch \& S. Arn. sensu Schust. remains unclear. As a consequence, the conception of the species, particulary in respect of oil-body polymorphism, remains unclear also.

Lophozia ventricosa (Dicks.) Dum. s.l. (incl. L groenlandica (Nees) Macoun sensu Schljak. 1975, non sensu Schust. 1969, excl. syn. L heteromorpha Schust. \& Damsh., )

AT: Belyy I, Khabeiyaha III, Tambey III, Kharasavey II; NT: Matyuiyaha V, Tiutey $l$, Venuieuo $l$, Bovanenkovo 4, Tomboitosyo III, Neromayaha III, Manty to II, Marre Sale I, Saletayaha 1, Yuribeitoyaha II, Khakhayayaha V, Lyakkotosyo III; ST: Khutyyaha V, Khevesyo V, Laptayaha III, Kharangyneto 4, Er'yaha III, Khadytayaha 5 .

In diverse moss and lichen tundras, herb communities, late snow areas, moss bogs. Usually with gemmae; perianth bearing and male plants rare.

Lophozia ventricosa var. longiflora (Nees) Macoun ( $L$. longiflora (Nees) Schiffn. s.l., incl. $L$ porphyroleuca auct. non Schiffn.; $L$. ventricosa auct. non (Dicks.) Dum. p.p. Zhukova \& Rebristaya 1986)

AT: Belyy I, Khabelyaha IV, Tambey III, Kharasavey II; NT: Matyuiyaha III, Tiutey 2, Venuleuo 1, Bovanenkovo $I$, Neromayaha III, Mantyto $\mathrm{V}$, Marre Sale 7 , Saletayaha 7, Yuribeitoyaha IV, Khakhayayaha II, Lyakkotosyo IV; ST: Khutyyaha V, Khevesyo V, Yuribey 2, Laptayaha V, Kharangyneto 5 , Er'yaha III.

In diverse moss and lichen tundras, moss bogs, occasionally on spots in spotty tundras. Perianth bearing and male plants rather freq-uent; occasionally with gemmae and mature capsules.

\section{Lophozia wenzelii (Nees) Steph.}

AT: Kharasavey I; NT: Matyuiyaha I, Bovanenkovo l, Neromayaha II, Sebayaha I, Khakhayayaha I; ST: Khutyyaha II, Khevesyo I, Laptayaha II, Er'yaha II.

In wet dwarf shrub-moss tundras, once in herb-moss nival tundra. Perianth bearing, male and gemmiparous plants occur sporadically. 
Lophozia sudetica (Nees ex Hueb.) Grolle ( $L$. rufescens auct. non Schljak. - Potemkin 1989)

AT: Tambey II, Kharasavey I; ST: Khutyyaha I, Laptayaha $\mathbf{I .}$

In diverse lichen tundras and spotty Gymnomitrion tundra, on steep slope; individual shoots on fine-grained soil. With gemmae.

Lophozia sudetica is a rare species in Yamal. It is represented by small forms like "Lophozia alpestris var. gelida (Tayl.) K.Muell." A part of the earlier reports of the species from Yamal (Arnell 1918 (?); Zhukova \& Rebristaya 1986, 1987; Potemkin 1989) must be attributed to mod. parvifoliacolorata-parviretis-gemmipara of $L$ excisa, $L$. major and $L$ jurensis, which may develop similar small cells and pigmentation. $L$ sudetica differs from them, however, in considerably more symmetrical leaves, which usually become dentate from gemmae production; narrow ventral merophyte and usually purplish pigmented ventral part of the stem and ventral leaf base.

My attempts to use the leaf cell rows criterion (Schljakov 1980) for separation of this species and Lophozia rufescens Schljak. were resultless. Other criteria for differentiation of small forms of the both species with pigmented gemmae are absent. In my opinion the cell row directions in specimens of $L$ sudetica determined by Schljakov (LE) vary principally from "in lobes" to "to sinus". I am sceptical about this criterion for differentiation of Lophozia species.

Lophozia major (C. Jens.) Schljak. ( $L$ polaris (Schust.) Schusi. \& Damsh.; $L$ alpestris auct. non (Schleich.) Evans. - Zhukova \& Rebristaya 1987)

AT: Belyy II, Khabeiyaha II, Tambey III, Tirvyyaha 1 , Kharasavey II; NT: Matyuiyaha II. Tiutey 2, Venuieuo 1 , Bovanenkovo 8, Tomboitosyo I, Neromayaha IV, Marre Sale I, Yuribeitoyaha $\forall$, Khakhayayaha II, Lyakkotosyo I; ST: Khutyyaha I, Khevesyo III, Laptayaha II, Er'yaha II, Khadytayaha $l$.

In herb-willow-moss, moss-lichen and diverse swampy tundras, herb willow stands, on brook and lake banks. While L. major prefers comparatively rich soils, it is often associated with acidophilous species. Always with gemmae; male and female plants very rare.

In Yamal the species is very malleable in its sinus, which varies from usually crescentic to angulate with concave or convex sides; lobe form, which is often horn-like but sometimes - obtuse- or acute-angled; position of maximal width of the leaf (mostly in the lower third, occasionally in the middle); leaf symmetry (usually the leaves are asymmetric - with strongly convex ventral and stright dorsal margin, but some, mainly small forms of the species have more or less symmetric leaves); cell size, which ranges for median cells from $17-20 \times 23-25 \mathrm{mkm}$ to 28 $35 \times 30-42 \mathrm{mkm}$, etc. There is a certain overlapping of the variability ranges of Lophozia major with $L$ excisa, $L$ sudetica and $L$ rubrigemma (for differentiation see characteristics of these species).

Lophozia cf. rubrigemma Schust.(Fig.4:1-4)

AT: Tambey I; NT: Neromayaha I, Marre Sale 1.

In Cassiope tundra on bare soil with Anthelia juratzkana, Anastrophyllum minutum and Blepharostoma; in willow stand on bare soil among crustose lichens, individual stem with Lophozia major and Scapania hyperborea mod. parvifolia-gemmipara; in willow-moss tundra among with Tritomaria quinquedentata, Ptilidium ciliare, Scapania scandica. With gemmae. The scant Yamal material of the species and rather poor our knowledge of it on the whole as well as the overlapping of variability ranges with Lophozia major cause serious difficulties with identification of $L$ rubrigemma and some problems remain unsoluble.

The plants from Tambey share with typical L. rubrigemma leaf form and leaf position on the stem but differ in comparatively small cells and gemmae (Potemkin 1990a). The plants from Neromayaha are very similar to the type (RMS 45961c), which was investigated for comparison. They have the same leaf form, large cells (marginal 23 $38 \times 20-34$ mkm, median 28 . $37(45) \times 23-31 \mathrm{mkm})$ and gemmae, $23-$ $31 \times 17-28 \mathrm{mkm}$ to $34-41 \times 2028 \mathrm{mkm}$, but material is very sparing. The last specimen, from Marre Sale, is also problematic. The plants are large-celled with pellucid leaves, resembling $L_{0}$ excisa more rather than L. rubrigemina Cells, hovevar, oftar develoo 


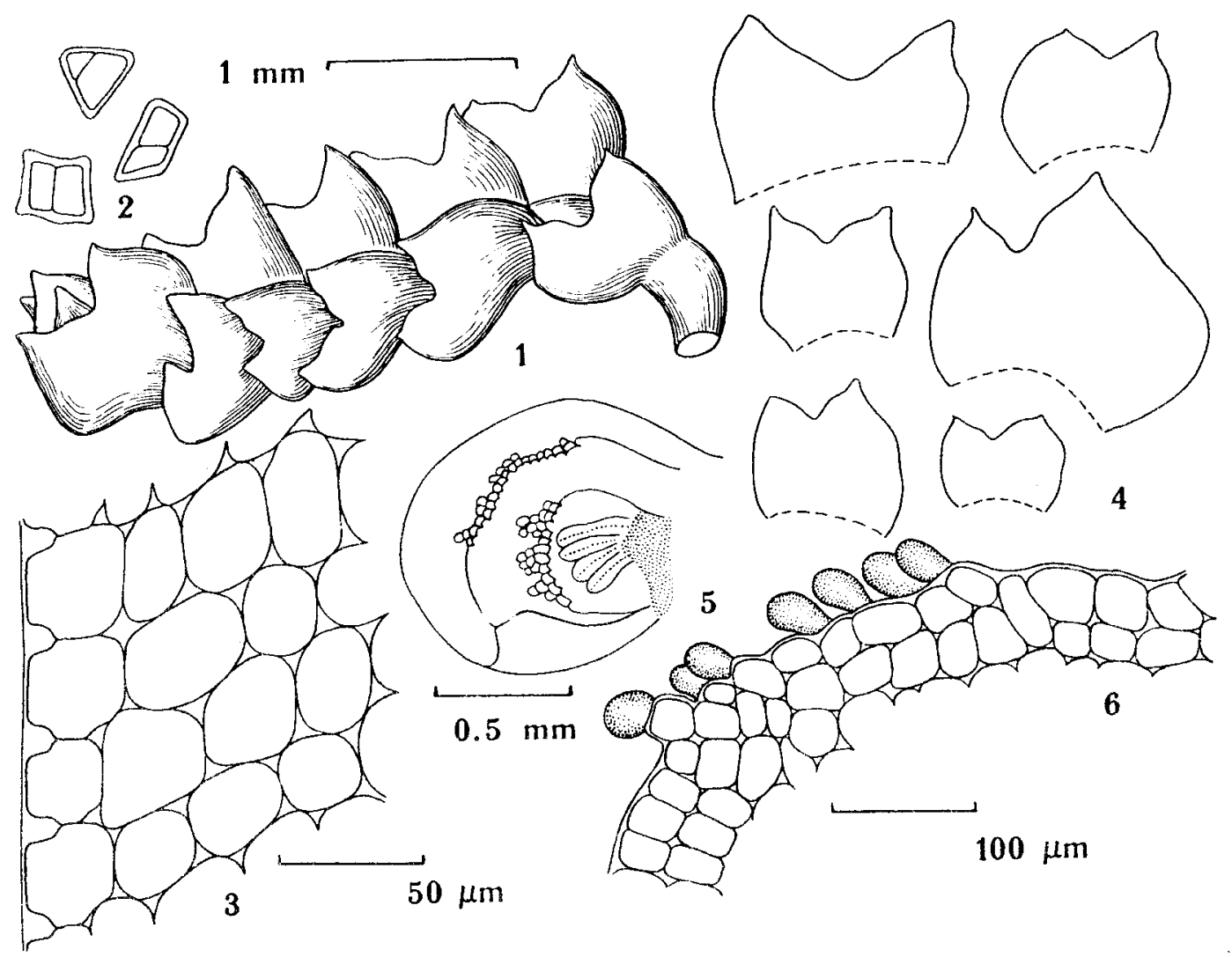

Fig. 4. Lophozia cf. rubrigemma $(1-4)$ and Cryptocolea imbricata $(5,6)$. 1 - Shoot, lateral aspect; 2 - Gemmae; 3 Cells of leaf margin; 4 - Leaves; 5 - Longisection through gynoecium; 6 - Margin of inner bract with slime papillae. Scale bars: $1 \mathrm{~mm}$ - for 1,$4 ; 0.5 \mathrm{~mm}$ - for $5 ; 100 \mathrm{mkm}$ - for $6 ; 50 \mathrm{mkm}$ - for $2,3.1$ - 4 - from Tambey; 5 - 6 - from Khevesyo (After Potemkin 1990a).

somewhat bulging trigones as in $L$. rubrigemma, which do not occur in Lo excisa.

Lophozia pellucida Schust. var. minor Schust.

NT: Neromayaha II, Khakhayayaha I; ST: Khutyyaha l.

It is a true basiphilous species of "difficult sites", growing usually on nival clay and loamy slopes on bare soil with Nardia geoscyphus, Barbilophozia quadriloba, Cephalozia pleniceps, Tritomaria quinquedentata, Lophozia excisa, L. major, L heterocolpos var, arctica, Jungermannia polaris, $J$. obovata s.1., etc.

Lophozia pellucida var. minor is represented in Yamal mosily by very small forms imod angusifolia pat vifclia-fusca nel viridis?, which are often only $0.3-0.4 \mathrm{~mm}$ wide and $1-3 \mathrm{~mm}$ long. They have subisodiametric to rectangular, not strongly elongated cortical cells, $14-25 \times 25-70 \mathrm{mkm}$, and small leaf cells, often $17-23 \mathrm{mkm}$ only. Such forms are easily distinguished due to large, 25 $36(42) \times 20-31 \mathrm{mkm}$, polygonal, angulate, colourless to yellow and brownish, gemmae, exceptionally with the traces of violet pigmentation; thin-walled cells almost without trigones; stem about 10 cells high with very weak dorsiventral differentiation of the medulla, often blackish ventrally; violetish fuscous bases of rhizoids. Such small forms of the species may be easily missed when they grow in small quantity among other hepatics. 


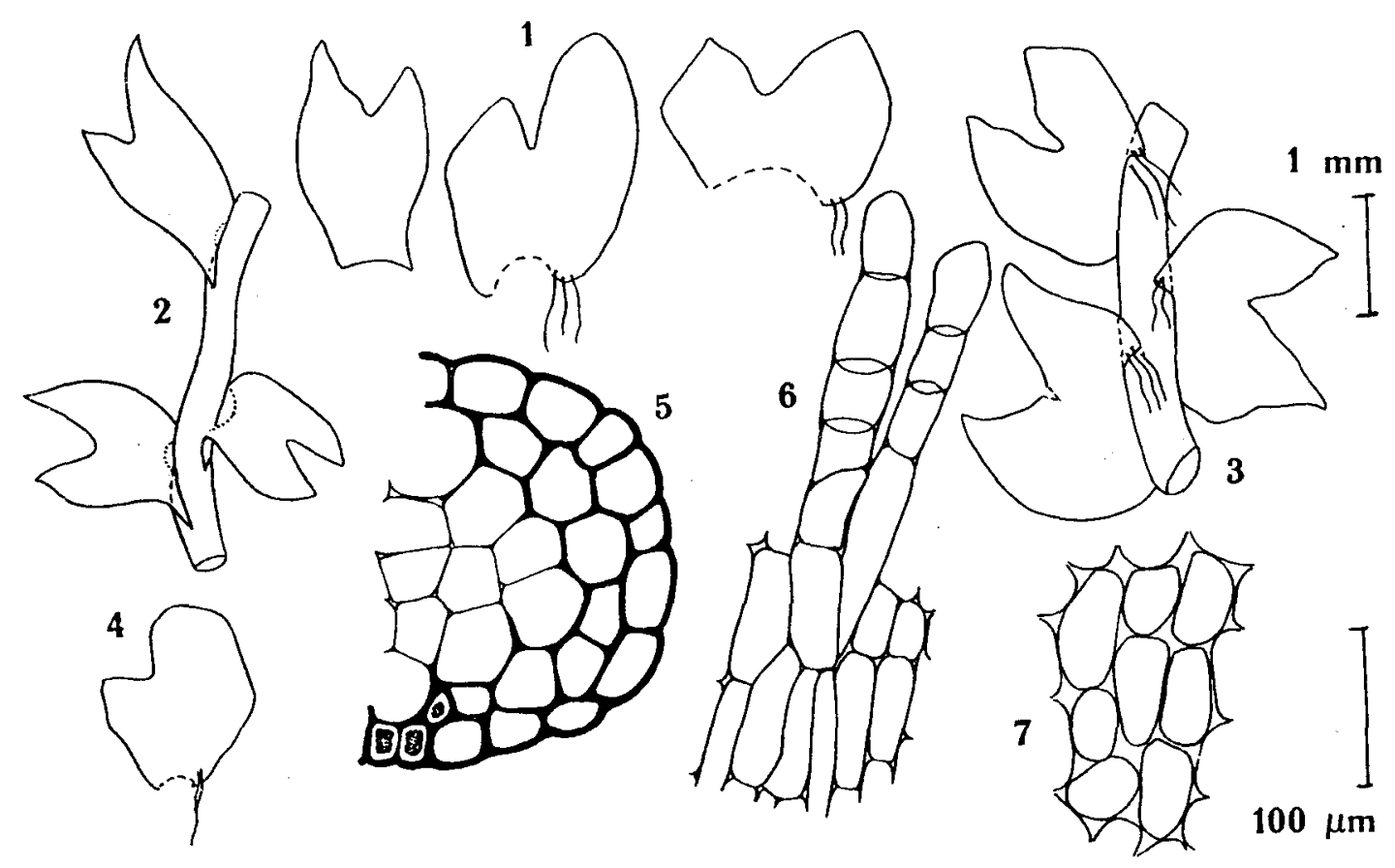

Fig. 5. Gymnocolea fascinifera. 1 - Leaves; 2 - Sector of shoot of mod. angustifolia, antical aspect; 3 - Sector of shoot of mod. latifolia, postical aspect; 4 - Male bract; 5 - Cross section of stem with unusually thick-walled cortical cells; 6 - Underleaf on stem; 7 - Median cells. Scale bars: $1 \mathrm{~mm}$ - for 1 - 4; $100 \mathrm{mkm}-$ for 5 - 7. 1-3, 5-7 - from Kharasavey; 4 - from Belyy.

\section{Grmnocolea (Dum.) Dum.}

Gymnocolea fascinifera Potemk. sp. nov. (Cladopodiella fluitans auct. non (Nees) Buch p. p. - Zhukova \& Rebristaya 1986) (Figs. 5, 6).

Species Gymnocoleae boreali (Frisv. \& Moen) Schust. pigmentationis secundariae magnitudine ac charactere similis est, a qua rhizoidibus fasciculatis a basibus ventralibus foliorum et partibus caulis adjantibus abeuntibus, foliis manifeste inaequilobatis integerrimis, papillis mucosis dentibusque marginalibus destitutis, haud inunctis, guttis oleosis numerosioribus minoribus, plerumque 4- $6 \mathrm{mkm}$ in diam, (2)5-12(16) in quavis cellula locatis, caule pro more tenuiore (cellulis $(5) 6-8(11)$ in diam.), cellulis cor- ticalibus leptodermaticis latioribus (20)23 28 (30) $x(45) 55-110(145) \quad \mathrm{mkm} \quad \mathrm{ad}$ (28) $30-34(38) \times 30-40 \mathrm{mkm}$ in parte caulis dorsali sitis differt.

Plants green to brown, not glistening, 1 $2.5 \mathrm{~mm}$ wide and $5-15 \mathrm{~mm}$ long, often furcate terminal and rarely ventral and lateral intercalary branched. Stem (5)6 - 8(11) cells high; cortical cells weakly differentiated from cells of medulla, rather thin-walled, usually strongly elongated, dorsally (20) 23 $28(30) \times(45) 55-110(145) \mathrm{mkm}$, but sporadically subisodiametric and then wider, (28) $30-34(38) \times 30-40$ mkm. Rhizoids sparse, in more or less distinct fascicles from ventral leaf base and adjacent part of stem (leaves detach with rhizoids). Leaves usually asymmetric with shorter and narrower antical 


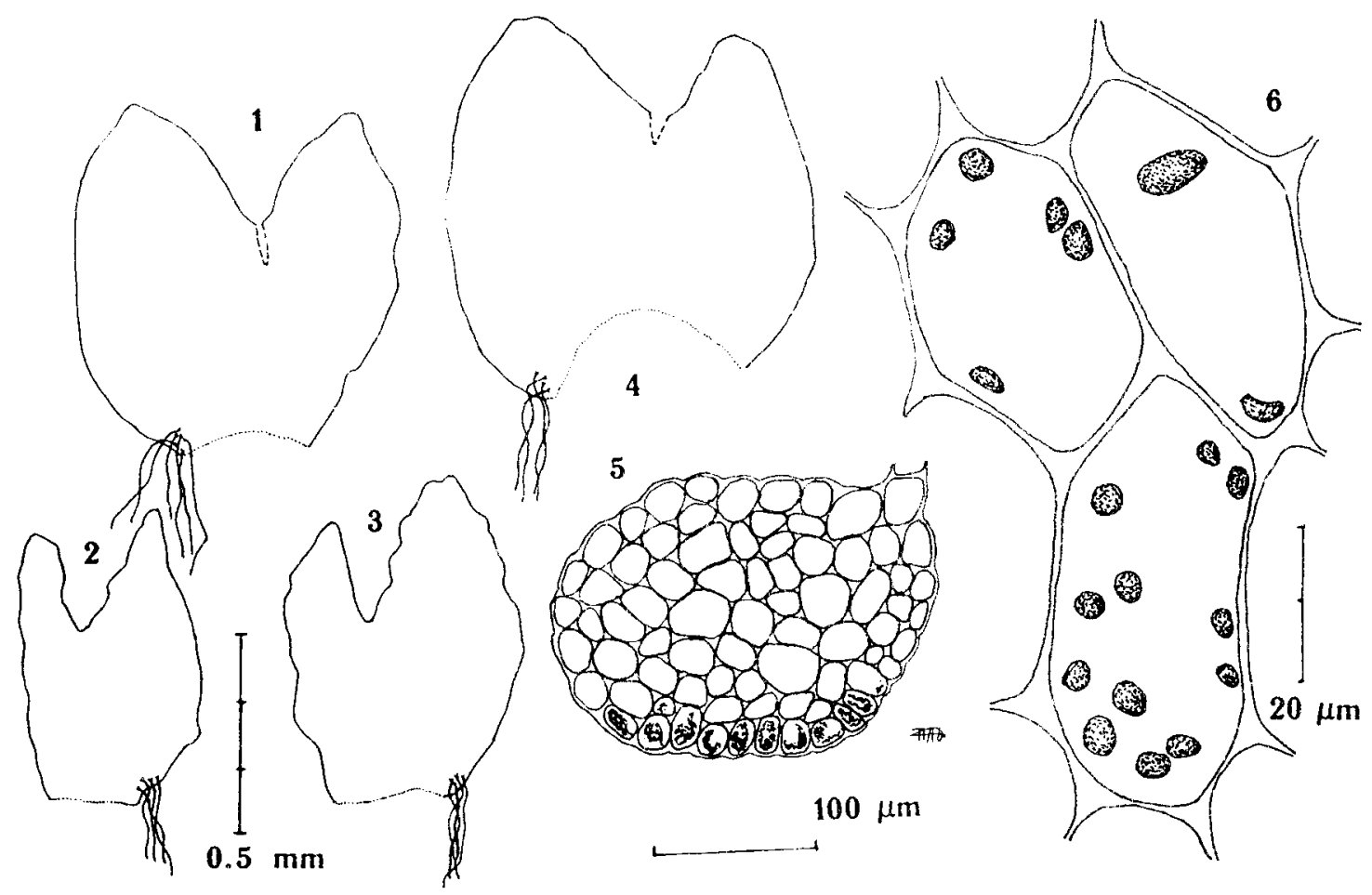

Fig. 6. Gymnocolea fascinifera. 1-4 - Leaves; 5 - Cross section of stem; 6 - Median cells with oil-bodies. Scale bars: $0.5 \mathrm{~mm}$ - for 1 - 4; $100 \mathrm{mkm}$ - for $5 ; 20 \mathrm{mkm}$ - for 6 . All from the holotype.

lobe, widest in the middle third, more often a little longer than broad, but in general very malleable in respect of width/length ratio, which is ca. 1:0.7 - 2.0; sinus wide, $\mathrm{V}$ - or $\mathrm{U}$ shaped, ca. $1 / 3-1 / 2$ the leaf length; lobes from acute to apiculate, with 1 - celled apiculus formed by subisodiametric cell, to obtuse and rotund; margins entire, occasionally more or less crooked, without any teeth or slime papillae. Amphigastria small, onlyoccasionally discernible, mainly when purple pigmentation developed, formed of two stalked slime papillae. Cells more or less thin-walled, with small concave-sided to conspicuously bulging trigones, variable in size: marginal (tangentially measured in distal half of leaf) $17-31 \mathrm{mkm}$, median and basal $18-36 \times 23-45(55-70) \mathrm{mkm}$. Oil-bodies small, granulate, spherical, $4-6(7.5) \mathrm{mkm}$ in diam., exceptional individuals oval, up to 7-9 x 5- $6 \mathrm{mkm}$, (2) 5-12(16) per cell. Cuticle smooth to usually striolate.

Dioicous. Androecia long, spicate. Male bracts strongly concave, very asymmetric, with small antical lobe, $1-2$ - androus. Female plants unknown.

Holotype: USA, Alaska, Seward Peninsula, south Killeak Lake, in well developed troughs of high centered polygon, with Scapania paludicola, July 28, 1992 A. D. Potemkin, coll. $\mathrm{N}^{\mathrm{O}} 92-9701$ (LE).

Besides the type locality where the species was collected at first in fresh state, with oilbodies, it is known from one more locality in Alaska, north of the Seward Peninsula, neighbourhood of Kotzebue (with androecia) (Potemkin 92 - 132 03) and from the following places in Yamal:

AT: Belyy I, Kharasavey II; NT: Matyuiyaha I; ST: Khutyyaha I, Er'yaha I.

In Sphagnum tussock bog and bogs with flowing water, in herb-willow, grass-cotton grass and sedge-lichen-moss tundras, often among Drepanocladus and Sphagnum, with Scapania paludicola var. rotundiloba, Ptilidium ciliare, Pseudolepicolea fryei, Barbilophozia kunzeana, B. binsteadii, Gymnocolea inflata, Odontoschisma elongatum, Ble- 
pharostoma, etc. Once with androecia (Belyy).

Gymnocolea fascinifera may be confused with the other species of the genus and with Cladopodiella fluitans. It differs from all of them in rhizoid position in the ventral leaf base area - a unique feature, not found in the other northern species of Lophozioideae (even if only few rhizoids present at least some of them detach with the leaf base). The rhizoids, detaching with the leaf base, are absolutely noncharacteristic for $G$. inflata and $C$. fluitans and only individual rhizoids occasionally may be detached with the leaf base of $G$. borealis. Besides this character $G$. fascinifera differs from $G$. inflata in its leaf cells with more numerous oil-bodies, mostiy yellowish brown coloration of pigmented forms (never fuscous black), leaves usually with distinctly unequal, sometimes apiculate lobes and the often larger size of plants; from $G$. borealis - in leaves with distinctly unequal lobes and entire margins without slime papillae and teeth, not glistening appearance, numerous oil-bodies ((2) 5 - 12(16) vs $1-6(8)$ per cell), often thinner stem and thin-walled wider cortical cells, and ecological behaviour. The principal feature, differing G. fascinifera as well as the other species of the genus from Cladopodiella fluitans is the presence of terminal furcate branching. Moreover the species under consideration has usually smaller, collenchymatous cells and only sporadic small amphigastria.

Gymnocolea inflata (Huds.) Dum. var. inflata (G. inflata var. heterostipa (Carr. \& Spruce) K. Muell., Cladopodiella fluitans auct. non (Nees) Buch p.p. - Zhukova \& Rebristaya 1986; Andrejeva 1981)

AT: Belyy II, Tambey I, Kharasavey I; NT: Matyuiyaha 11, Bovanenkovo 3, Tomboltosyo III, Mantyto III, Yuribeitoyaha I, Khakhayayaha I; ST: Khutyyaha IV, Khevesyo III, Laptayaha I, Kharangyneto 4, Er'yaha II, Khadytayaha 6.

In sedge, cotton grass and sedge-moss bogs, sedge-lichen, cotton grass and diverse moss tundras, late snow areas. Plants with caducous perianth and androecia rather frequent.

The speceis is malleable. On bare exposed soil it develops mod. latifolia-densifolia-col- orata, or more rarely - mod. parvifolia-laxifolia-colorata and mod. angustifolia-laxifoliacolorata; growing in moss tufts - mod. laxifolia-angustifolia-viridis and mod. parvifolialaxifolia-viridis.

Gymnocolea inflata var. acutiloba (Kaal.) S. Arn.

NT: Tomboilosyo I, Sebayaha I; ST: Khutyyaha II.

Usually on thinly turfed ground or on peat in pools of diverse, mostly sedge and cotton grass bogs and wet tundras, once in sedgelichen nival tundra, associated with Cephalozia bicuspidata, Lophozia ventricosa s.l., Nardia insecta, Odontoschisma elongatum, Scapania hyperborea, S. tundrae, Gymnomitrion apiculatum, etc. Sporadically with sterile perianths, once with traces of gemmae.

After investigation of Yamal and South Greenland material (Schuster \& Damsholt 82 - 1047, 82 - 1118, 82 - 1203, 82 - 1505, 82 - 1817, 82 - 2016, etc.) I have accepted Schuster's and Damsholt's interpretation of "Gymnocolea acutiloba" (Schuster 1988) but treat it here as a variety because we have not enough data on its distribution to say about subspecies. Their interpretation gave a set of new characters of this taxon in the Arctic (distinctive as well as shared with var. inflata): often purplish pigmentation; caducous perianth, pluristratose in basal half with longer teeth of the mouth, $1-2(3)$ cells long; leaves usually widest below the middle; leaf bases sporadically with tooth; ca. $5 \%$ of cells with $1-2$ large oil-bodies, $50-70 \%$ of cells with $3-7$ oil-bodies. Moreover $G$. inflata var. acutiloba may develop rather thick-walled leaf cells with distinct, sometimes bulging trigones and reproduce via gemmae. Unfortunately most of these criteria are not constant, occur in diverse combinations and often it is not easy to separate var. acutiloba from var. inflata because of the overlapping of their variability ranges. Nevertheless typical $G$. inflata var. acutiloba may grow on bare soil and in helophytic condition, among Sphagnum for instance (Schuster 1988), that means it is a distinct genetic entity.

It is necessary to stress that the Arctic 
phases of var. acutiloba are more plastic in cell size, which in the middle of the leaf is (17) 20 - $28 \times 23-31$ (35) mkm usually, and, consequently, often have cells larger than the plants described from temperate regions.

Somewhat tentatively I assign to var. acutiloba the plants from Sebayaha. They share with this taxon size, leaf shape, character of pigmentation, smooth cuticle, but differ from it in larger cells (median leaf cells $28-35$ mkm wide, cortical - $21-30 \mathrm{mkm}$ wide) and lustrous appearance, sporadic stalked slime papillae near leaf and particulary bract base (in typical plants - teeth), longer teeth of perianth mouth composed of $2-4$ superimposed cells. I think it may be a polyploid derivative of var. acutiloba. For clarification of the true taxonomic position of these plants an additional material is necessary.

Because of the presence of slime papillae near the leaf base, the long teeth of the perianth mouth, and large cells and lustrous appearance, these plants may be confused with Gymnocolea borealis. They differ from this species in fuscous black pigmentation often with traces of purple pigment, smaller size, smooth cuticle, caducous perianth and ecological behaviour.

TrITOMARIA Schiffn. ex Loeske

For characteristcs and differentiation of the taxa of Tritomaria in Yamal, grounds for rejection of sectio Tritomaria and sectio Trilophozia (Schust.) Schust. and $T$. exsectiformis subsp. arctica Schust. as well as for description of sporophytes of $T$. heterophylla and androecia of $T$. quinquedentata f. gracilis see Potemkin (1990d).

Tritomaria exsectiformis (Breidl,) Schiffn. ex Loeske s.l. (incl. subsp. arctica Schust.)

NT: Matyulyaha I, Tomboitasyo I, Neromayaha I, Lyakkotosyo II; ST: Khevesyo I, Er'yaha I.

In diverse moss and moss-lichen tundras, individual shoots and tufts among mosses, as an exception on bare soil among lichens, with Barbilophozia binsieadii, Anastrophyllum minutum, Lophozia ventricosa s.l., Ptilidium ciliare, Tritomaria quinquedentata and Blepharostoma. Always with gemmae
Tritomaria scitula (Tayl.) Joerg.

AT: Belyy II (Zhukova \& Rebristaya 1987), Khabeiyaha I: NT: Neromayaha I, Yuribeitoyaha III.

In willow-Dryas tundras and horse-tail willow stands with Lophozia heterocolpos, Blepharostoma, Scapania cuspiduligera, S. gymnostomophila, Barbilophozia quadriloba, Tritomaria quinquedentata, Arnellia fennica, etc. Always with gemmae.

Tritomaria heterophylla Schust. f. heterophylla

NT: Khakhayayaha I; ST: Khevesyo III, Laptayaha III.

Usually on spots in wet moss spotty tundras with Blepharostoma, Nardia geoscyphus, Cephalozia pleniceps, 'Barbilophozia quadriloba, Arnellia fennica, Lophozia grandiretis, Jungermannia polaris, J. obovata, Anastrophyllum minutum, Tritomaria quinquedentata, etc. Almost always with gemmae; male and perianth bearing plants rather frequent; seen twice with mature capsules. Potemkin (1990d, fig. 1) provides the illustration of this form by material from Yamal.

Tritomaria heterophylla f. anomala Potemk. (Bot. Zhurn. 75(12): 1746, 1990)

- ST: Khevesyo II.

On spots in sedge-lichen dwarf shrub-moss, grass-moss and lichen-moss tundras. The set of associated species is similar to that of type form. Once f. heterophylla and f. anomala were found near each other, but in somewhat different microhabitats. With gemmae, perianths and androecia.

The most characteristic features of this form are fuscous black secondary pigmentation; often obtuse to rotund leaf lobes; non gibbous sinuses; comparatively small trigones; female bracts with entire margin and obtuse to shortly apiculate lobes; subentire perianth mouth with obtuse apices of marginal cells; fuscous to violet fuscous, often strongly angulate and then larger gemmae, (20) $25-40(48) \times 17-40 \mathrm{mkm}$. Potemkin (1990d, fig. 1) provides the illustration of this form by material from Yamal.

Tritomaria quinquedentata (Huds.) Buch

Damsholt (1982) and Schuster (1988) distinguish, on the base of perianth characters, two Holarctic subspecies of Tritomaria quin- 
quedentata - subsp. quinquedentata and subsp. turgida (Lindb.) Damsh. Analysis of Siberian material of the species shows, however, that proposed distinctive characters, i.e. perianth mouth ciliate vs shortly dentate; perianth unistratose and plicate on the most of its length vs bistratose at least to the middle and weakly plicate in upper part; purplish pigmentation absent vs present; cells small vs large, etc. occur in diverse combinations and do not provide a foundation for separating "subsp." turgida from "subsp." quinquedentata (see for instance the description of the perianth of $T$. quinquedentata var. quinquedentata f. gracilis below). Therefore, following Schljakov (1980) I do not distinguish var. or subsp. turgida and include it in var. quinquedentata.

Tritomaria quinquedentata var. quinquedentata f. quinquedentata ( $T$. heterophylla auct. non Schust. - Zhukova \& Rebristaya 1986; Gribova \& Potemkin 1988)

\section{AT V; NT IV - V; ST: IV - V.}

In wet, mainly moss, tundras, moss bogs, occasionally in late snow areas. Male and perianth bearing plants sporadic; seen once with mature capsules.

Tritomaria quinquedentata var. quinquedentata f. gracilis Schust.

AT: Belyy I, Khabeiyaha II, Tambey II; NT: Tiutey I, Bovanenkovo I, Neromayaha IV, Mantyto I, Marre Sale I, Saleteyaha 5, Yuribeitoyaha II, Khakhayayaha II, Lyakkotosyo II; ST: Khutyyaha I, Khevesyo II, Laptayaha $I$.

On steep herb slopes, in spotty tundras, $\alpha$ casionally in moss bogs. Perianths and androecia very rare. Androecia from shortly to longly spicate, composed of 3 to 12 pairs of 1 - 2 - androus bracts; antheridia on 1 seriate stalk (17) $20 \mathrm{mkm}$ in diam. Only one plant with perianth has been seen. Female bracts similar to sterile leaves but a little broader than long. Bracteole equal to bracts in length, lingulate, apiculate, coherent with them at base. Perianth pluriplicate, 2 - 3 stratose at base, unistratose on the most of its length; its mouth lobulate, crenulate with solitary 1 - 2(3) - celled teeth ("var. turgida" type!).

This form of the species is most characteristic for "difficult sites". Smallest phases of it may develop the individual bilobed leaves, which are not typical for the species. Potemkin (1990d, fig. 2) provides the illustration of this form by material from Yamal.

Tritomaria quinquedentata var. grandigemma Potemk.

[T. quinquedentata var. grandigemma Potemk. Bot. Zhurn. 75(12):1748, 1990 , nom. invalid. (sine holotypo). Holotypus: Paeninsula Jamal, regio ripae sinistrae fl. Laptajaha adjacens $\left(68^{\circ} 20^{\prime}\right.$ lat. bor., $73^{\circ} 15^{\prime}$ long. orient.) in tundra Nanobetulosocaricosa muscosa, paludosa tumulis et demissionibus tecta, 23.VII.1979, O.V. Rebristaja (LE)] (Tritomaria quinquedentata auct. non (Huds.) Buch - Zhukova \& Rebristaya 1986).

AT: Kharasavey I; NT: Matyuiyaha I, Tiutey l, Bovanenkovo 1 , Sebayaha I, Khakhayayaha II; ST: Khutyyaha II, Khevesyo II, Laptayaha II, Er'yaha I.

In diverse moss, moss-lichen and dwarf shrab tundras. Often with gemmae; perianths and androecia rather rare.

The taxonomic status of var. grandigemma remains somewhat problematic. This variety is characterized by frequent production of comparatively large, ca. (17)22-29(31 34) $\times 16-20(25) \mathrm{mkm}, 1-2(3-4)$ - celled gemmae and leaves with strongly gibbous sinuses. On the other hand the plants are usually subpellucid with cell size and oil-body number a little larger than in the type variety sensu stricto and somewhat resemble in this respect "var. turgida", the gemmae of which have never been described. I have, however, also never seen the gemmae of var. quinquedentata and, consequently, certain doubts arise about the constancy of their size, $15-20 \mathrm{mkm}$, which listed in all known literature.

This taxon as well as the type variety is polymorphous and varies from mod. grandifolia-laxifolia-viridis to mod. parvifolia-subangustifolia-subaequiloba-colorata. Plants of mod. parvifolia-densifolia-subaequiloba-colorata-gemmipara resemble very much Tritomaria heterophylla. They differ from this species in gemmae with usually round, weakly projecting angles (if the gemmae have acute, strongly projecting angles then cell walls in angles are weakly thickened); 
smaller cells in leaf lobes (excepting the leaves with reduced lobes, resulting from intensive gemma production); somewhat less symmetric leaves; different type of the perianth mouth (ciliate-dentate vs crenulatedentate). Potemkin (1990d, fig. 2) provides the illustration of this variety by material from Yamal.

\section{ANASTrophyllum (Spruce) Steph.}

Anastrophyllum saxicola (Schrad.) Schust.

AT: Tambey II; NT: Matyulyaha I, Mantyto I; ST: Khevesyo I, Kharangyneto 2.

In sedge-lichen, often wet tundras and in frost clefts and depressions of polygonal-frost cleft tundra, associated with Barbilophozia binsteadii, B. kunzeana, Ptilidium ciliare, Tetralophozia setiformis, etc. See also Potemkin (1990a).

Anastrophyllum sphenoloboides Schust.

NT: Matyulyaha I, Neromayahn I, Mantyto I, Lyakkotomyo I; ST: Khutyyaha I, Laptayaha I.

In wet moss and dwarf shrub-lichen nival tundras, on steep slope; growing in moss tufts associated with Anastrophyllum minutum, Barbilophozia binsteadii, Lophozia ventricosa s.l., Ptilidium ciliare, etc., but on thinly turfed soil - with Cephalozia bicuspidata, Pleurocladula albescens, Anthelia juratzkana, Calycularia laxa and Gymnocolea inflata. With gemmae, perianths and mature capsules.

The species rather often occurs on thinly turfed soil as mod. parvifolia-colorata-gemmipara. The plants of this modification are very small, $0.2-0.4 \mathrm{~mm}$ wide and $2-4 \mathrm{~mm}$ long, with thinner stem, $6-7$ cells high; scattered and short teeth of perianth mouth, 1 (2) cells long; antheridia on 1 - or 2 seriate stalk; gemmae $1(2)$ - celled, 14 - 20 (23) $\times 12$ - $17 \mathrm{mkm}$, from round to 3 - 4 angulate, mostly with weakly projected angles, from faintly to deep purple; gemmiparous leaves usually strongly modified, dentate, as in Lophozia bicrenata (see Potemkin 1993b). Deviations from the description of the species by its author (Schuster 1969; Schuster \& Damsholt 1974) that are mentioned above result mainly from the unfavorable conditions for growth on bare soil. Predominantly 1 - celled gemmae and modified gemmiparous leaves result apparently from very abundant gemma production.

Anastrophyllum sphenoloboides may be confused with some forms of $A$. minutum developing purplish pigmentation. Such forms, however, have features typical of $A$. minutum: wide leaves, usually not longer than broad, with wide sinus; small, not prominent trigones and marginal cells considerably smaller than median.

Anastrophyllum minutum (Schreb.) Schust. var. minutum f. minutum

AT V; NT V; ST V.

The most common Yamal hepatic, occurring in diverse moss tundras, where it is more frequent among Dicranum, rarer in lichen and spotty tundras, and exceptionally on steep slopes. Sporadically with gemmae, perianth and androecia.

A polymorphous taxon. The most parodoxical deviations from phenotypes described earlier are phases from dry sites with Anastrophyllum michauxii-like squarrose antical lobes, that resemble very much $A$. japonicum Steph. phenotypes of $A$. michauxii. There are numerous transitional forms between these phases and typical $A$. minutum, however. The smallest phenotypes were found on exposed bare soil. They are only $0.25 \mathrm{~mm}$ wide and 2 - 3 mm long. Plants of mod. parvifoliasublaxifolia-colorata somewhat resemble Cephaloziella arctica, of mod. parvifolia-densifolia-colorata - Gymnomitrion.

Anastrophyllum minutum var. minutum f. cuspidata (Kaal.) Schust.

AT: Belyy I; NT: Matyulyaha I, Bovanenkovo 1, Neromayaha III, Mantyto I, Marre Sale I, Yuribeitoyaha I, Khakhayayaha I, Lyakkotosyo II; ST: Khutyyaha III.

In wet and shade sites among mosses and lichens in diverse communities characteristic for the type form.

Anastrophyllum minutum var. grandis (Lindb.) Schust.

AT: Khabeiyaha I, Tambey II; NT: Matyuiyaha I, Tombaitosyo II, Neromayaha II, Manty to I, Marre Sale II, Yuribeitoyaha III, Khakhayıyaha II; ST: Khevesyo II, Laptayaha II, Kharangyneto 2, Er'yaha II.

In diverse tundras characteristic for the type variety, occasionally together with it. Schljakov (1980) noted that it is a form of 
wet sites with comparatively poor nourishment. In Yamal, however, var. grandis is often associated with basiphilous taxa. For instance, in Yuribeitoyaha it was collected with Scapania cuspiduligera, S. praetervisa, Tritomaria scitula, Lophozia heterocolpos, $L$ major, Odontoschisma macounii, etc. Once (Laptayaha) with gemmae. Gemmae 3 angled to polygonal, brownish red and colourless mixed, $16-20(23)$ x $14-17(20)$ mkm.

This variety may be easily confused with Anastrophyllum cavifolium. It differs from this species in its small marginal leaf cells, which usually considerably smaller than median and often form a discrete border; more narrow cortical cells; rather regular, in crescentic rows, cell position in leaf lobes; not distinct, smaller trigones; fewer oil-bodies, etc. Unfortunately the separation of both taxa is complicated by occurrence of transitional forms with features of both taxa (cf. Zinovjeva 1969). So var. grandis may develop very concave and individual 3 - lobed leaves as well as very thick stems, to 14 cells high, etc.

Anastrophyllum cavifolium (Buch \& S. Arn.) Lammes

AT: Kharasvey I; NT: Neromayaha I, Mantyto I.

In moss (Dicranum) tundras, on tussock in yernik-sedge tussock bog with Ptilidium ciliare, Anastrophyllum minutum, Tritomaria quinquedentata, Barbilophozia kunzeana, Blepharostoma, etc.

Subfam. MESOPTYCHIOIDEAE Schust.

MESOPTYCHIA (Lindb.) Evans

Mesoptychia sahlbergii (Lindb. \& H. Arn.) Evans

ST: Khutyyaha 1.

In moss willow stand among Drepanocladus sp. and Paludella squarrosa with Lophozia gillmanii, $L$ heterocolpos var. arctica, Plagiochila porelloides, Aneura pinguis, etc.

Subfam. JUNGERMANNIOIDEAE

JUNGERMANNIA L.

Subgen. JUNGERMANNIA

Jungermannia pumila With.

ST: Khevesyo I.

In moist dwarf shrub-sedge-moss tundra on bare soil with Cephalozia bicuspidata and Nardia geoscyphus.

Jungermannia polaris Lindb.

AT: Belyy I, Khabeiyaha I, Tambey II, Kharasavey I; NT: Tiutey 1 , Yuribeitoyaha I, Khakhayayaha I; ST: Khevesyo I, Laptayaha If, Er'yaha I.

On spots in spotty tundras, rarely on bare soil on herb and nival slopes. Often with perianths, occasionally with mature capsules.

\section{Subgen. Solenostoma (Mitt.) Amak.}

\section{Jungermannia confertissima Nees}

AT: Tambey I; NT: Tomboitosyo I, Neromayaha I, Khakhayayaha 1; ST: Khevesyo II, Laptayaha II, Er'yaha I.

On bare and thinly turfed soil in spotty lichen-moss tundras, wet herb-moss willow stands, on nival slope; associated with $\mathrm{Nar}$ dia geoscyphus, Cephalozia bicuspidata, $C$. pleniceps, Aneura pinguis, Blepharostoma, Lophozia grandiretis, Odontoschisma macounii, Tritomaria heterophylla, Cryptocolea imbricata, Anthelia juratzkana, etc. Often with perianths, once with mature capsules.

Jungermannia jenseniana Grolle

NT: Khakhayayaha I; ST: Khevesyo II.

On spots of bare sandy ground in spotty dwarf shrub tundras with Anthelia juratzkana, Marsupella sprucei, Prasanthus suecicus, Cephalozia bicuspidata, Nardia geoscyphus, etc. Twice (Khevesyo) with perianths.

Yamal material of Jungermannia jenseniana is too sparse to form a true notion on this species. Phases without distinct red pigmentation are difficult to separate from $J$. sphaerocarpa var. nana also developing a perigynium. Differentiation from $J$. confertissima is more problematic. The main distinctive feature of the last species is rhizoid position. This character, however, is not very constant - rhizoids may migrate to ventral leaf base and perigynium in some forms of $J$. sphaerocarpa var. nana (Schuster \& Damsholt 1974) and, moreover, in $J$. jenseniana itself - in an isotype of the species from JE (V. Schiffner. Hepaticae eur. exs. 1380. Aplozia pusilla C.Jens. Orig. Ex.!) leaves often detach with rhizoids. As a consequence, the problem of taxonomic status of $J$. jenseniana is critical. 
Jungermannia sphaerocarpa Hook. var. sphaerocarpa

AT: Beiyy I, ST: Khevesyo III, Laptayaha I.

On bare ground of creek, river and lake banks with Pleurocladula albescens, Cephaiozia bicuspidata, Nardia geoscyphus, Lophozia of. savicziae, Lo opacifolia, Anthelia juratzkana, Blasia pusilla, etc. Almost always with perianths, once with mature capsules.

Jungermannia sphaerocarpa var. nana (Nees) Frye \& Clark (Solenostoma pumilum subsp. polaris auct. non (Lindb.) Schust. Zhukova \& Rebristaya 1986)

AT: Belyy I, Tambey II, Kharasavey II; NT: Matyulyaha II, Neromayaha I, Yuribeitoyaha I, Khakhayayaha II; ST: Khevesyo IV, Laptayaha I.

On spots of bare ground in wet spotty tundras, rarer at the foot of steep herb and nival slopes and on banks of creeks and lakes. Almost always with perianths, often with mature capsules.

Small forms of Jungermannia sphaerocarpa var. nana. are sometimes confused with $J$. polaris. They differ from the last species in their larger cells, especially marginal, which near leaf apex are at least $20-23(25) \mathrm{mkm}$ (vs $15-17$, rarely $21 \mathrm{mkm}$ long in $J$. polaris); subrotund, plane or slightly concave, or, occasionally, weakly deflexed backward leaves, briefly decurrent dorsally and ventrally, oriented in parallel to stem and, consequently, jutted out of the ventral surface of the ster (in J. polaris leaves mostly ovate, widest at base, nondecurrent, concave, oriented distinctly at the angle to stem and never jutted out of the ventral surface of the stem).

Jungermannia sphaerocarpa var. nana in Yamal often develops a distinct low perigynium and the gametophyte lacks red or purplish pigmentation while capsules and spores are usually purplish or purplish brown.

The taxonomic status of Jungermannia sphaerocarpa var. nana is rather problematic. Quite possibly it is mainly an ecologically determined form of tundra and alpine regions (cf. Schuster 1969; Koponen et al. 1977).

\section{Subgen. PlectocoleA (Mitt.) Amak.}

Jungermannia hyalina Lyell (Solenostoma pumilum auct. non (With.) K. Muell. Zhukova \& Rebristaya 1986)

AT: Khabeiyaha I, Kharasavey I; NT: Matyulyaha II, Saletayaha 1, Khakhayayaha II; ST: Khutyyaha H, Khevesyo II, Er'yaha I.

In herb-moss, herb-horse-tail and sedge willow stands, at the foot of steep herb slope at margin of swampy sedge depression, on sandy bank, on degraded Sphagnum. Androecia, perianthas and mature capsules rare. Reports of the species from the arctic tundra are northernmost known.

In Yamal Jungermannia hyalina occurs as mod. Laxifolia-lepioderma-viridis, more rarely - mod. laxifolia-mesoderma- subcolorata vel viridis. The plants have pellucid, often strongly asymmetric leaves, longly decurrent dorsally; mostly colourless rhizoids, not rarely in distinct fascicles from ventral leaf bases; thin-walled medulla of stem; and sporadically rather low perigynium. While these characters are usually not mentioned for the species, they often occur in $J$. hyalina throughout its range (as was found in the course of investigation of numerous collections of the species in LE).

Jungermannia obovata Nees s.l. (Jungermannia subelliptica (Lindb. ex Kaal.) Lev.)

AT: Khabeiyaha II, Kharasavey II; NT: Neromayaha I; ST: Khutyyaha I, Khevesyo III, Laptayaha II, Er'yaha I.

In dwarf shrub sedge-(cotton grass)-moss sedge-lichen-moss and diverse spotty tundras, on wet thinly turfed loamy soil near temporary water courses, in late snow areas, usually on thinly turfed soil, associated with Anthelia juratzkana, Nardia geoscyphus, Jungermannia polaris, $J$. sphaerocarpa var. nana, Cephalozia bicuspidata, C. pleniceps, Scapania obcordata, Tritomaria heterophylla, etc. Almost always with perianths, often with mature capsules.

\section{NARDIA S.Gray}

Nardia japonica Steph.

ST: Khutyyaha 1.

In dwarf shrub-cotton grass moss tundra and on high-centered polygon, on bare loamy sandy soil with humus, associated with Cephalozia bicuspidata, Gymnocolea inflata 
var. acutiloba, Calycularia laxa and Nardia insecta. Only male plants were found.

When the species grows with Nardia insecta it distinctly differs in smaller size $(0.2-0.5$ $\mathrm{mm}$ vs $0.5-1.6 \mathrm{~mm}$ wide); underleaves, which longer than the half of leaf length vs considerably shorter than the half of leaf length; and sex distribution (dioicous vs paroecious).

Nardia geoscyphus (De Not.) Lindb. var. geoscyphus

AT: Belyy II, Khabelyaha II, Tambey II, Kharasavey III; NT: Matyulyaha I, Tlutey 1, Neromayaha IV, Saletayaha 4, Yuribettoyaha I, Khakhuyayaha III, Lyakkotosyo I; ST: Khutyyaha III, Khevesyo V, Laptayaha V, Er'yaha I.

In moist, more rarely in comparatively dry spotty tundras, on steep herb and nival slopes, on banks of diverse water courses and lakes, in bog communities; on sandy, loamy and peaty ground. The most common species of Jungermannioideae on the peninsula. Often with perianths and mature capsules.

Nardia geoscyphus var. bifida Schust.

NT: Neromayaha I.

On loamy sand landslip nival slope with Anastrophyllum minutum.

Nardia insecta Lindb.

NT: Mantyto I; ST: Khutyyaha II.

On high-centered polygon, yernik Sphagnum hummock and polygonal spotty- hummock dwarf shrub lichen tundra; on loamy and loamy sandy soil with humus, with Cephalozia bicuspidata, Anthelia juratzkana, Gymnocolea inflata var. acutiloba, Jungermannia jenseniana, Gymnomitrion apiculatum, Marsupella sprucei, Nardia japonica and Lophozia ventricosa s.l. With perianths and mature capsules.

Yamal phenotypes of the species are not typical. They usually have oval, rotund to reniform, strongly concave, entire or mostly retuse leaves; very deep pigmentation, from purplish brown to fuscous or purplish black. They share with typical plants paroecia; collenchymatous large cells with granulate oilbodies; distinct squarrose underleaves with rhizoids in fascicles at base, frequently narrowly united with leaf bases on one side of stem; and sporophyte characteristics. Such forms of the species may be confused with Nardia scalaris. They differ from it in sex distribution; granulate, not glistening cilbodies; underleaves mostly connate with leaves bases on one side of stem; often somewhat larger cells. Moreover Nardia scalaris is principally an amphioceanic species. Individual reports of it from continental regions are apparently based on phenotypes of $N$. insecta with entire leaves.

\section{Cryptocolea Schust.}

Cryptocolea imbricata Schust. (Fig. 4: 5-6)

AT: Khabeiyaha I; ST: Khutyyaha I, Khevesyo II, Laptayaha II.

On bare ground in spotty tundras and on herb slopes, usually with Tritomaria heterophylla, Nardia geoscyphus, Jungermannia confertissima, J. obovata, Cephalozia pleniceps, more rarely with Arnellia fennica, Jungermannia sphaerocarpa var. nana, Blepharostoma, Odontoschisma macounii, Tritomaria quinquedentata, Prasanthus suecicus, Gymnomitrion corallioides, and Anthelia juratzkana. Male and female plants not rare. For details see Potemkin (1990a).

\section{Subfam. MYLIOIDEAE Grolle}

\section{MYLin S. Gray}

Mylia anomala (Hook.) S. Gray

NT: Mantyto I; ST: Khutyyaha III, Khevesyo I.

In sedge-Sphagnum tussock-pool swampy tundras, on peat outcrop and on steep herbdwarf shrub nival slope. Usually with $B a r b i-$ lophozia binsteadii, B. kunzeana, Ptilidium ciliare, Cephalozia lunulifolia, C. bicuspidata, Scapania irrigua, Sphagnum spp., etc. Twice with gemmae (Khutyyaha).

In Manty to individual plants of mod. parvifolia-densifolia- colorata were collected on a nival steep slope on bare soil with Pleurocladula albescens, Gymnomitrion concinnatum, Cephalozia bicuspidata, C. pleniceps, Anastrophyllum minutum, and Lophozia of. savicziae. The plants are only $0.8-1.0 \mathrm{~mm}$ wide and about $3 \mathrm{~mm}$ long. They resemble Nardia scalaris rather than Mylia. Such unusual phases of the species differ from Nardia scalaris in the character of cross section of stem with regularly distinctly projecting, larger cortical cells, $60-80 \times 45-60 \mathrm{mkm}$ 
(Schuster 1969, Figs. 260:8, 299:8); larger leaf cells, 48 - $56 \times 28$ - 46 mkm, and underleaves; and not persistent, more numerous oil-bodies of different structure.

\section{GYMNOMITRIACEAE Klinggr.}

Prasanthus (Lindb.) Lindb.

After description of Prasanthus jamalicus (Potemkin 1992b) two species of the genus became known. They differ as follows:

\section{KEY TO SPECIES OF PRASANTHUS}

1. Minute (width of sterile shoots $200-350$ mkm), purplish brown to purplish black, unglistening, with distant leaves on sterile shoots, resembling small species of Nardia; stolons rare; cell walls of sterile leaves thin; basal leaf cells mostly subisodiametric (length : width ratio - $1: 1.5(2)$ ), undifferentiated from median cells; thickenings of inner capsule wall layer nodular, often with semiannular bands in basal parts of valves; elaters $3(4)$ - spiral, exceptionally 2 - and 5 - spiral

..sectio PSEUDONARDIA Potemk., P. jamalicus

1. Small (width of sterile shoots $350-700$ mkm), yellow to brown, very rarely the ventral part of the perigynium purplish; glistening, with imbricate, rarely subimbricate leaves; stolons common; cell walls of leaves thick; basal leaf cells mostly elongated (length : width ratio - $1: 2-3$ ), distinctly differentiated from subisodiametric median cells; thickenings of inner capsule wall layer semiannular; elaters 2 - spiral, exceptionally 3 -spiral.........sectio PRASANTHUS, P. suecicus

Prasanthus jamalicus Potemk. [Ann. Bot. Fennici 29:319, 1992]

NT: Khakhayayaha 1; ST: Khutyyaha I.

In pure patches on exposed windswept sandy soil, in Khutyyaha (Holotype) with small admixture of Scapania sp., Prasanthus suecicus, Marsupella sprucei, Anthelia juratzkana. With mature capsules.

Prasanthus suecicus (Gott.) Lindb.

AT: Belyy II, Khabelyaha III, Tambey II, Kharasavey II; NT: Matyulyaha II, Neromayaha III, Saletayaha 4, Yuribeitoyaha I, Khakhayayaha III, Lyakkotoryo I; ST: Khutyyaha III, Khevesyo IV, Laptayaha III, Kharangyneto $I$, Er'yaha II, Khadytayaha 2.

In spotty and lichen tundras, steep thinly turfed slopes, on exposed windswept sandy soil. Usually fertile, often with mature capsules.

\section{Marsupella Dum.}

Marsupella sprucei (Limpr.) H. Bern.

AT: Khabeyyaha I, Tambey 1; NT: Matyuiyaha I, Neromayaha II, Saletayahe 5 , Khakhayayaha II, Lyakkotosyo I; ST: Khutyyaha II, Khevesyo III, Laptayahe I, Er'yaha I, Khadytayaha 2.

Usually individual plants on windswept sandy soil in spotty tundras, steep slopes, and other similar sites, assoxiated mostly with Prasanthus suecicus and Gymnomitrion corallioides. Almost always fertile, sporadically with mature capsules.

\section{Gymnomirrion Corda}

Gymnomitrion apiculatum (Schiffn.) K. Muell. (G. corallioides auct. non Nees - Gribova \& Potemkin 1988)

AT: Belyy I, Tambey I; NT: Matyuiyaha II, Tomboilosyo I, Saleteyaha 1; ST: Khutyyaha I, Khevesyo 1, Isptayaha 1 .

On nival north-facing sandy slopes, in herb-willow Gymnomitrion and dwarf shrublichen tundras on sandy soil, associated with the other regional Gymnomitriaceae, Anthelia juratzkana, Lophozia cf. savicziae, L opacifolia, Cephalozia bicuspidata, Pleurocladula albescens, and Diplophyllum taxifolium. Once (Matyuiyaha) with perianth.

The species occurs in Yamal in two phases: Gymnomitrion corallioides-like, dorsiventrally compressed, with very dense, often hardly discernible leaves and the other phase, resembling more Gymnomitrion concinnatum, almost not dorsiventrally compressed, with more distant, distinctly discernible leaves. As a consequence it often difficult to identify the species for sure in the course of superficial investigation of specimens under a dissecting microscope, especially because it very rarely develops red pigmentatioin in Yamal. $G$. apiculatum differs from $G$. concinnatum, when sterile, in the shallower and wider, obtuse-angled sinus; thin-walled marginal cells, erose at least on old leaves; smooth cuticle; apiculate lobes, with thin-walled, quickly erose, not permanent apiculi of 2 superimposed cells (in $G$. concinnatum they are thick-walled, not erose, permanent, while 
sometimes very similar in form), etc. The main distinctive features from $G$. corallioides are the following: apiculate leaf lobes (discernible on young leaves); wide sinus; thinner-walled leat cells.

Gymnomitrion concinnatum (Lightf.) Corda

AT: Belyy IIl, Khabeiyahs I, Tambey II; NT: Matyuiyaha II, Tiutey $l$, Mantyto I, Khakhayayaha I; ST: Khutyyaha II, Khevesyo II, Kharangyneto $I$, Er'yaha I, Khady tayaha 3 .

In spotty (often Gymnomitrion) tundras, on steep slopes, late snow areas, etc., on sandy and loamy ground. Male plants and plants with mature capsules sporadic.

Gymnomitrion concinnatum differs from the two other regional representatives of the genus in its narrow and more deep sinus; faintly but distinctly papillose cuticle; and not erose while often decolorate leaf margins. The species varies from mod. subdensifoliaviridis to mod. densifolia-fusca.

\section{Gymnomitrion corallioides Nees}

AT: Belyy IV, Khabeiyaha IV, Tambey IV, Kharasavey III; NT: Matyulyaha 11, Tiutey 2, Neromayaha IV, Marre Sale 1, Saletayaha 10, Yuribeltoyaha 1, Khakhayayaha III, Lyakkotosyo I; ST: Khutyyaha IV, Khevesyo III, Laptayaha II, Kharangyneto 3, Er'yaha II, Khadytayaha 3.

Usually in spotty sedge-lichen and sedgeRacomitrium-lichen tundras, where it is a dominant taxon on spots (in this connection these tundras are named Gymnomitrion or Gymnomitrion-Racomitrium tundras). Male plants and plants with mature capsules are sporadic. The species varies from mod. densifolia-colorata (on exposed sites) to mod. subdensifolia-yiridis (in shade).

SCAPANIACEAE Migula

SCAPANIA (Dum.) Dum.

Subgen. JENSENIA S.Arn.

Scapania obcordata (Berggr.) S.Arn.

AT: Belyy III, Khabeiyaha II, Tambey II; NT: Matyuiyahd I, Bovanenkovo I, Neromayaha II, Yuribeitoyaha II. Khakhayayaha II; ST: Khutyyaha II, Khevesyo III.

In diverse moist moss tundras, near temporary water courses, on steep herb and nival slopes, in sedge-moss bogs with flowing water, and on peat outcrop. Usually with gemmae or with traces of gemmae on modified leaves, sporadically with androecia and perianths.
Scapania obcordata is an extremely variable species, which, when growing on exposed bare soil usually develops mod. parvifolia-subaequiloba-colorata but in shade and moist conditions produces the phenocopies of $S$. irrigua. The latter phenotypes differ from $S$. irrigua in stem anatomy, character of the cell net at base and near apexes of leaves (see Schuster 1974; Schljakov 1981), peculiar modification of gemmiparous leaves, and gemmae and oilbodies characteristics. Oil-bodies in $S$. obcordata are often with a more or less distinct central droplet (Schuster 1974, Fig. 346: 2).

Subgen. KAALAASIA Buch

Scapania gymnostomophila Kaal. f. gymnostomophila

NT: Yuribeitoyaha I.

In cleft on spot in spotty-cleft tundra with Lophozia heterocoipos, L major, Barbilophozia quadriloba f. glareosa, Tritomaria quinquedentata f. gracilis. With gemmae.

Transitional forms to Scapania gymnostomophila f. incurva were found. It confirms the supposition of $H$. Persson (1946) and Schuster (Schuster et al. 1959) that "Diplophyllum incurvum Bryhn \& Kaal." is a peculiar form of Scapania gymnostomophila characteristic for exposed sites.

Scapania gymnostomophila f. incurva (Bryhn \& Kaal.) Schust.

NT: Yuribeitoyaha II.

On bare soil in willow-Dryas spotty tundra with Arnellia fennica, Tritomaria scitula, Lophozia heterocolpos, L. badensis, and Barbilophopzia quadriloba f. glareosa.

Scapania gymnostomophila f. incurva resembles very much $S$. calcicola (H. Arn. \& Perss.) Ingh. subsp. ligulifolia (Schust.) Damsh. \& Long, differing from this taxon in its smaller gemmae and number of oil-bodies which are usually $1-2$ per median cell.

Subgen. BUCHIELLA Schust.

Scapania zemljae S. Arn (? S. invisa Schust.)

AT: Belyy 1; NT: Tomboitosyo 1, Neromayaha III, Khakhayayaha II; ST: Khutyyaha II, Khevesyo II, laptayaha II. 
Usually on spots in spotty tundras, accasionally on thinly turfed sandy soil, associated mostly with Gymnomitrion corallioides, Prasanthus suecicus, Cephaloziella arctica, Anthelia juratzkana, Lophozia alboviridis, L excisa, Marsupella sprucei, Nardia geoscyphus, etc. In Belyy the species was collected, however, in association with mainly basiphilous hepatics: Lophozia heterocolpos var. harpanthoides, Barbilophozia quadriloba, Jungermannia polaris, Cephaloziella arctica, and Odontoschisma macounii. Always with gemmae, occasionally with androecia, once with perianth (Khakhayayaha). For descriptions of male plants and characteristic of gemmae see Potemkin (1993b).

The species is assigned here to subgenus Buchiella rather tentatively. Sterile plants of Scapania zemljae have much in common with the type species of the subgenus - $S$. cuspiduligera: erect and sheathing, often widely $2(3)$ - stratose leaf base; ability to develop a border of smaller thick-walled marginal cells; colourless to red and brown, 2 - celled gemmae; not persistent oil-bodies; decurrent ventral leaf margin, etc. (Widely $2(3)$ - stratose leaf bases have not been noted previously for the species; this character was found during investigation of original collections of 0 . Ekstam from Novaya Zemlya, including the type of the species (Novaya Zemlya, S. Island, Sinus Karmakulski, O. Ekstam, 3.09. 1901) and of Yamal materials). The structure of the perianth (which has been seen only once) is different from that of $S$. cuspiduligera, however. The perianth is pluriplicate in its upper part, with (3) 4 deep plicae descending to the base. The mouth is bleached, dentate, with bluntish to triangular teeth with a uniseriate apiculus of $1-2(3)$ subisodiametric cells; the larger teeth arise from a base $3-4(5)$ cells broad. The perianth characteristics separate $S$. zemljae from $S$. cuspiduligera. But these differences cannot be evaluated firmly on the basis of only one collection. Additional collections of plants with perianths are needed for the elucidation of the taxonomic position of this species.
Scapania cuspiduligera (Nees) K.Muell. var. cuspiduligera

AT: Khabeiyaha I; NT: Matyuiyaha I (Zhukova \& Rebristaya 1986), Marre Sale 2, Yuribeitoyaha III; ST: Laptayaha $\mathrm{I}$.

In herb-moss and horse-tail willow stands, sedge-yernik-willow tundra, associated with Blepharostoma, Tritomaria quinquedentata, $T$. scitula, Lophozia heterocolpos, L major, Barbilophozia quadriloba f. glareosa, Anastrophyllum minutum var. grandis. Always with gemmae, which are 2 -celled and almost invariably yellowish brown with a deeper pigmented septum.

Comparative abundance of the species was mentioned only in Yuribeitoyaha where the manifestations of its variability from common mod. laxifolia-viridis (plants to $10 \mathrm{~mm}$ long and $3 \mathrm{~mm}$ wide) to mod. parvifolia-(densifolia)-colorata (plants about $2 \mathrm{~mm}$ long and $0.7 \mathrm{~mm}$ wide) were observed. Plants of the last modification differ considerably from typical forms as was noted by Schuster also (Schuster et al. 1959). They have deep fuscous (rarely brown) pigmentation; leaves with unequal, occasionally shortly apiculate lobes, sporadically with individual obtuse teeth formed mostly by projecting angles of marginal cells. The border is present only when marginal cells are bleached. Its absence correlates with development of deep fuscous pigmentation. Cells are considerably smaller, median 14 - $17 \mathrm{mkm}$, marginal 10 - $17 \mathrm{mkm}$, occasionally with rough striolate cuticle (elongated papillae to $3-4 \mathrm{mkm}$ wide and $10-15 \mathrm{mkm}$ long). Sheathing of the stem by leaf bases as well as long ventral decurrence are not distinct, especially in mod. densifolia. Such phenotypes are usually connected with typical ones by transitional forms. They have characteristic bleached ventral leaf bases and modified apexes of gemmiparous leaves, brown, 2 - celled gemmae and, accordin $\bar{g}$ to Schuster \& al. (1959), brown, big oil-bodies, (1) 2 - 4(5 - 6) per cell.

Scapania cuspiduligera var. diplophyllopsis Schust.

NT: Neromayaha II.

In yernik-willow and lichen tundras, on loamy soil with humus, associated with Jungermannia obovata, Nardia geoscyphus, 
Anthelia juratzkana, Lophozia jurensis, L. major, L. heterocolpos, Ptilidium ciliare, Blepharostoma, Barbilophozia hyperborea, $B$. quadriloba, Tritomaria quinquedentata, $T$. exsectiformis, Cephaloziella rubella subsp. arctogena. Always with gemmae, once with androecia (for description of androecia see Potemkin (1993b)).

Until now the range of variability and distinctive features of this variety remain not quite clear. A Diplophyllum toxifolium - like ventral lobe is not a constant character. Gemma production often leads to reduction of the ventral lobe, resulting occasionally in leaves with almosi equal lobes. I think, the most important criteria, differentiating this variety from var. cuspiduligera, is the gemmae, green until near maturity, then becoming brown, and leaf lobes often with few, small sharp denticulations and a 1 celled mucro.

\section{Subgen. SCAPANIA}

Scapania curta (Mart.) Dum. var. curta

AT: Belyy I (Zhukova \& Rebristaya 1987), Khabeiyaha I, Tambey I, Kharasavey I; NT: Neromayaha II, Mantyto 1, Yuribeitoyaha I, Khakhayayaha I; ST: Khutyyaha I, Khevesyo II, Laptayaha II, Er'yaha I.

In dwarf shrub-moss and spotty tundras, at the foot of herb and nival slopes, in flatpolygon and sedge-moss bogs, on peat outcrop. Ocasionally with gemmae, once with perianth (Er'yaha).

Scapania curta var. grandiretis Schust.

NT: Khakhayayaha II; ST: Khutyyaha II.

In late snow areas, tussock bog, tussock moss tundra, associated with Tritomaria quinquedentata f. gracilis, Nardia geoscyphus, Jungermastnia conjertissima, Lophozia opacifolia, L of. savicziae, Anthelia juratzkana, Cephalozia bicuspidata, Scapania curta var. curta, etc. Usually with gemmae, once with perianths (Khakhayayaha).

Scapania scandica (H. Arn. \& Buch) Macv. yar. scandica ( $S$. parvifolia Warnst.; $S$. mucronata auct. non Buch - Potemkin 1989)

AT: Belyy II, Khabelyaha II, Tambey III, Kharasavey II; NT: Matyulyaha II, Tomboitosyo I, Neromayaha III, Manty to I, Marre Sale 1, Saletayaha I, Yuribeitoyaha I, Khakhayayaha II; ST: Khutyyaha V, Khevesyo V, Lapayaha III, Kharangyneto 2, Er'yaha II, Khadytayaha $l$.
In diverse tundra communities formed by mosses, lichens, sedges, grasses and dwarf shrubs, on spots in spotty tundras, in late snow areas, occasionally in bogs composed of sedge, cotton grass and mosses (mainly by species of Drepanocladus, Hypnum, Sphagnum). It is the most widespread taxon of the genus in Yamal. Often with gemmae, sporadically with androecia and perianths: For details on this and the other varieties of the species see Potemkin (1993a).

\section{Scapania scandica var. argutedentata Buch}

ST: Khevesyo I.

At base of steep herb slope and on moist loamy scarp with Lophozia opacifolia, $L$ cf. savicziae, Blasia pusilla, Nardia geoscyphus, Jungermannia sphaerocarpa, Anthelia juratzkana, Cephalozia bicuspidata, C. pleniceps, Pleurocladula albescens. With gemmae, androecia, perianths and mature capsules. Illustrations in Potemkin (1993a).

\section{Scapania scandica var. grandiretis (Schljak.) Schljak.} I.

AT: Kharasavey I; NT: Neromayaha 1, Khakhayayaha

On spots in spotty tundras, on margin of lake and in nival tundra shortgrass meadow; associated with Scapania scandica var. scandica, S. curta, Cephalozia bicuspidata, Lophozia ventricosa s.l., $L$ excisa, $L$ wenzelii, L major, Anastrophyllum minutum, Nardia geoscyphus, etc. With gemmae and androecia.

\section{Scapania mucronata Buch}

NT: Khakhayayaha I.

On bare loamy sandy ground in spotty hillock yernik tundra with Cephaloziella arctica, Cephalozia bicuspidata, Odontoschisma macounii, Anthelia juratzkana, Scapania cf. obcordata. With gemmae. This report is based on sparse material. The species is represented by mod. parvifoliacolorata-gemmipara. Nevertheless the plants are quite typical: brownish, without any traces of red or purplish pigment, with undifferentiated marginal leaf cells and rather short keel, $<0.5$ the ventral lobe in length. In spite of intensive gemma formation the leaf margins are entire. 
Scapania praetervisa Meyi.

AT: Belyy I, Khabelyaha I, Tambey I, Kharasavey II; NT: Matyuiyaha I, Tomboitosyo II, Neromayaha II, Lyakkotosyo II; ST: Khutyyaha I, Laptayaha I.

In diverse moss, dwani willow-moss tundras, polygonal dwarf shrub-lichen-Gymnomitrion and dwarf shrub-moss-lichen tundras, high-centered polygon and in grasssedge tundra. Often with gemmae, once with androecia and juvenile perianths.

Scapania irrigua (Nees) Nees var. irrigua $f$. irrigua

AT: Belyy III (Zhukova \& Rebristaya 1987), Khabeiyaha I, Kharaaney I; NT: Matyuiyaha II, Bovanenkovo 1, Tomboltosyo I, Neromayaha I, Saletayaha 1, Khakhayayaha I; ST: Khutyyaha III, Khevesyo III, Laptayaha III, Khadytayahe 1 .

In diverse moist sedge-moss tundras, mosscotton grass and sedge bogs, near banks of water courses and lakes, etc. Gemmae, androecia and perianths rare.

Scapania irrigua var. irrigua f. rubescens (Buch) Schust.

NT: Manty to I.

In sedge bog. With androecia.

Scapania irrigua var. rufescens (Loeske) Loeske

NT: Bovanenkovo 1 .

In cotton grass-sedge-hypnum bog, among Calliergon sarmentosum.

Scapania degenii Schiffn. ex K. Muell. ( $S$. hyperborea auct. non Joerg. p.p. - Potemkin 1989)

NT: Khakhayayaha II.

In willow-sedge lichen-moss and sedgeHylocomium tundras, associated with Ptilidium ciliare, Tritomaria quinquedentata, Blepharostoma, Cephaloziella arctica, Lophozia heterocolpos, Scapania cuspiduligera, and Anastrophyllum minutum.

Yamal plants represent mod. grandifoliaintegrifolia - colorata -egemmipara. Potemkin (1989) attributed them to Scapania hyperborea because of the absence of gemmae, occasionally dorsally arched leaves with entire margins and usually not apiculate lobes of which the dorsal is comparatively large. An analysis of the Yamal specimens of $S$. degenii and the specimen from Arctic Alaska determined by W. C. Steere July 22,
1951, which contains plants without gemmae, with dorsally arched, entire margined leaves as well as rather typical plants with gemmae and dentate leaf margins, showed that leaf teeth formation in the species correlates with gemma formation, resulting in apiculate leaf lobes, of which the ventral often becomes more narrow.

Phenotypes of Scapania degenii without gemmae differ from $S$. hyperborea in the following features: 1) oil-bodies usually persistent in drying; 2) keel distinctly shortly winged (a winged keel is an exception in $S$. hyperborea - I have never seen it in arctic plants of the species, while $K$. Mueller (1951 - 58) mentioned it); 3) semicircular (vs irregular) cell position in leaf lobes; 4) the often 3 -stratose cortex (vs $1-2$ stratose, only exceptionally 3 - stratose) (for evaluation of the last character it is necessary to take into account habitat conditions).

Scapania hyperborea Joerg. (incl. f. subaequalis Schust.; ? S. brevicaulis auct. non Tayl. - Zhukova \& Rebristaya 1986)

AT: Belyy 1, Khabelyaha II, Kharasavey I; NT: Matyuiyaha I, Bovanenkovo I, Tomboitosyo I, Neromayaha I, Mantyto I, Yuribeitoyaha I; ST: Khutyyaha II, Khevesyo I.

In sedge bogs and tundras (often of nival type), herb nival communities, in moss (Hylocomium, Dicranum) and moss-lichen tundras, on sandy margin of lake; often on sandy ground. Sporadically with gemmae, which vary in coloration from pink, purple and violet to fuscous, reddish fuscous and purple blackish fuscous; once with androecia. For characteristics of reproduction of the species by gemmae and for consideration of status of f. subaequalis see Potemkin (1993b).

Scapania hyperborea is an extremely malleable species represented in the Arctic by numerous phenotypes which in details were described by Schuster (1974) and Schuster and Damsholt (1974). Most paradoxical of them is the Scapania helvetica-phenotype. The plants reported from Yamal as S. brevicaulis Tayl. (Zhukova \& Rebristaya 1986) apparently should be attributed to this phenotype. They are very small, brownish pigmented with bistratose 
keel at least in basal half of leaves and very characteristic for the species broadly oval to almost spheric pinkish to purple 2 - celled gemmae.

Scapania tundrae (H. Arn.) Buch ( $S$. pulcherrima Schust. syn. nov.)

AT: Belyy I, Kharasavey I; NT: Matyuiyaha II, Bovanenkovo 1, Tomboitosyo I, Neromayaha III, Manty to II, Saletayaha I, Khakhayayaha II; ST: Khutyyaha IV, Khevesyo II.

In sedge, sedge-moss and moss-cotton grass bogs, late snow areas, hummock dwarf shrub sedge-lichen-moss and tussock dwarf shrub Dicranum tundras, on sandy margin of lake, at the foot of Sphagnum tussocks on margin of lake, usually on sandy soil, often with Scapania hyperborea. Sporadically with gemmae. For information about leaf modifications that result from gemma formation see Potemkin (1993b).

After investigation of Yamal collections of Scapania tundrae, including some $S$. pulcherrima-like phenotypes (mainly from Khutyyaha, sedge-Sphagnum tussock bog, July 30, 1977, E. N. Andrejeva, N 49) and numerous transitional forms to $S$. tundrae phenotypes, I think that $S$. pulcherrima, described from West Greenland (Schuster 1974), represents a form of $S$. tundrae, developing in peculiar ecological conditions.

While Schuster (1974) considers that Scapania pulcherrima "exhibits the same relationships to $S$. degenii as does $S$. tundrae to the $S$. irrigua-hyperborea complex", I can not agree with this statement. $S$. pulcherrima differs from $S$. degenii in its not persistent and smaller oil-bodies; pigmentation and broadly oval shape of its $\mathbf{2}$ - celled gemmae; presence of coarse, irregular broad-based teeth; ecological behaviour; etc. On the other hand, all distinctive features of $S$. pulcherrima or tendencies for their manifestation occur in diverse phenotypes of $S$. tundrae. $S$. pulcherrima shares with $S$. tundrae cell size, oil-body and gemma characteristics, and ecological behaviour. Such features as short, winged and semicirculary curved keel, minutely papilloseverruculose cuticle and vinaceous pigmentation of ventral leaf bases occur more or less often also in Siberian plants of $S$. tundrae (cf. Mueller 1951 - 58, Fig. 347: a, b). Schuster (l.c.) characterizes the leaves of $S$. tundrae as entire-margined or bearing scattered small teeth associated with gemma formation. However, the tendency to develop the crooked margin with solitary obscure broad-based teeth or marginal projections not associated with gemma formation is clear from his Fig. 407. This feature is rather common for Siberian plants of the species and gives them a rather peculiar appearance. It is not difficult to imagine the transformation of such marginal projections into irregular broad-based teeth of $S$. pulcherrima.

Scapania paludicola Loeske \& K. Muell. var. rotundiloba Schust. ( $S$. paludicola var. paludicola auct. non Loeske \& K. Muell. Gribova \& Potemkin 1988)

AT: Belyy I, Tambey I, Kharasavey II; NT: Matyuiyaha II, Bovanenkovo 1, Tomboltosyo II, Neromayaha III, Mantyto I, Marre Sale 3, Khakhayayaha II, Lyakkotosyo I; ST: Khutyyaha II, Khevesyo IV, Laptayaha I, Kharangyneto 2, Er'yaha II, Khadytayaha 1 .

In sedge, Sphagnum, sedge-Sphagnum and moss-cotton grass bogs, in moist dwarf shrub-sedge-moss, grass-sedge, cotton grass and dwarf shrub-Sphagnum-cotton grass tundras, near water courses and lakes, etc. Rarely with androecia and gemmae, once with perianth. Modifications of gemmiparous leaves are like those in $S$. hyperborea (Potemkin 1993b).

Variety rotundiloba is characterized by obtuse to rotund edentate leaf lobes and reddish gemmae. Vinaceous red pigmentation of ventral leaf bases is usually absent in Yamal plants. Only a few collections of the variety were investigated in a fresh state, and oil-bodies were usually (5)6-8(10) per cell and 3-7 mkm in diam. The level of genetic separation of var. rotundiloba from the type variety is not clear and its taxonomic status needs investigation.

Scapania cf. kaurinii Ryan.

ST: Khevesyo I.

At the foot of peat outcrop in flat-centered polygon with Calycularia laxa, Scapania scandica, and Marchantia polymorpha. 
This report is based on sparse sterile material. The plants are mod. parvifoliacolorata of the species. They are assigned to Scapania kaurinii on the following criteria: 1) leaf lobes subequal, characteristically dorsally arched and adaxially concave in better developed plants; 2) keel distinct, stiff, 2(3) - stratose throughout; 3) cortex 1 - 2 stratose, distinctly differentiated, of very thick-walled cells; 4) trigones moderate, straight-sided to faintly bulging. These characters separate the plants under consideration from all small phases of the extremely variable $S$. hyperborea and from other species of section Irrigua (K. Muell.) Buch that sometimes resemble $S$. kaurinii.

Scapania uliginosa (Lindenb.) Dum. s. str.

AT: Belyy I; NT: Neromayaha I; ST: Khutyyaha I, Khevesyo I.

In grass-sedge, sedge-moss and cotton grass sedge bogs usually with flowing water, among species of Drepanocladus, Calliergon, Sphagnum, Meesia, Paludella squarrosa, Aulacomnium turgidum and associated with Chiloscyphus fragilis, Gymnocolea inflata, $G$. fascinifera, Cladopodiella fluitans, Scapania hyperborea, etc. Once with androecia.

Yamal plants are not quite typical. Leaf cells often develop prominent trigones and a punctate-papillose to striolate cuticle at the leaf base. Purple pigmentation occurs usually only near the ventral leaf base.

\section{Scapania subalpina (Nees ex Lindenb.) Dum.}

AT: Belyy I (Zhukova \& Rebristaya 1987).

In pool of sedge-moss bog.

\section{Scapania crassiretis Bryhn}

AT: Kharasavey I; NT: Lyakkotosyo I; ST: Khevesyo III.

In moist grass-sedge-dwarf shrub-moss, dwarf shrub-lichen-moss, grass-cotton grass and grass spotty tundras, more often on moist bare ground, associated with Tritomaria quinquedentata, Anastrophyllum minutum, Barbilophozia kunzeana, B. binsteadii, Ptilidium ciliare, Cephalozia bicuspidata, Scapania paludicola var. rotundiloba, S. scandica, Odontoschisma ma- counii, Lophozia ventricosa s.l., etc. Often with gemmae. On bare soil Scapania crassiretis often develops mod. densifoliacolorata with leaves often rather briefly decurrent ventrally. These plants can be confused with $S$. degenii. A principal difference of these species is different keelstem angles in the same insolation conditions: in forms of $S$. crassiretis from exposed sites the keel-stem angle in the distal part of the keel does not exceed $110^{\circ}$, but in $S$. degenii it is up to $160-185^{\circ}$; in shade they are $80-90^{\circ}$ and $100-120^{\circ}$ respectively (cf. Schuster 1974). Moreover the keel of $S$. crassiretis is usually almost straight in distal part vs more or less arched in $S$. degenii; marginal teeth of $\mathrm{S}$. crassiretis are mostly uniseriate with a strongly elongated apical cell (excepting the mod. subintegrifolia-egemmipara which has weakly developed, solitary, 1 - celled, slightly elondated teeth) vs with slightly elongated apical cell, often with two cells at base; cells with coarse nodulose trigones in $S$. crassiretis vs moderate, more or less bulging trigones in S. degenii.

Scapania simmonsii Bryhn \& Kaal.

NT: Yuribeitoyaha II.

On bare ground in herb-dwarf shrub moss tundra, on hummock in sedge-willow-moss hummock tundra, in moist depression in hummock-pool sedge-yernik-willow tundra, associated with Ptilidium ciliare, Blepharostoma, Odontoschisma macounii, Anastrophyllum minutum, Barbilophozia quadriloba f. glareosa, and Tritomaria quinquedentata.

Together with typical plants some weakly developed shoots were found. They represent mod. laxifolia-parvifolia-integrifolia-subcolorata and mod. parvifolia-angustifolia-integrifolia-colorata. Plants of the last modification are only $0.6 \mathrm{~mm}$ wide and $2 \mathrm{~mm}$ long and resemble very much the species of the sectio Curtae (K. Muell) Buch. They have plane leaves; cells with moderate, only sporadically nodulose trigones; a comparatively weakly papillose cuticle; and stem with a distinctly differentiated, 1(2) - stratose, blackish cortex of thick-walled cells. 


\section{Diplophylum (Dum.) Dum.}

Diplophyllum taxifolium (Wahlenb.) Dum. var. macrosticta Buch

AT: Belyy V, Kharasavey II; NT: Mantylo II; ST: Khutyyaha I, Laptayaha III.

Predominantly in late snow areas mostly on sandy, exceptionally on loamy, ground, sporadic in some moss, moss-lichen, herb, sedge and cotton grass tundras. According to Zhukova \& Rebristaya (1987) in Belyy the species occurs in communities on sandy, loamy and peaty ground. Gemmae rare.

The distribution of the species in Yamal is not uniform: in many localities it is absent or rare, but in Belyy it is common species with rather wide ecological amplitude.

\section{GEOCALYCACEAE Klinggr.}

Subfam. LOPHOCOLEOIDEAE Rodway

\section{ChILOSCYPhus Corda}

Subgen. LOPHOCOLEA (Dum.) ?Engel \& Schust.

\section{Chiloscyphus minor (Nees) Engel \&} Schust. (Lophocolea minor Nees)

NT: Neromayaha 1; ST: Khytyyaha I.

In Sphagnum-sedge, herb-moss and lichen willow stands on humus, associated with Scapania curta, Cephalozia bicuspidata, $C$. pleniceps, Blepharostoma, etc. With gemmae.

Plants from Neromayaha (lichen willow stand) are very small to medium in size, from $130 \mathrm{mkm}$ to $1000-1.500 \mathrm{mkm}$ wide. The smallest phases have an almost transverse leaf orientation on the stem. Gemmae occur in small quantity only on occasional plants. They become free 2 - celled, more rarely in 3 - or 4 - celled more or less globose bodies.

\section{Subgen. CHILOSCYPHUS}

Although Chiloscyphus pallescens (Ehrh. ex Hoffm.) Dum. was reported previously for the peninsula (Andrejeva 1981; Zhukova \& Rebristaya 1986,1987; Gribova \& Potemkin 1988) I I have found no typical plants of this species in investigated specimens. I consider all earlier reports doubtful also because of the chromosome investigation of arctic Chiloscypus (Steere \& Inoue 1978), that showed that large-celled $\mathrm{Ch}$. pallescens-like arctic phenotypes have 9, not 18 chromosomes and should be attributed to $C h$. polyanthos rather than to $\mathrm{Ch}$ pallescens.

For differentiation of Chiloscyphus pallescens s.l. and Ch polyanthos s.l. oil-body characteristics may be useful. According to Schuster (1980) oil-bodies of $\mathrm{Ch}$. polyanthos are (1)2, more rarely $3-4(5)$ per cell, large: $4-5 \times 7-12 \mathrm{mkm}$ to $6-7 \times 8$ 12(18) $\mathrm{mkm}$ vs in $\mathrm{Ch}$ pallescens mostly 3) $4-6(10-12)$ to $8-12$ per cell, smaller: spherical $4-5.5 \mathrm{mkm}$, oval $4-4.5(5) \times 8$ $9(10-11) \mathrm{mkm}$.

Unfortunately all Yamal specimens of Chiloscyphus were studied without oil-bodies. I retain $\mathrm{Ch}$. fragilis as a species because most Yamal specimens very good fit to it and consequently almost no doubts were arisen during the investigastion of the Yamal materials. Nevertheless the status of this species should be revised in the future on the basis of not only morphological but biochemical and chromosome characters.

Chiloscyphus fragilis (A.Roth) Schiffn. (Ch. pallescens auct. non (Ehrh. ex Hoffm.) Dum. - Andrejeva 1981; Zhukova \& Rebristaya 1986,1987; Gribova \& Potemkin 1988)

AT: Belyy I, Khabeiyaha II, Tambey I, Tiryyaha 1 , Kharasavey II; NT: Matyuiyaha I, Bovanenkovo I, Tomboitosyo II, Neromayaha III, Marre Sale 11 , Yuribeitoyaha II, Khakhayayaha II; ST: Khutyyaha I, Khevesyo II, Er'yaha I.

Usually in sedge and cotton grass bogs, moist sedge and cotton grass tundras, moss willow stands, etc. Once with mature capsules.

PLAGIOCHILACEAE (Joerg.) K. Muell.

Plagiochila (Dum.) Dum.

Plagiochila asplenioides (L.) Dum. subsp. porelloides (Torrey ex Nees) Schust. (incl. f. subarctica (Joerg.) Schust.; P. arctica auct. non Bryhn \& Kaal. - Andrejeva 1981)

NT: Bovanenkovo 2; ST: Khutyyaha II.

In Equisetum-moss, moss and flood plain willow stands, hummock moss-dwarf shrub tundra, sedge bog; associated with Drepanocladus uncinatus, Mesoptychia, Lophozia gillmanii, Aneura pinguis, Pellia neesiana, etc.

\section{ARNELLIACEAE Nakai}

ARNELLIA Lindb. 
Amellia fennica (Gott.) Lindb.

NT: Matyuiyaha I, Yuribeitoyaha III; ST: Khevesyo I, Laptayaha III, Kharangyneto 1 .

In diverse spotty tundras, herb-E'quisetum willow stands, old fire place, late snow area; on bare and thinly turfed soil, associated with Barbilophozia quadriloba, Lophozia heterocolpos, L. grandiretis, Tritomaria scitula, T. heterophylla, T. quinquedentata, Scapania gymnostomophila, Jungermannia polaris, Odontoschisma macounii, Cryptocolea, Blepharostoma, Nardia geoscyphus, etc. The species varies from mod. densifoliacolorata to mod. laxifolia-viridis.

CALYPOGEIACEAE (K, Muell.) H. Arn.

\section{CAlyPOGEIn Raddi}

Calypogeia sphagnicola (H.Arn \& J.Perss.) Warnst. \& Loeske

ST: Laptayaha I.

In tussock swampy Dicranum-Sphagnum tundra on tussock among Sphagnum with Barbilophozia binsteadii.

Calypogeia muelleriana (Schiffn.) K.Muell.

NT: Lyakkotosyo I; ST: Khevesyo I, Laptayaha I, Er'yaha II.

In cotton grass and Ledum tundras, highcentered polygon, moss-cotton grass bog, associated mostly with Barbilophozia binsteadii, Anastrophyllum minutum, Lophozia ventricosa var. longiflora, Cepiralozia bicuspidata. Once (Er'yaha) with gemmae.

\section{CEPHALOZIACEAE Migula}

SUbfam. CEPHALOZIOIDEAE

\section{Pleurocladula Grolle}

Pleurocladula albescens (Hook.) Grolle. s.l.

AT: Belyy III, Khabelyaha II, Tambey I, Kharasavey I; NT: Matyuiyaha II, Tiutey 4, Manty to III, Khakhayayaha III; ST: Khutyyaha III, Khevesyo IV, Laptayaha II, Er'yaha II, Khadytayaha 1 .

Usually in late snow areas, rarely on spots in spotty tundras. Once (Tiutey) with gemmae (see Potemkin 1993b).

Cephalozia (Dum.) Dum.

Cephalozia bicuspidata (L.) Dum. subsp. ambigua (C. Mass.) Schust.

AT: Belyy II (Zhukova \& Rebristaya 1987), Khabeiyaha I, Tambey I, Kharasavey I; NT: Tiutey I, Tomboitosyo I; ST: Khevesyo II, Laptayaha I, Er'yaha I.
In late snow areas and on spots in spotty tundras. Sporadically with perianths, twice with gemmae.

The overlapping of the variability ranges of Cephalozia bicuspidata subsp. ambigua and subsp. bicuspidata is considerable. Most difficult and sometimes impossible to separate is mod. parvifolia of the both subspecies. All doubtful phenotypes of $C$. bicuspidata s.l. were attributed to subsp. bicuspidata. Schuster's (1988:180) arguments for distinguishing this taxon as a subspecies rather than a species seem well founded.

\section{Cephalozia bicuspidata subsp. bicuspidata}

AT: Belyy III, Khabelyaha $V_{*}$ Tambey $V$, Kharasavey III; NT: Matyulyaha III, Tiutey 2, Bovanenkovo 3, Tomboitosyo III, Neromayaha V, Manty to III, Saletayaha 5, Yuribeitoyaha I, Khakhayayah\& V, Lyakkotosyo II; ST: Khutyyaha V, Khevesyo V, Laptayaha III, Kharangyneto 4, Er'yaha III, Khadytayaha 4.

In diverse moss, lichen, and spotty tundras, late snow areas, herb formations on sand, sedge-moss bogs, etc. Perianths and mature capsules rather frequent, gemmae rare.

\section{Cephalozia leucantha Spruce}

NT: Neromayaha 1.

On humus-rich soil among crustose lichens with Anastrophyllum minutum, Lophozia sp., in willow stand on loamy soil.

\section{Cephalozia pleniceps (Aust.) Lindb.}

AT: Belyy I, Khabelyaha III, Tambey III, Kharasavey I; NT: Matyulyaha 1, Bovanenkovo 2, Tomboitosyo I, Neromayaha III, Manty to II, Saletayaha 3, Yuribeitoyaha II, Khakhayayaha III, Lyakkotosyo I; ST: Khutyyaha III, Khevesyo V, Laptayaha III, Er'yaha III.

On steep herb and nival slopes, in spotty, mostly lichen-moss and sedge-moss, and dwarf shrub sedge-(grass)-moss tundras, on peat outcrops, edges of lakes and water courses, in sedge-moss and moss bogs. Often with perianths and mature capsules.

The species is very malleable. On exposed bare soil it is represented by small, $1.5-4$ $\mathrm{mm}$ long, very fleshy whitish phenotypes with dense leaves and lobes terminated by one obtuse not elongated cell. Perianths are 4-5 - stratose at the base and unistratose only in upper half, occasionally only near the mouth. In wet moss tufts comparatively large, up to $27 \mathrm{~mm}$ long, phases of the species occur. They are greenish, not fleshy, with 
distant leaves with apiculate lobes of $1-2$ cells.

Cephalozia lunulifolia (Dum, Dum.? $C$. affinis auct. non Steph. - Zhukova \& Rebristaya 1987 (the species was identified in sterile state that is actually imposible (cf. Schuster 1974)),

AT: Belyy I (Zhukova \& Rebristaya 1987), Khrasavey I; NT: Tomboitosyo Is Neromayaha i; ST: Khutyyahe III, Khevesyo III, Khadyta yaha $l$.

In moist tussock moss tundras, Sphagnum yerniks, peat outcrops, moss-lichen and herb-moss tundras, sedge bog and willow lichen nival tundra. Once (Xhutyyaha) with gemmae. Gemma formation leads to development of reduced and multilobed leaves as well as large underleaves (Potemkin 1993b).

The species is usually represented by forms with distant, longly decurrent leaves. Most vigorous plants may be to $40 \mathrm{~mm}$ long and 1 $\mathrm{mm}$ wide. In Kharasavey mod. densifolia was found. The plants resemble Cephalozia pleniceps. They have subtransverse oriented shortly decurrent leaves with not connivent lobes terminated usually by 1 cell. They differ from $C$. pleniceps in the following distinctive features: 1) antical leaf margin decurrent in parallel to stem vs subtransverse in C. pleniceps; 2) rhizoids often copiously branched near the ends vs nonbranched, dilated near the ends; 3) basal cell of uniseriate lobe apiculus comparatively narrow, ca. 28 - 35 mkis wide at the base vs usually more than $33 \mathrm{mkm}$ wide; 4) dorsal cortical cells more than 3 times wider than medullary cell diameter vs less than 3 times wider in C. pleniceps; 5) ventral, stolon-like branches heliotropic vs geotropic; 6) all plants sterile that is a characteristic feature of the dioicous $C$. lunulifolia, not of the autoicous $C$. pleniceps.

Some phases of Cephalozia lunulifolia resemble the amphiatlantic species $C$. macrostachya Kaal. They may develop comparatively small cells in lobe bases; leaves to $17-19$ cells broad with nonconnivent lobes; and similar stem anatomy. They differ in the almost entire perianth mouth and bract margins as well as in thin-walled cells which are, at least partly, more than $25 \mathrm{mkm}$ wide in lobe bases.

Cephalozia connivens (Dicks.) Lindb.

NT: Neromayaha 1.

In nival willow stand on bare slightly humusy loamy sandy soil among Cephalozia bicuspidata and C. pleniceps. Northernmost report of the species.

Investigated plants differ distinctly from acmixed Cephalozia pleniceps in leaf insertion; cell size (dorsal cortical cells 40 $70 \times 50-85 \mathrm{mkm}$ vs $30(50) \mathrm{mkm}$ wide; cells of leaf lobe base $40-50 \times 40-56 \mathrm{mkm}$ vs 30 , rarely $35-40 \mathrm{mkm}$ in diam.); leaves only $9-14$ cells wide with dorsal lobe $3-5$ cells wide and ventral (3) $4-5(6)$ cells wide vs (14) $16-23$ cells wide with wider lobes respectively; absence vs presence of stolons; stem of $12-13$ rows of cortical cells (5 dorsal rows and 7-8 lateral and ventral rows) and $16-17$ rows of medullary cells vs 24 rows of cortical and 32 rows of medullary cells, etc. The main difference from plants of the temperate region is thin-walled medullary cells. Comparative study of temperate and arctic species of Cephalozia as well as of Jungermannia subgen. Plectocolea showed, however, that development of thick-walled medullary cells is characteristic only for temperate populations and is considerably rarer and more weakly expressed in the Arctic.

Subfam. ODONTOSCHISMatoIdEAE Buch ex Grolle

Cladopodielua Buch

Cladopodiella fluitans (Nees) Buch ST: Khutyyaha II.

In bogs with flowing water among Drepanocladus exannulatus, $D$. fluitans $\mathrm{f}$. pseudostramineum, Calliergon sarmentosum, with Scapania uliginosa, S. hyperborea, Gymnocolea fascinifera and among Sphagnum with Gymnocolea fascinifera and $G$. inflata var. acutiloba; in high-centered polygon among Gymnocolea inflata var. acutiloba.

The plants collected in bogs with flowing water are quite typical but in the polygon they are represented by mod. parvifoliafusca. They have a stem only 5 cells high, 
with distict underleaves and cortical cells $28-32 \mathrm{mkm}$ wide and median leaf cells ca. 28 × $30-38 \mathrm{mkm}$.

\section{Cladopodiella francisci (Hook) Buch ex Joerg.}

ST: Khutyyaha I, Khady tayaha 3

In tussock tundras, on upland in bog and on the margin of loamy landslip, associated with Lophozia cf. savicziae, Gymnocoleu inflata, Cephalozia bicuspidata, Gymnomitrion corallioides, Scapania scandica, and Marsupella sprucei. Offen with gemmae, perianths and mature capsules. Gemmae more or less angulate, $1-2$-celled, colourless to violetish, $23-25(39) \mathrm{mkm}$. Spores from $11-13$ to $15-16 \mathrm{mkm}$ in diam. Elaters $9-13 \mathrm{mkm}$ in diam., with 2 brown spirals $2.5 \mathrm{mkm}$ wide. Two capsules found in collection from Khutyyaha, margin of loamy landslip, are not typical: valves coherent in apical part of capsule; epidermal layer with nodular thickenings on alterating longitudinal walls; and inner layer with mostly complete semiannular bands.

\section{Odontoschisma (Dum.) Dum.}

Odontoschisma elongatum (Lindb.) Evans

NT: Matyuiyaha II, Mantyto II, Sebayaha $I$, Khakhayayaha II; ST: Er'yaha I.

In diverse bogs, dwarf shrub sedge-lichenmoss and dwarf shrub-lichen tundras, on steep slope, associated usually with Ptilidium ciliare, Blepharostoma, Cephalozia bicuspidata, Gymnocolea inflata, Barbilophozia binsteadii, B. kunzeana, Lophozia ventricosa var. longiflora and Scapania irrigua, but on steep slope also with Anthelia juratzkana, Pleurocladula albescens, Calycularia laxa and Anastrophyllum sphenoloboides.

The species varies from mod. densifolia colorata to mod. laxifolia-colorata vel subcolorata, mod. viridis occurs very rarely.

Odontoschisma macounii (Aust.) Und.

AT: Belyy III, Khabeiyaha I, Kharasavey I; NT: Marre Sale 1, Yuribeitoyaha II, Khakhayayaha I, Lyakkotosyo I; ST: Khevesyo III, Laptayaha II, Er'yaha I, Kharangyneto I.

On bare and thinly turfed soil in diverse tundras, in flat centered polygons, moist horse-tail nival and sedge willow stands, apparently only in sites with comparatively rich soils.

\section{CEPHALOZIELLACEAE DOUin}

\section{CePHalozalelia (Spruce) Schiffn.}

Cephaloziella subcentata Warnst.

NT: Bovanenkovo 1 , Tomboitosyo $I$, Neromayaha I, Yuribeitoyaha I; ST: Khutyyaha II, Er'yaha I, Khadytayaha 1 .

in willow-yernik sedge and sedge-Dryaslichen tundras, sedge-moss and polygonal bogs, associated with Sphagnum, Dicranum elongatum, Meesia, Blepharostoma, Cephaloziella rubella subsp. arctogena, Anelira cf. pinguis, etc. Often with perianths, once with mature capsules and genmae.

This species is often confused in the Arctic with Cephaloziella rubella subsp. arctogena. It differs from this taxon in sex distribution (auticous vs paroicous), ability of hygric forms to produce spinose teeth at leaf base as in C. elachista (Jack ex Gott. \& Rabenh.) Schiffn., and in perianth mouth, bract, and capsule wall characters (see Potemkin 1992a).

Cephaloziella divaricata (Sm.) Schiffn. var. divaricata

AT: Khabeiyaha I, Tumbey I, Kharasavey I; NT: Matyuiyaha I, Tiutey 1, Bovanenkovo 1, Tomboitosyo II, Neromayaha II, Mantyio I, Marre Sale 1, Yuribeitoyaha II, Khakhayayaha I, Lyakkotosyo I; ST: Khutyyaha II, Khevesyo II, Laptayaha II, Kharangyneto 3, Er'yaha I.

In diverse moss, sedge, sedge-moss, dwarf shrub and sedge-iichen tundras, cotton grass-sedge-Sphagnism bog, on peat outcrop, on bare loamy ground on edge of temporary water course. Often with gemmae, rare with perianths.

Cephaloziella divaricata var. scabra (M. A. Howe) S. Arn.

NT: Tomboilosyo I, Lyaikkotosyo 1; ST: Khevesyo I.

In sedge-moss and moss-herb willow stands, hummock sedge-yernik moss tundra, associated with Lophozia jurensis, $L$. ventricosa, Ptilidium ciliare, Anostrophyllum minutum, etc. Once with gemmae.

Cephaloziella divaricata var. polystratosa (Schust. \& Damsh.) Potemk. comb. nov. (Cephaloziella byssacea (A. Roth) Warnst. var. polystratosa Schust. \& Damsh., 


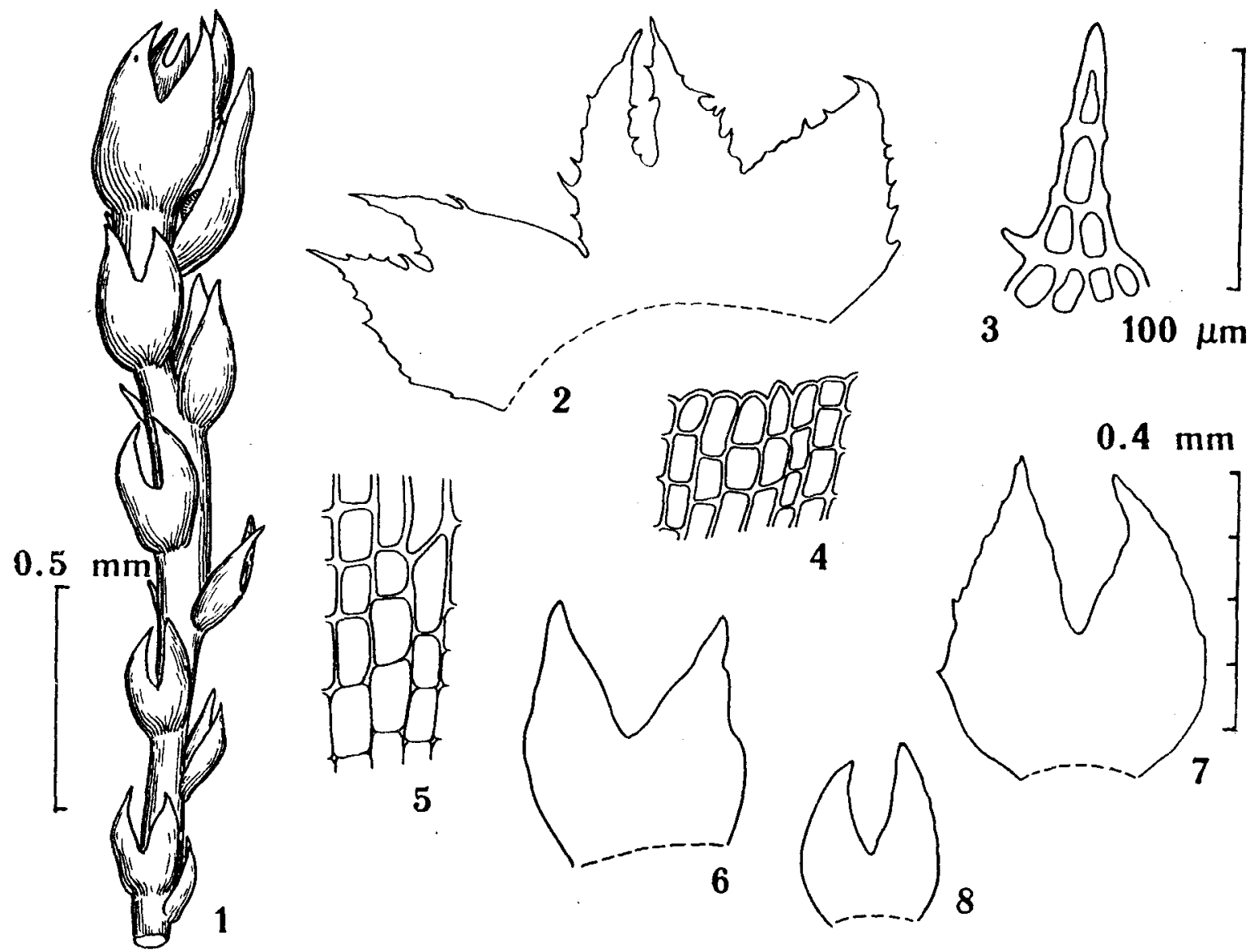

Fig. 7. Cephaloziella rubella subsp. arctogena. (1) Young fertile shoot (x56). (2) Female bracts and bracteole (x80). (3) Apex of female bract $(\times 300)$. (4) Sector of perianth mouth $(\times 300)$. (5) Median and basal cells of female bract (x300). (6,7) Male bracts (x80). (8) Leaf (x80). Scale bars: $0.5 \mathrm{~mm}$ - for 1; $0.4 \mathrm{~mm}-$ for $2,6-8 ; 100 \mathrm{mkm}-$ for 3 5. All from Khutyyaha (After Potemkin 1992a).

Phytologia, 63(5):327, 1987)

NT: Neromayaha I, Saletayaha 1.

On thinly turfed loamy sandy soil, associated with Encalypta sp. With gemmae. First report for Eurasian Arctic. Previously the variety was known from South Greenland and, in Eurasia, from Leningrad (St. Petersburg) Province (for detailed descriptions and illustratuions see Schuster 1988, Potemkin \& Tcherepanov 1993).

Cephaloziella rubella (Nees) Warnst. subsp. rubella

NT: Bovanenkovo 1, Marre Sale 1.

In grass-sedge moss and moss-dwarf shrub tundra. With perianths.

Cephaloziella rubella subsp. arctogena (Schust.) Schust. \& Damsh. (C. rubella auct. non (Nees) Warnst. p.p. - Gribova \& Potemkin 1988; C. subdentata auct. non Warnst. p.p. - Zhukova \& Rebristaya 1986, 1987; Gribova \& Potemkin 1988) (Fig. 7)

AT: Belyy I; NT: Matyuiyaha I, Bovanenkovo I, Tomboitosyo II, Neromayaha III, Mantyto I, Saletayaha 1, Yuribeitoyaha II, Khakhayayaha II, Lyakkotosyo III; ST: Khutyyaha III, Khevesyo I, Kharangyneto 1 , Khadytayaha 4 .

In dwarf shrub-moss and sedge-moss tundras, swampy sedge-(cotton grass)-moss and dwarf shrub-moss (often Sphagnum) communities. Often with perianths, sporadically with mature capsules. For differentiation see Potemkin 1992a).

Cephaloziella rubella cf. var. elegans (Heeg.) Schust.

NT: Tomboitosyo I, Marre Sale 1; ST: Khutyyaha I. 
In herb willow stands, spotty polygonal and grass-sedge moss tundras, associated with Cephaloziella rubella subsp. rubella and subsp, arctogena, Scapania scandica, Lo phozia alboviridis, Cephalozia bicuspidata, $C$. pleniceps, and Anastrophyllum minutum. The only one perianth have been seen. All Yamal collections of this variety are poor. The occurrence of Yamal plants together with the other taxa of $c$. rubella leads to certain doubts on their taxonomic isolation (cf. Arnell 1956: 72).

\section{Cephaloziella hampeana (Nees) Schiffn. var. hampeana}

AT: Belyy I; NT: Matyuiyaha I, Bovanenkovo $\ell$, Tomboltosyo II, Neromayaha II, Mantyto i, Khakhayayaha I; ST: Khevesyo II, Laptayaha II, Khadytayaha 1 .

In diverse moist sedge- and grass-moss tundras, sedge and sedge-cotton grass bogs, dwarf shrub-sedge-cotton grass and grasscotton grass tundras, sadge willow stands. Sporadically with perianths and gemmae, once (Khevesyo) with mature capsules.

Cephaloziella hampeana var. sibirica C. Jens.

AT: Belyy (Arnell 1918).

Cephaloziella arctica Bryhn \& Douin (C. rubella auct. non (Nees) Warnst. p.p. Zhukova \& Rebristaya 1986; Potemkin 1989)

AT: Belyy V, Khabelyaha V, Tambey V, Kharasavey III; NT: Matyuiyaha II, Tiutey 2, Bovanenkovo I, Tomboitosyo 1, Neromayaha III, Yuribeitoyaha 1, Khakhayayaha II, Lyakkotosyo II; ST: Khutyyaha II, Khevesyo III, Laptayaha II, Er'yaha I, Khadytayaha 1.

In spotty, predominantly dwarf shrubsedge-(lichen)-moss, and swampy sedgemoss tundras, at the foot of nival slopes, in plant communities on weakly stabilized sand. Sporadically with gemmae, perianths and mature capsules.

In Arctic tundras, growing on bare soil, the species usually develops mod. parvifoliacolorata with purplish fuscous to purplish black pigmentation; comparatively narrow leaves, a little wider than the stem; and reduced amphigastria, which are only sporadically present near shoot apexes. In moist moss tufts mod. viridis and mod. subcolorata usually occur and often resemble Cephaloziella hampeana. They differ from the last species by the presence at least smail underleaves, thick-wailed cells of stem and often of leaves, slightly elongated cells of perianth mouth, female bract characters, etc.

Cephaloziella grimsulana (Jack ex Gott. \& Rabenh.) Lacout.

NT: Neromayahs $\mathrm{II}$, Salewyaha 2.

On bare clay and humus clay soil on landslip slopes, on loamy sand on steep slope, associated with Rarbilophozia hyperborea, Lophozia excisa, etc. With gemmae, once with juvenile perianth.

Cephalozielia uncinata Schust. (C. siriatula (C.Jens.) Douin var, argudentata S. Arn. syn. nov.; $C$. subdentata auct. non Warnst. p.p. Andrejeva 1981; Zhukova \& Rebristaya 1986, 1987)

AT 1; NT: Matyulyaha II, Tutey $l$, Bovanenkovo $I$, Tomboitosyo I, Neronayaha IV, Manty to I, Marre Sale 1, Yuribeitoyaha II, Khakhayeyaha II, Lyakkotosyo II; ST: Khutyyaha II, Laptayahu I. Er'y\&ha $X$.

In diverse swampy communities of sedge, cotton grass and mosses (often Sphagnum), Sphagnum yerniks, dwarf shrub-(cotton grass)-moss and herb-dwarf shrub-moss tundras, on margin of lake. Almost always with perianths, sporadically with mature capsules.

The main peculiarity of Yamal plants is a smooth or slightly papillose cuticle characteristic not only for xeromorphic phenotypes (Schuster 1980) but for mesic and hygric forms also. This feature, however, is very malleable in the species. Investigation of Greenland material showed that the character of the cuticle often varies considerably from leaf to leaf on the same shoot and from plant to plant in the same specimen as in RMS 66-054, 66-306a, $66-1285 \mathrm{a}, \quad 70-2128$, eic., and, consequently, it is impossible to explain such variability only by factor of moisture. The other features of the species are quite typtcal. Robust forms of the species may develop solitary teeth, however, not only at leaf base but on sinus sides also.

Investigation of the description, illustrations and specimens of Cephaloziella striatula var. argudentata from Novaya Zemlya (Arnell 1947), which was assigned later by the author (Arnell 1956) as a synonym of $C$. subdentata var. spinigera H. Arn. \& C. Jens., 
showed that it is almost identical with Yamal plants of $C_{\text {: }}$ uncinata. It shares with this species such important features as uncinate leaf apexes of $1-5$ superimposed cells with strongly elongated terminal one, coarsely dentate female bracts with uncinate apexes of strongly elongated cells and a ciliate-dentate perianth mouth of strongly elongated cells, which are free on most of their length. The only differences, excepting a faintly papillose cuticle, are sporadically more narrow leaf lobes, only 4-7 cells broad at ba-, and longer uniseriate lobe apexes, to 5 cells long.

\section{PTILIDIACEAE Klinggr.}

\section{Priumium Nees}

Ptilidium ciliare (Los) Hampe

AT V; NT V; ST V.

One of the most widespread Yamal hepatics in diverse plant communities, excepting bogs and dry lichen tundras on sand. Sporadically it is a dominant species, forming large mats about several hundred square metres.

Ptilidium ciliare is an extremely malleable species. In Yamal it is mostly represented by mod. densifolia of diverse coloration: from green and yellowish green to brown, reddish brown, deep purple and blackish violet. The brown pigmented plants occur most often, however. The number of marginal cilia varies greatly also. There are often rather few cilia in plants, growing on bare exposed soil (mod. parvifolia - densifoíia - colorata -oligociliata). Sporadically forms with 25 - 40 cilia in the ventral leaf margin occur. Their cilia are composed of strongly elongated cells, $40-60 \times 11-14(20) \mathrm{mkm}$, and they are sometimes longer than the width of ventral lobe. Celis of these plants are usually larger, than mentioned for the species, to 38 .. $48(56) \times(28) 33-39 \mathrm{mkm}$ at lobe base. These differences are not very constant, however, and such forms often grade into typical ones.

ORDER MARCHANTIALES Limpr. MARCHANTIACEAE (Bisch.) Lindley

MARChantu $L$.

Marchantia alpestris (Nees) Burgeff.

NT: Bovanenkovo 1, Saletayaha $l$.

On old fire place and on edge of water course. With gemma receptacles, archegoniophores and antheridiophores.

Marchantia polymorpha L.

NT: Matyulyaha I, Yuribeitoyaha II; ST: Khutyyahs III, Knevesyo III, Er'yaha III.

On edges of water courses, in karst funnels, cotton grass bogs, at the foot of peat outcrops, near and on fire places. Almost always with gemma receptacles, archegoniophores and antheridiophores.

Marchantia aquatica (Nees) Burgeff.

AT: Kharasavey I.

On margin of lake. With solitary gemma receptacles.

Preissia Corda

Preissia quadrata (Scop.) Nees subsp. hyperborea Schust.

AT: Kharasavey I; NT: Neromayaha I, Lyakkotosyo I; ST: Khutyyahz III, Khevesyo I, Er'yaha 1.

In crevices and on vertical surfaces of steep sandy slopes, on river bank. Sporadically with archegoniophores, antheridiophores and mature capsules. Previously it was known only from North America and Greenland (Schuster 1992b).

The main distinctive features of this taxon from the type subspecies, according Schuster (l.c.), are: plants normally autoecious (vs dioecious); subarctic-arctic (vs predominantly temperate-boreal); male receptacles with a wide, thin, chartaceous, nitid flange, usually arched upward (vs without such flange, the margins not conspiciously curved upward); carpocephalum with 2 - 4 sporophytes (vs to 8 - 10 sporophytes); spores smaller (ca. 50 $70 \mathrm{mkm}$ ), with meshes of reticulations lower (vs larger, ca. (62)65 - 80 mkm usually, with meshes of reticulations high), etc.

Yamal plants of the subspecies are quite typical but have smaller thalli, only $3-5 \mathrm{~mm}$ wide (vs $10-15 \mathrm{mkm}$ in original description) that may be explained by unfavorable conditions of soil nourishment (the other basiphilous species in Yamal are smaller also). The spores are a little smaller too, 45 $60 \mathrm{mkm}$.

RICCIACEAE Reichenb. RiCCIA L.

Riccia sorocarpa Bisch. subsp. arctica Schust. (R. sorocarpa auct. non Bisch. - 
Andrejeva 1981)

ST. Er'yoha 1 .

In willow-moss spotty tundra on loam with Jungermannia polaris, J. obovata, Fossombronia alaskana, Cephaloziella arctica, Blepharostoma trichophyllum var. brevirete. With mature capsules. Previously it was known only from Greenland (Schuster 1992b).
This taxon, according to Schuster (1.c.), differs from the type subspecies in arctic distribution, somewhat smaller spore size, usually $65-86(91) \mathrm{mkm}$ (in Yamal plants $(60) 68-75(82) \mathrm{mkm}$ ); wing margins of spores usually vestigial and locally developed only or lacking; areolae tending to slightly smaller, mostly ca. $5-8(10) \mathrm{mkm}$ in diam (in Yamal plants (4)5-8(9) mkm), etc.

\section{EXCluded TAXA}

Erroneous identification

Barbilophozia attenuata (Mart.) Loeske

Cephalozia affinis Steph.

Chiloscyphus pallescens (Ehrh. ex Eoffm.) Dum.

Plagiochila arctica Bryhn \& Kaal.

Scapania brevicaulis Tayl.

Scapania lingulata Buch

\section{Corrected identification}

\author{
B. binsteadii \\ c. Iunulifolia \\ Ch fragilis \\ P. asplenioides subsp. porelloides \\ S. hyperborea (S. helvetica phenotypes). \\ spparently a small form of Scapania sect. Irrigua
}

\section{LITERATURE CITED}

AFONINA, O. M. \& J. DUDA [АФOHИНА, O. М. \& Й. [У ДА] 1983. Contributions to the flora of hepatics of Anudyr River Basin. - [Maтериand $x$ фnope печеночных мхов бассейна рекн Анадырь]. Norasti Sist. Nizsh. Rast. [Hoвосmu cucm. ruзш. pacm. ] 20: 182-190.

ANDREJEVA, E. N. [AHДPEEBA, E. H.] 1981. On some main types of habitats of bryophytes in southem hypoarctic tundras of Yamal. - 10 нехоторых осиовных типах местообитаний мохообразных в южных ппоартических тундрах Ямала]. - In. Schljakov, $R$ N. (ed.) Briolikhenologicheskie issledovaniya vysokogornykh raionov $i$ Severa SSSR, Apatity IB $\mathrm{KH}$ : Бриолихенологические 'исследомания sысокогорных районов и Севера СССР, (ред. IIIsaxळ P. H.), Anamumbi: 18-19.

ARNELL, H. W. 1918. Die Moose der Vega-Expedition. - Ark. Bot. 15(5): 1-111.

ARNELL, S. 1947. Contributions to the knowledge of the hepatics of Novaya Zemlya. - Srensk Bot. Tidskr. $41(2): 209-217$.

ARNELL, S. 1956. Iilustrated Moss Flora of Fennoscandis. I. Hepaticae. Lund: Gleerups, 314.

CZERNYADJEVA, 1. V. \& A. D. POTEMKIN [ЧЕРНЯДЬЕВА, И. В., А. Д. ПОТЕМКИН] 1993. On the bryophyte flora of the Central Yamal. - [K флоре мохообразных Центрального Ямала]. - Novasti Sist. Nizsh. Rast. [Hosocmu cucm. низи. pacm.] 29: 165-172.

DAMSHOLT, K. 1982. The perianth of Tritomaria quinquedentata var. turgida (Lindb.) Weim. (Hepaticae). - Bryologist 85(1):96-98.

GRIBOVA, S. A \& A. D. POTEMKIN [ГPИБOBA, C. А., А. Д. ПОТЕМКИН] 1988. On the hepatic flora of the Interfluve of Tomboy-Yakha and Se-Yakha Rivers (the Central Yamal). - [K флope печеночных мхов междуречья рех Томбой-яха и Cе-sхха (Центральный Ямал)]. Bot. Zhurn. [Bom. хурн.] $73(5): 685-690$.

INOUE, H. 1957. Notes on the taxonomical status of Lophozia diversiloba. - Bot. Mag. (Tokyo) 70: 357362.

INOUE, H. 1961 (1960). A new genus Hattoriella of the Lophoziaceae. - J. Hattori Bot. Lab. 23: 37-40.

KONSTANTINOVA, N. A. A. D. POTEMKIN \& R. N. SCHIJAKOV 1992. Check-list of the Hepaticae and Anthocerotae of the former USSR. - Arctoa 1(1-2): 87-127.

KOPONEN, T., P. ISOVIITA \& T. LAMMES 1977. The bryophytes of Finland: an annotated checklist. Flora Fennica 6: $1-77$.

LADYZHENSKAJA, K, I. \{C. I.\} [ЛАДЫХЖЕНСКАЯ, K. И.) 1971. New localities of a little-known species Pseudolepicolea fryei (Pers.) Grolle \& Ando in Soviet Arctic. - [O ножых местонахохдениях малонзиестното вида Pseudolepicolea fryei (Perss.) Grolle \& Ando в Coветской Apктике]. Nowosti Sist. Nizsh Rast. [Hosocmu cucm. rusu. pacm.] 8: 314-317.

MACVICAR, S. M. 1926. The student's handbook of British hepatics. 2nd ed. Eastbourne, 493.

MOGENSEN, G. S. \& G. R. BRASSARD 1978. Fossombronia alaskana found in Greeniand. Bryologist 81 (1): 155.

MUELLER, K. 1956. Die Lebermoose Europas (Musci hepatici). U. 1-9. - In. Rabenhorst's KryptogamenFlora wo Deutschland, Oesterreich u.d. Schweiz. Leipzig, 6(3), 1365. 
PERSSON, H. 1946. Some Alaskan and Yukon bryophytes. - Bryologist 49 (2): 41-58.

POTEMKIN, A. С. [ПОTЕMКИН, А. Д.] 1988. On the liverworts of the Yamal arctic tundras. - [O печеночних мхах арктических тундр Ямала]. Труды 2 мал конф. ботаников Ленинграда, Ч. I. Ленинград, апр. 1988. Л., АН СССР, Боm. Hн-m. Дen. ВИНИТИ I4.VII.1988, $N^{\circ}$ 5682-B88 /Trudy 2 molod. conf. bot. Leningrada, Pt. I. Leningrad, Apr. 1988. Leningrad, Akad. Nauk SSSR, Bot. Inst. Msc. Reserved VINITI 14.VII.1988, No 5682B88] 1: 235-255.

POTEMKIN, A. D. (POTYOMKIN] [HOTEMKUH, A. L.] 1989. Liverworts of the Yamal arctic tundras.[Печеночные мхи арктических тундр Ямала]. Bot. Zhurn. [Боm. журн.] 74(6): 806-815.

POTEMKIN, А. D. [IIOTEMKИН, А. Д.] 1990a. On the variation of some hepatics from southern and arctic tundras of the Yamal Peninsula. - [06 изменчивости нехоторнх печеночных мхов из южных и арктичесхих тундр патуострова Змал]. Nowasti Sist. Nizsh. Rast. [Hosacmu cucm. nusu. pacm. ] 27: 147-153.

[РОTEMKIN, А. D.] ПОТЕМКИН, А. Д. $1990 \mathrm{~b}$. Анализ модифнкацнонной измекчивости печеночных мхов полуострова Ямал. - [Analysis of modificational variability of hepatics of Yamal Peninsulal. Tpydu 3 мол конф. ботаников Ленинграда, У. I. Ленинград, апр. 1990. Л., АH СССР, Бот. Ин-т. Деп. ВННИТИ 14. ХI. 1990, No 5700-B90 ITrudy 3 molod. conf. bot. Leningrada, Pt. I. Leningrad, Apr. 1990. Leningrad, Akad. Naut SSSR, Bot. Inst. Msc. Reserved VINITI 14. XI. 1990, No 5700-B90/ 1: 235-255.

POTEMKIN, A. D. [ПОТЕМКИН, А. Д.] $1990 \mathrm{c}$. Lophozia alboviridis and $L$ decolorans (Hepaticae) on the Yamal Peninsula. - [Lophozia alboviridis L. decolorans (Hepaticae) на Ямฌлe]. Bot. Zhurn. [Бот. журн.] 75(8): 1086-1092.

POTEMKIN, A. D. [ПОTEMKИН, А. Д.] 1990d. The genus Tritomaria (Lophoziaceae, Hepaticae) in Yamal. - [Род Tritomaria (Lophoziaceae, Hepaticae) на Ямале]. Bot. Zhurn. [Fom хурн] $75(12): 1742-1753$.

POTEMKIN, A. D. 1990. The liverworts of the Yamal tundras. - In. Schljakov, R.N. (ed.) Abstr. 7th Meeting CEBWG. Kirows, 54-55.

POTEMKIN, А. D. [IIOTEMKHН, А. Д.] 1991. On the present state of understanding and prospects of studying of the family Aneuraceae in the USSR. [0 состояния изученности и задачах по изучению семейства Aneuraceae в CCCP]. In: Demkiv, O.T. (ed.) Eriologia $v$ SSSR, ee dastizheniya i perspektivy. Lwov, Akad. Nauk SSSR \& Akad. Nauk Ukr. SSR. IB KH: Bpuorozus a СССР, eе достихения $u$ nерспективы (ред. Демкия O.T.), ЛЬеов, АН СССР, АH УССРI: $169-174$.

POTEMKIN, А. D. [ПОТЕМКИН, А. Д.] $1992 \mathrm{a}$. Barbilophozia hyperborea (Schust.) Poteak. comb. nov. and Cephaloziella rubella (Nees) Warnst. var. arctogena Schust. in Sovet Arctic. - [Barbilophozia hyperborea (Schust.) Potemk. comb. nov. и Cephaloziella rubella (Nees) Warnst. var. arctogena Schust. в Coветской Арктике]. Nowosti Sist. Nizsh.
Rast. (Hosocinu cucm rusus. pacm / 28: 148-155.

POTEMKIN, A. D. 1992b. A new species of Prasarithus (Hepaticae, Gymnomitriaceae) from the Yamal Peninsula, West Siberian Arctic. - Ann. Bot. Fennici 29(4): 319-323.

POTEMKIN, A. D. [ПоTEMKИН, А. Д.] 1993a. On the infraspecific taxonomy, reproduction and synonymy of Scapania scandica (H.Arn. et Buch) Macv. (on the base of the Yamal materials). - IO внутривидовой тахсономии, размножении и синонимике Scapania scandica (H. Am. et Buch) Macv. (по ямальским матерналам)]. Novasti Sist. Nizsh. Rast. [Hosocmu cucm. нuзu. pacm] 29: 153-157.

FUIEMKIN, А. D. [ПОТЕМКИН, А. Д.] 19936. On the reproduction of some hepatics. - IO размножекии нехоторьх печеночников]. Novosti Sist. Nizsh. Rast. [Hosocmu cucm. кuзu. pacm.] 29: 145-152.

POTEMKIN, A. D. \& I. $V$. TCHEREPANOV [ПОТЕМКИН, А. Д., И. В. ЧЕРЕПАНОВ] 1993. On the hepatic flora of the Leningrad Province. New and little-known taxa for the province. - [K фrope печеночных мхов Лениградской области. Новые и малонзвестные для облстн таксоны]. Novasti Sist. Nizsh. Rast. [Hosocmu cucm. rusue pacm.] 29: 158-165.

REBRISTAYA, O. V. [РЕБРИCTAG, O. В.] 1989. Peculiarities of plant cover of the Yamal Peninsula. [Особенности растительного покрова полуострова Ямал]. In. Shilov, V.N. (ed.) Kharakteristiko geologicheskikh $i$ pochuenno-rastitelnykh asobennastej territorij gazokondensatnykh mestorozhdenij severa Tyumenskoj oblasti. Moscow. IB кн.: Характеристиха геологических и почвенно растительных особенностей территорий газоконденсатньх месторохедений севера Тюменской области (ред. ШІилов, В.Н.), M., ]:40-47.

SCHLJAKOV, R. N. [யLЛЯKOB, P. H.] 1973. Systematic notes on the family Lophoziaceae Cavers. - [Систематические заметки по семейству Lophoziaceae Cavers]. Nowasti Sist. Nizsh Rast. [Hoeocmu cucm. rusu. pacm.] 10: 287-.302.

SCHLJAKOV, R. N. [UJLGKOB, P. H.] 1980-1981. The hepatics of the North of the USSR. [Печеночные мхи Севера CСCP]. Leningrad, Nauka [J., Hayka] 3, 190 (1980); 4, 221 (1981).

SCHUSTER, R. M. 1969-1992. The Hepaticae and Anthocerotae of North America east of the hundredth meridian. - New York-London, Columbia Univ. Press 2, 1062 (1969); 3, 880 (1974); 4, 1334 (1980); - Chicago, Field Mus. Nat. Hist. 5, 854 (1992a); 6, 937 (1992b).

SCHUSTER, R. M. 1987. Studies on Metzgeriales. I. North Amarican Aneuraceae. - J. Hattori Bot. Lab. 62: 299-329.

SCHUSTER, R. M. 1988. The Hepaticae of South Greenland. - Nova Hedwigia Beih 92: 1-255.

SCHUSTER, R. M. \& K. DAMSHOLT 1974. The Hepaticae of West Greenland from ca. $66 \mathrm{~N}$ to 72 N. - Medd. Groenland 199(1): 1-373.

SCHUSTER, R. M., W. C. STEERE \& J. W. THOMSON 1959. The terrestrial Cryptogams of Northern 
Ellesmere Island. - Nath. Mus. Canada Bull. 164: 1132.

SISKO, R. K. [СИСКO, P. K.] 1977. Introduction. [Введение]. In. Sisko, R.K. (ed.) YamaloGydanskaya oblast: Leningrad: Gidrometeoizdat (B кн.: Ямало-Гыdанская область (ред. Сиско, P.K.), Л., Гидрометеоиздат ]: 4-8.

STEERE, W. C. \& H. INOUE 1974. Fassombronia alaskana, a new hepatic from Arctic Alaska. Bryologist 77(1): 63-71.

STEERE, W. C. \& H. INOUE 1978. The Hepaticae of Arctic Alaska. - J. Hattori Bot. Lab. 44: 251-315.

YURTSEV, B. A., A. I. TOLMACHEV \& 0 . V. REBRISTAYA [ЮРЦEB, Б. А., А. И. TOЛMAYEB \& O. B. РЕБРИСТАЯ] 1978. The floristic delimitation and subdivision of the Arctic. [Флористическое ограничение и разделение Арктики]. In: Yurtsev, B.A. (ed.) Arkticheskaya floristicheskaya oblast: Leningrad, Nauka lB $\mathrm{KH}$ : Арктическая флористическая область (ред. Юрцев Б.A.), Л.: Наука] 9-67.
ZHUKOVA, A. L. \& O. V. REBRISTAYA [ЖYKOBA, А. Л. \& О. В. РЕБРИСТАЯ] 1986. On the liverwort flora of the Matyuiyakha River Region (Yamal Peninsula). - [K флоре печеночных мхов района реки Матюйяхи (полуостров Ямал)]. Bot. Zhurn. (Бот. хурн.] $71(5):$ 642-649.

ZHUKOVA, A. L. \& $0 . \quad$ V. REBRISTAYA \{REBRISTAJA] [ЖYKOBA, A. Л. \& O. B. РЕБРИСТАЯ] 1987. On the hepatic flora of Belyy Island (Kara Sea). - [K флоре печеночных мхов острова Белого (Карское море)]. Nowosti Sist. Nizsh Rast. [Hosocmu cucm. жuзu. pacm.] 24: 208-2/3.

ZINOVIEVA, L. A. [ЗИНOBЬEBA, Л. A.] 1969. Sphenolobus cavifolius (Buch \& Arn.) K. Muell. and Sphenolobus minutus (Crantz) Steph. on the base of the Ural materials (morphologic and systematic notes). - [Sphenolobus cavifolius (Buch \& Arn.) K. Muell. и Sphenolobus minutus (Crantz) Steph. no уральским материалам (морфологосистематические заметки)]. Uchenye zapiski Permskogo Gos. Univ. [Ученые записки Перм. Го. УН--та] 179: 282-288. 